\title{
Immunological Response to Haemonchus contortus Antigen in Peripheral Blood Mononuclear Cells of Parasite Resistant and Susceptible Sheep
}

Jesica Rae Jacobs

Follow this and additional works at: https://researchrepository.wvu.edu/etd

\section{Recommended Citation}

Jacobs, Jesica Rae, "Immunological Response to Haemonchus contortus Antigen in Peripheral Blood Mononuclear Cells of Parasite Resistant and Susceptible Sheep" (2016). Graduate Theses, Dissertations, and Problem Reports. 5871.

https://researchrepository.wvu.edu/etd/5871

This Dissertation is protected by copyright and/or related rights. It has been brought to you by the The Research Repository @ WVU with permission from the rights-holder(s). You are free to use this Dissertation in any way that is permitted by the copyright and related rights legislation that applies to your use. For other uses you must obtain permission from the rights-holder(s) directly, unless additional rights are indicated by a Creative Commons license in the record and/ or on the work itself. This Dissertation has been accepted for inclusion in WVU Graduate Theses, Dissertations, and Problem Reports collection by an authorized administrator of The Research Repository @ WVU.

For more information, please contact researchrepository@mail.wvu.edu. 
Immunological Response to Haemonchus contortus Antigen in Peripheral Blood Mononuclear Cells of Parasite Resistant and Susceptible Sheep

\author{
Jesica Rae Jacobs
}

Dissertation submitted to the Davis College of Agriculture, Natural Resources and Design at West Virginia University in partial fulfillment of the requirements for the degree of

Doctor of Philosophy in Animal and Food Science

\author{
Scott Bowdridge, Ph.D., Chair \\ Vagner Benedito, Ph.D. \\ Christopher Cuff, Ph.D. \\ Robert Taylor, Ph.D. \\ Anne Zajac, DVM, Ph.D.
}

Division of Animal and Nutritional Sciences

Morgantown, West Virginia

2016

Keywords: Haemonchus contortus, peripheral blood mononuclear cells, gene expression, RNA-Seq

Copyright 2016 Jesica Rae Jacobs 


\title{
Abstract \\ Immunological Response to Haemonchus contortus Antigen in Peripheral Blood Mononuclear Cells of Parasite Resistant and Susceptible Sheep
}

\author{
Jesica Rae Jacobs
}

Parasitism by Haemonchus contortus is the greatest concern of sheep producers and results in billions of dollars in economic loss each year. St. Croix hair sheep are naturally resistant to $H$. contortus infection, but have body characteristics which are unfavorable for production. Resistance to $\mathrm{H}$. contortus is immune mediated; characterized by a $\mathrm{T}$ helper type 2 (Th2) response, however the mechanism of the development of immune response is not known. In these studies, immunological responses of parasite resistant St. Croix sheep and Suffolk sheep peripheral blood mononuclear cells (PBMC) are evaluated in response to $H$. contortus antigens. Three uninfected $H$. contortus primed St. Croix sheep and three uninfected $H$. contortus primed Suffolk sheep were used to collect PBMC. PBMC were cultured in vitro with $H$. contortus crude larval antigen (CLA) or crude worm antigen (CWA) for varying amounts of time. Cell culture supernatants were collected for cytokine evaluation by ELISA and RNA was extracted from cells for analysis by qPCR or RNA-Sequencing. Cytokine ELISA revealed PBMC from St. Croix produce greater amounts of interleukin-4 (IL-4), the characteristic cytokine required for and produced by Th2 cells, then Suffolk PBMC exposed to CLA. St. Croix sheep generated appreciable IL-4 by 6 hours of culture with CLA, while Suffolk PBMC did not generate IL4 until 72 hours of culture with CLA. Analysis by qPCR showed St. Croix PBMC upregulated mRNA for the IL-4 receptor (IL4Ra), and other key Th2 genes IL-13, IL-5 and MRC1 after 6 hours of culture with CLA. Suffolk PBMC showed downregulated IL4Ra and no upregulation of Th2 genes at 6 hours of culture with CLA. RNA-Sequencing revealed St. Croix PBMC upregulate 499 genes in response to 6 hour of culture with CLA, while 130 genes were upregulated in Suffolk PBMC. Increases in genes associated with inflammation, antigen recognition, immune response and function in antigen presenting cells may contribute to the ability of St. Croix to resistance infection by $H$. contortus. 


\section{Acknowledgements}

I would firstly like to thank the entire faculty and staff of the Division of Animal and Nutritional Sciences at West Virginia University. The personnel employed in this division share a genuine interest and willingness to assist students throughout their collegiate journeys. I am grateful for the privilege of completing two graduate degrees among faculty with open door policies and a desire to see everyone succeed and staff who go the extra mile. A special thank you goes to Dr. Robert L. Taylor, Jr., who displays is always happy to help troubleshoot an issue, provide a new way of looking at a problem and genuinely cares about students on a personal level, all while running the Division.

Research is not conducted in a vacuum or without significant contribution of others. Having the reliable and willing support of fellow graduate students makes a world of difference. Throughout my 5 years of study at WVU, many graduate students have risen to the occasion of working together to get the best result. If ever I needed someone to check my math, help approach a problem, brainstorm with me or just take a break, I could always lean on people like Lizzie Bowdridge, Taylor Harrison, Jessalyn Hadfield, Brian Glover, John Boney and Elizabeth Shepherd; all of whom exemplify the hard work and dedication required to be successful graduate students.

Dr. Scott Bowdridge not only invited me into his lab as his first graduate student, he made me feel like part of his family. Dr. Bowdridge showed me exactly what it means to work hard and always take the extra step. If ever I thought I couldn't do something, Dr. Bowdridge's assurance that he believed I could gave me the confidence to move forward. I will be endlessly grateful for Dr. Bowdridge's decision to accept me as a graduate student in his lab and taking the time to train and challenge me.

Finally, I would like to offer my thanks to my family for their unwavering support in my graduate endeavor. My parents, Brian and Brenda, were always there, without fail, encouraging me to move forward. Without them, none of this would have been possible. 


\section{Table of Contents}

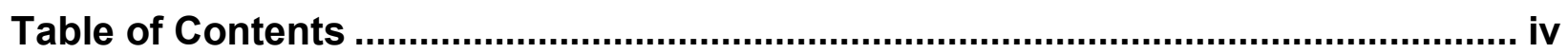

Chapter 1: Literature Review ............................................................................ 1

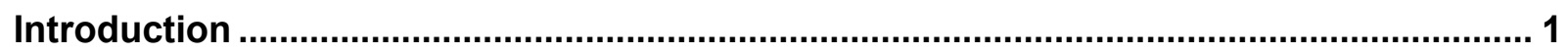

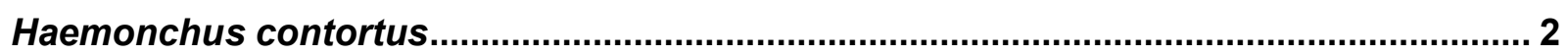

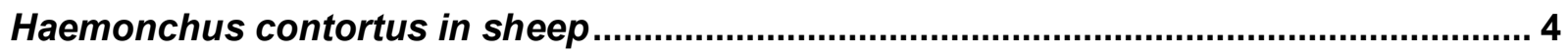

Anthelminthic Resistance in Haemonchus contortus ................................................... 6

St. Croix Resistance to Haemonchus contortus........................................................... 8

Parasite Resistance is Immune Mediated ................................................................... 9

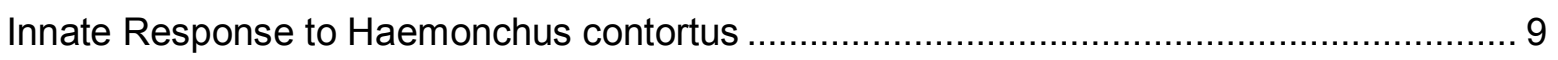

Adaptive immune response to Haemonchus contortus ................................................ 16

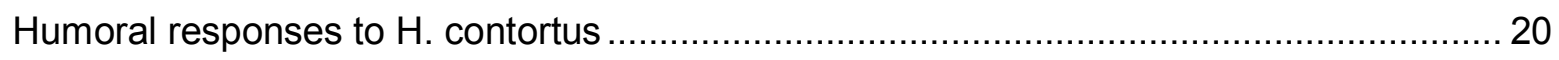

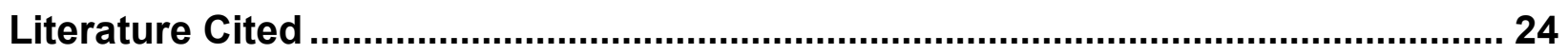

Chapter 2: Effects of culturing ovine PBMC with Haemonchus contortus antigen

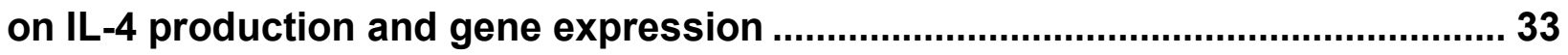

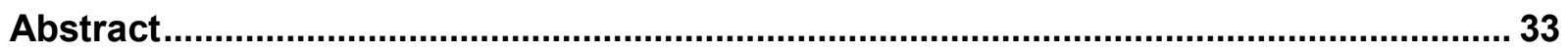

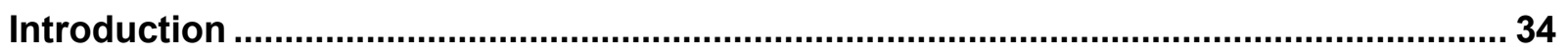

Materials and Methods …..................................................................................... 35

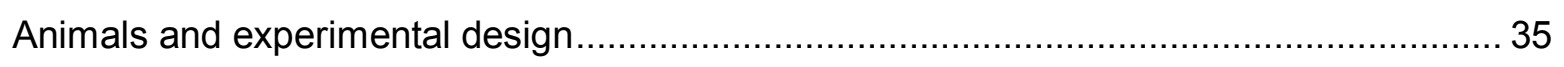

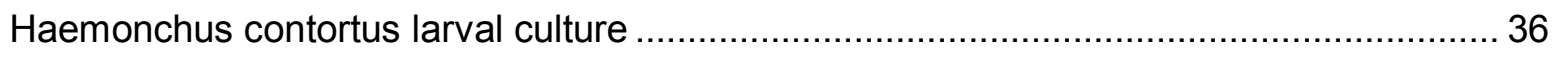

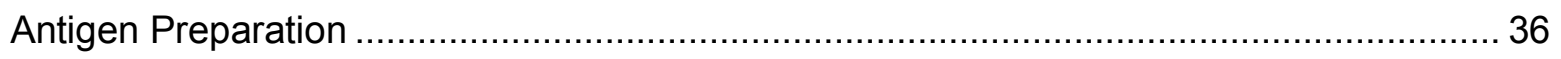

Peripheral blood mononuclear cell separation ............................................................... 37

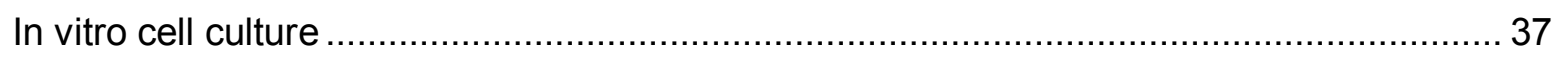




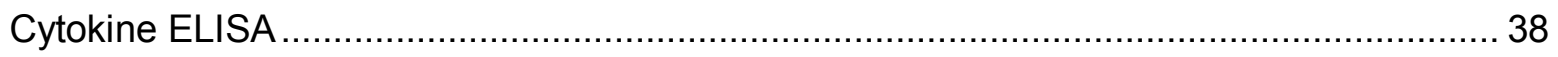

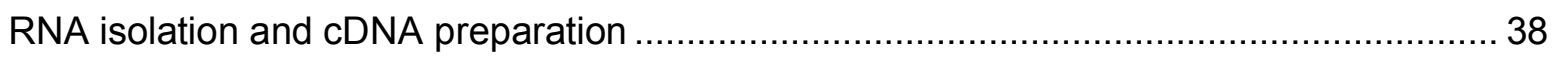

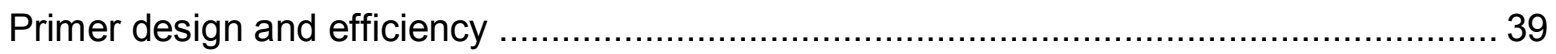

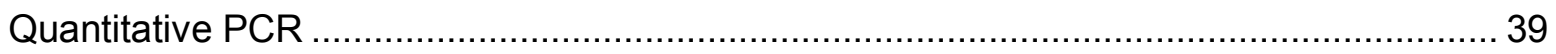

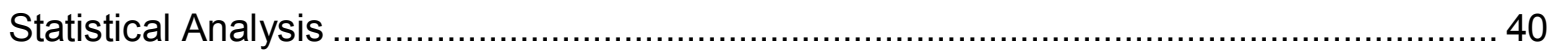

Results

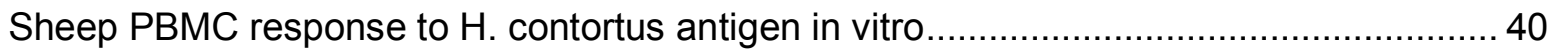

Gene expression of sheep PBMC exposed to crude larval antigen ................................ 42

Exogenous supplementation of Suffolk PBMC with IL-4 protein ...................................... 43

Pharmacological inhibition of STAT6 in St. Croix PBMC cultured with H. contortus crude

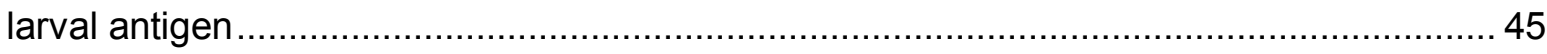

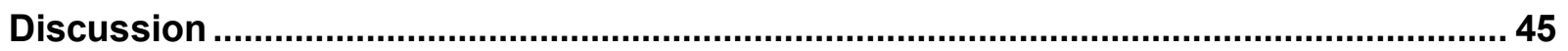

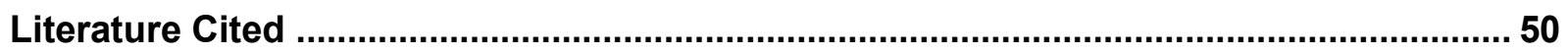

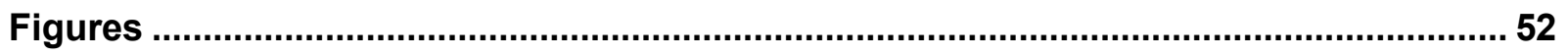

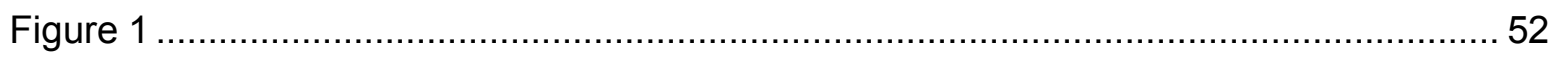

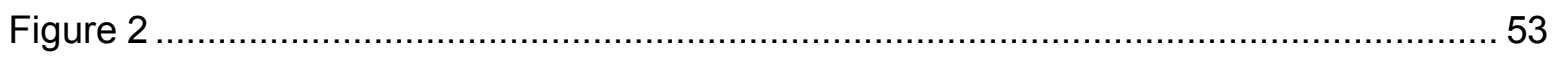

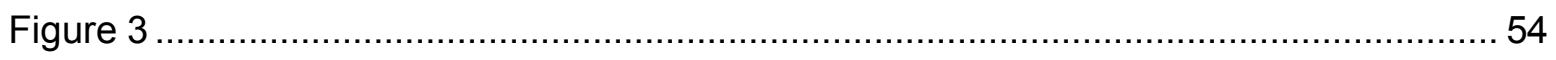

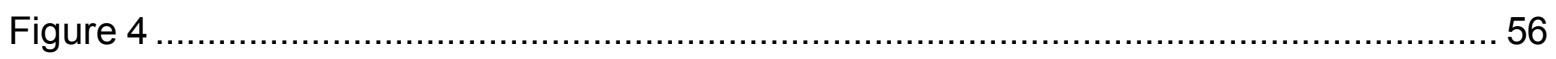

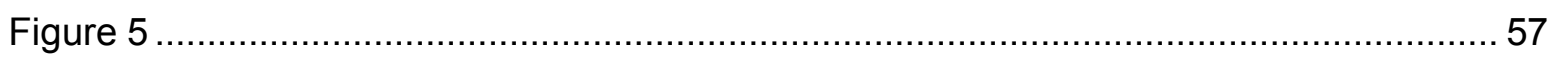

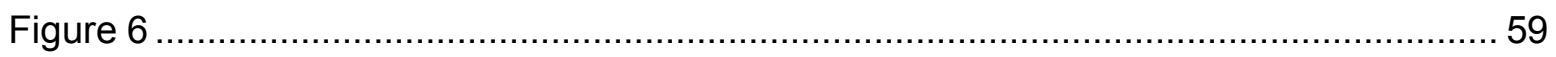

Chapter 3: RNA-Sequencing of PBMC derived from parasite resistant and susceptible sheep reveal differential gene expression after exposure to $H$.

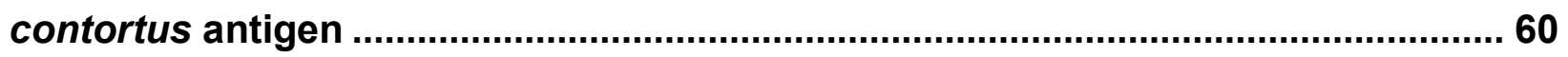

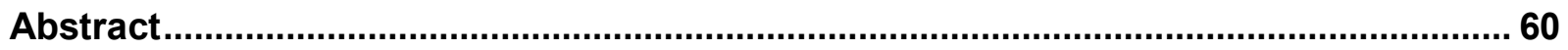

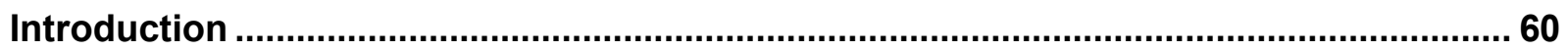




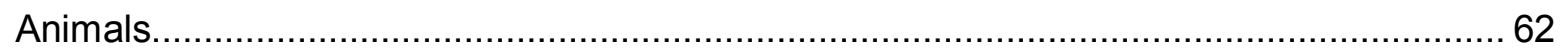

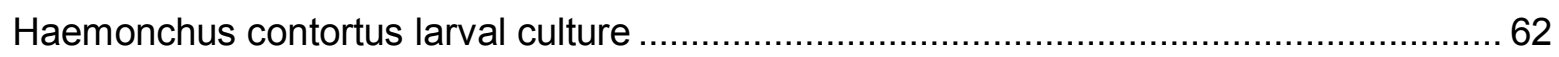

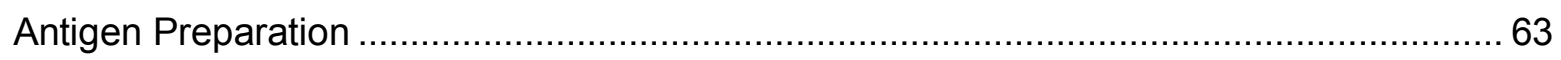

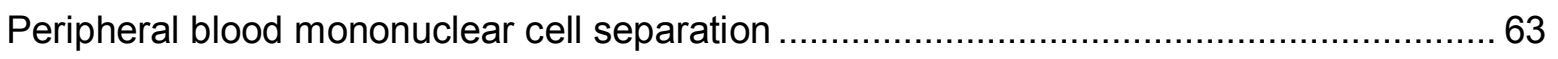

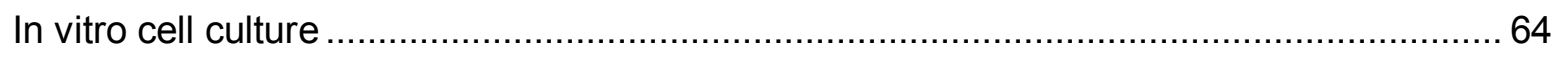

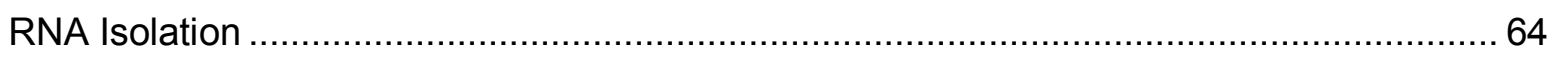

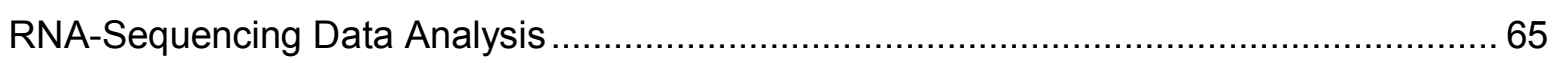

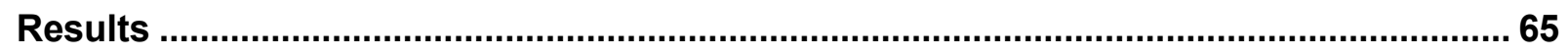

CLA treatment changes genetic profile of PBMC in St. Croix and Suffolk sheep .............. 65

St. Croix PBMC upregulate more genes in response to $\mathrm{H}$. contortus larval antigen culture

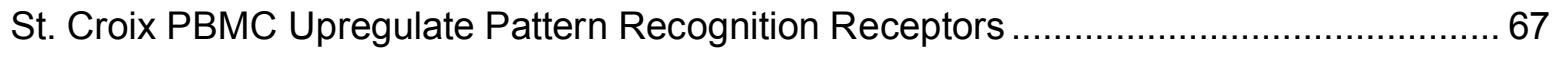

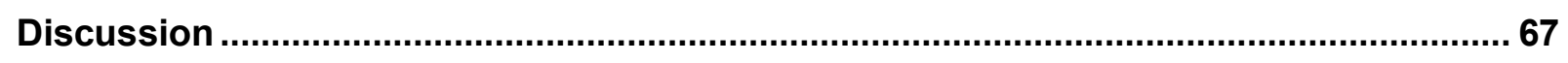

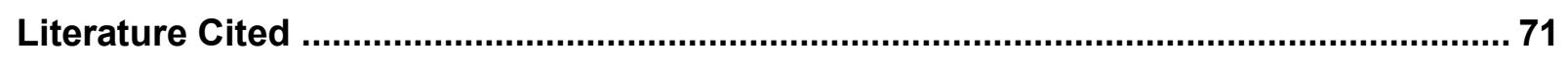

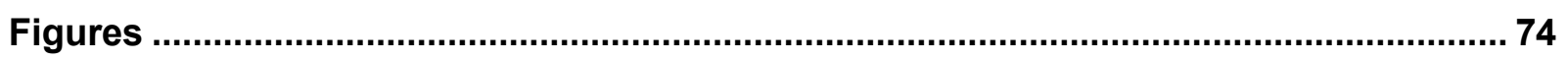

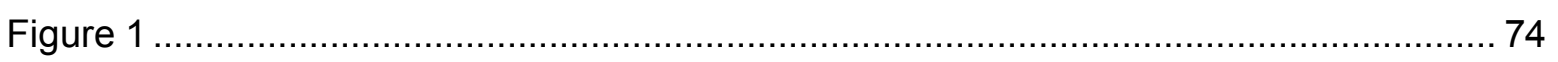

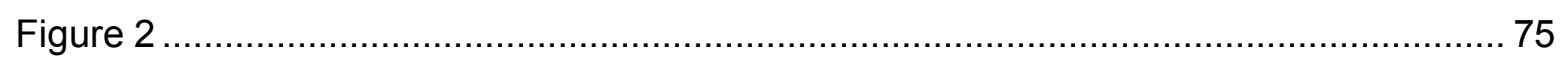

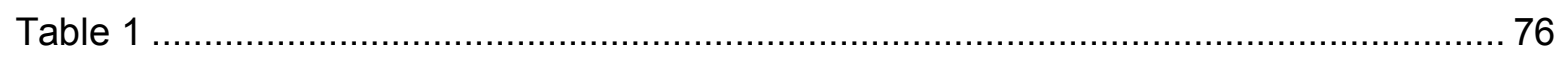

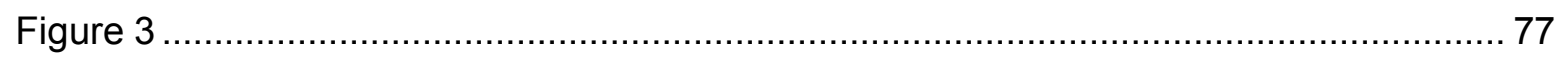

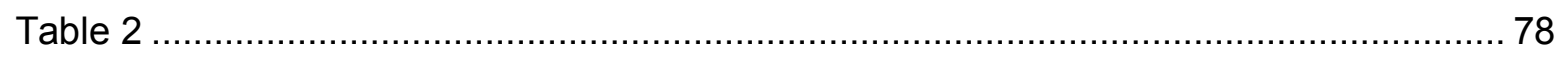

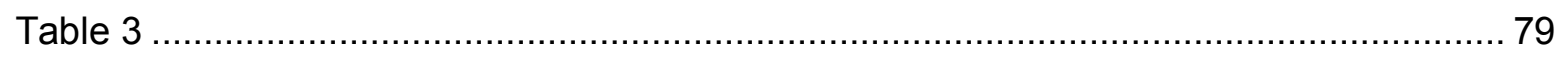

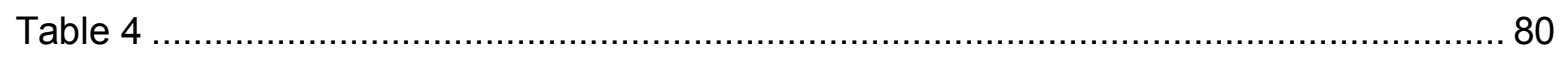

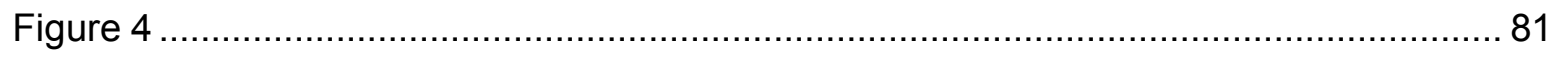

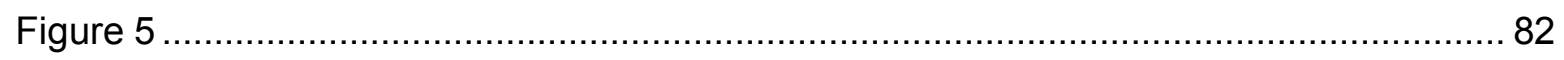

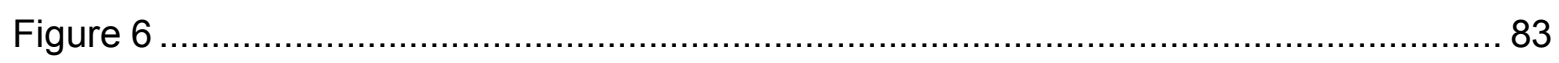




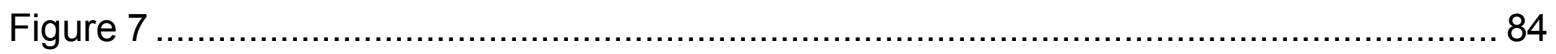

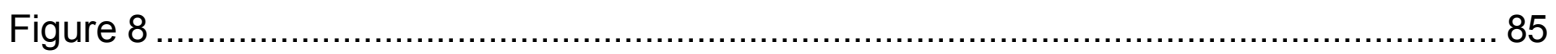

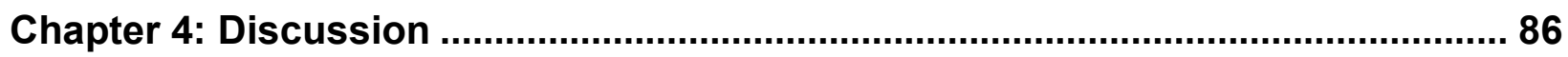

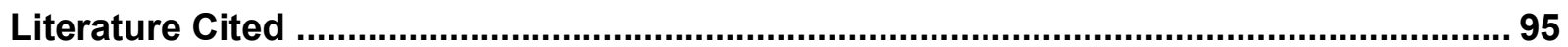

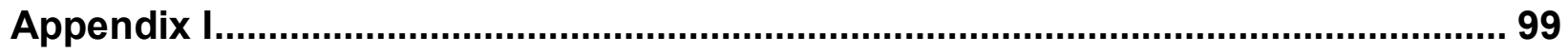

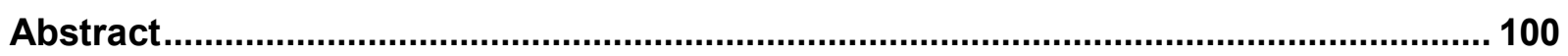

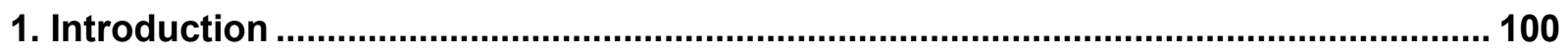

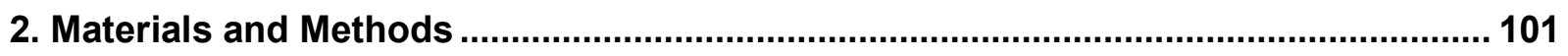

2.1 Maintaining Haemonchus contortus-naïve lambs .................................................. 101

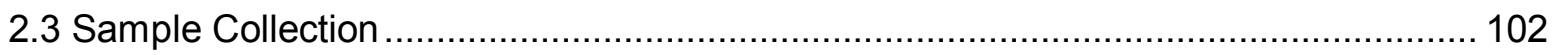

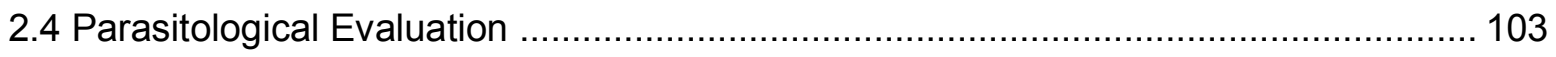

2.4.1 Haemonchus contortus larval culture ............................................................. 103

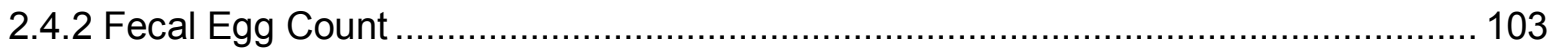

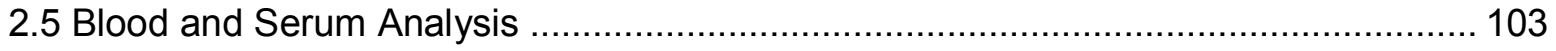

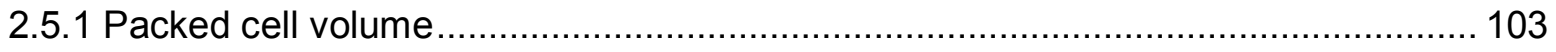

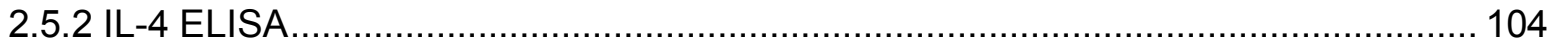

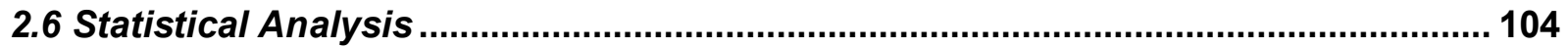

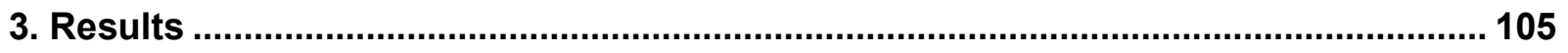

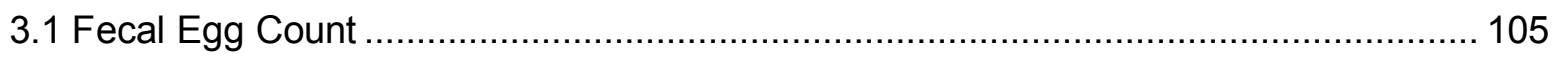

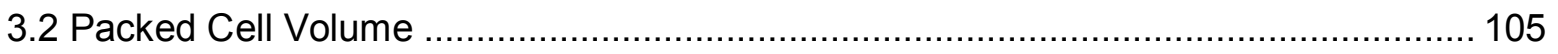

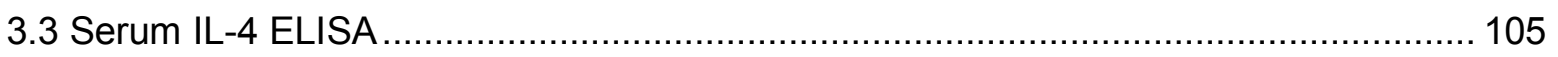

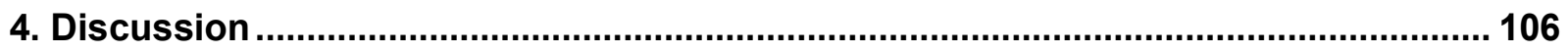

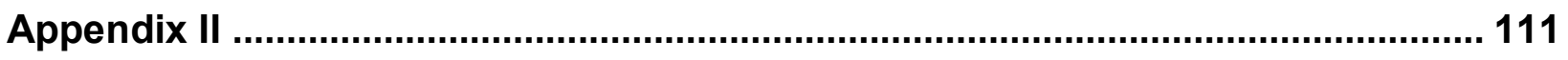

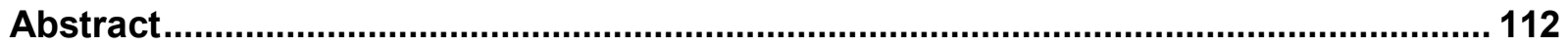

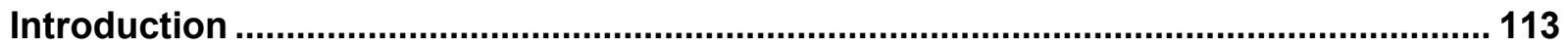




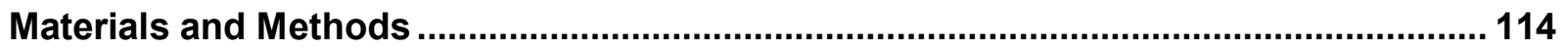

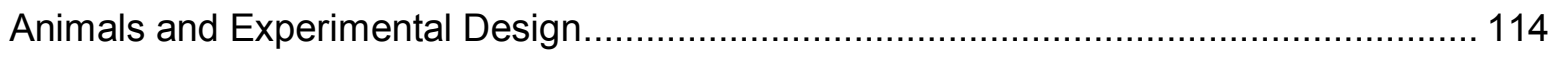

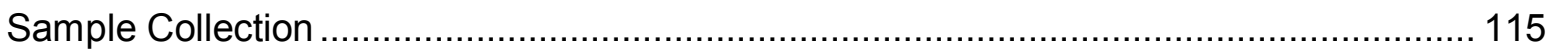

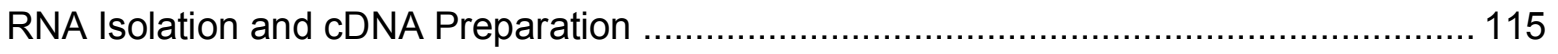

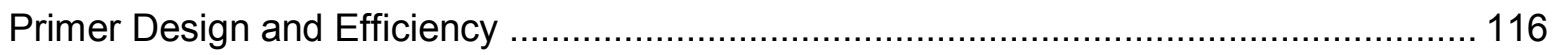

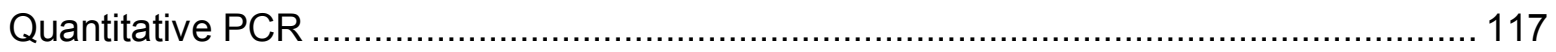

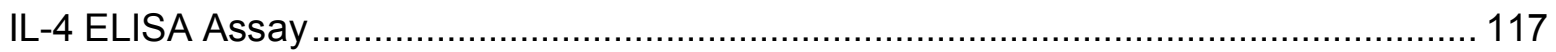

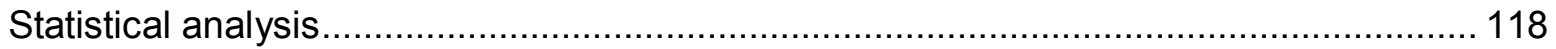

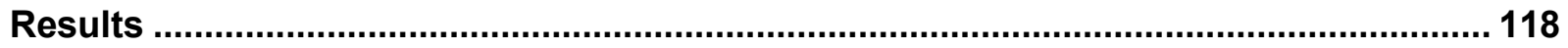

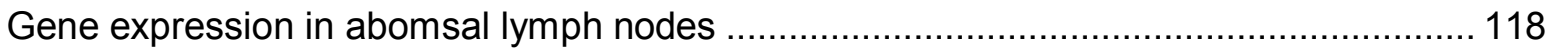

Gene expression in full-thickness abomasal tissue ..................................................... 118

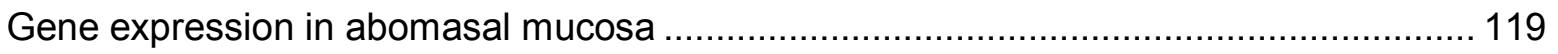

Circulating serum IL-4

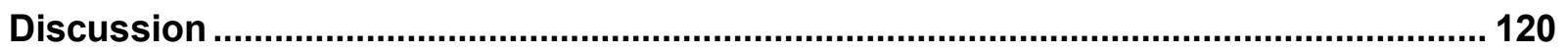

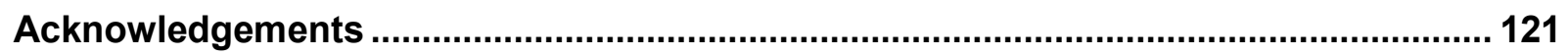

References

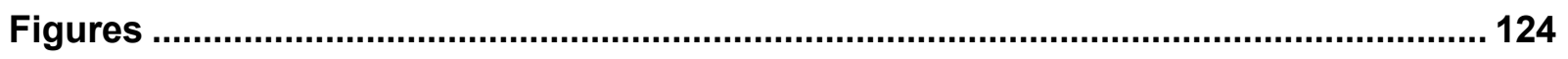

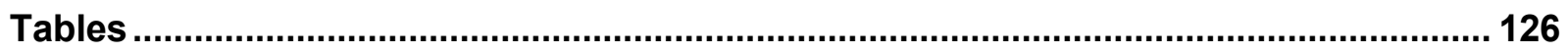




\section{Chapter 1: Literature Review}

\section{Introduction}

Sheep production has major impacts on food and textile supplies worldwide. In 2015, 14 million tons of lamb were projected to be produced (FAO, 2015) and 1,130.9 mkg of wool was produced in 2014 (Wool Report, 2014). Meeting global demand for sheep products is dependent on sheep health. Sheep that experience disease typically have reduced average daily gain (Daniel and Held, 2006) as biological energy is shifted from growth to fighting disease. According to a USDA animal health report, the most prevalent health concern among sheep operations in the United States was gastrointestinal nematode infection (USDA, 2001). Annual economic loss due to gastrointestinal parasites in Australia alone is reported to be 1 billion dollars and global impact is estimated to be approximately tens of billions (Roeber et al., 2013).

The most concerning gastrointestinal parasite to sheep producers is Haemonchus contortus. Haemonchus contortus is a nematode parasite of the Trichostrongylidae family, it feeds on blood and is common in ruminant hosts. While large ruminants can harbor this parasite, its effects are greatest in small ruminants. Parasitism by $\mathrm{H}$. contortus causes anemia, hypoproteinemia, lack of growth and can lead to sudden death. Anthelminthic drugs have been developed to treat gastrointestinal nematodes, including $H$. contortus, however due to extreme overuse, $H$. contortus has become resistant to all classes of drugs available (Howell et al., 2008). Widespread anthelminthic resistance has created a need for alternative methods of $H$. contortus control. 
St. Croix hair sheep are known to have natural resistance to $H$. contortus (Courtney et al., 1985, Gamble and Zajac, 1992). Though naturally parasite resistant, St. Croix sheep are not a desirable production breed. St. Croix hair sheep have low carcass weights, are slow to reach maturity and are devoid of wool (Ockerman et al., 1982). As such, St. Croix hair sheep are not viable for production use, however are a key breed in understand parasite resistance in sheep. Alternatively, the most common breeds of sheep found in United States sheep production are black-faced breeds, such as Suffolk (USDA, 2011), which are highly parasite susceptible.

Resistance to $H$. contortus in St. Croix sheep has been associated with immune response (MacKinnon et al., 2010). Further, effective immune response to $H$. contortus has been characterized as a T helper type 2 (Th2) response (LaCroux et al., 2006). St. Croix sheep have been observed to have a more robust and timely generation of immune development in response to $H$. contortus (Bowdridge et al., 2013; Bowdridge et al., 2015; Jacobs et al., 2015 [Appendix I]). Differential immune response by resistant and susceptible breeds has been observed (MacKinnon et al., 2009), the mechanism controlling disparate timing and activation between breeds is not known. Therefore, the aim of these studies was to discover underlying mechanisms of differential immune activation between parasite resistant St. Croix and parasite susceptible Suffolk sheep in response to $H$. contortus.

\section{Haemonchus contortus}

Haemonchus contortus has a very simple life cycle, much like most members of the Trichostrongylidae family. Eggs from gravid adult females are shed in the feces. In the environment, eggs continue to develop through three larval stages. Larvae are 
capable of infecting hosts in the third larval ( $\left.\mathrm{L}_{3}\right)$ stage. Third stage larvae become encapsulated in moisture droplets, which move up or down vegetation based on cohesion. Hosts become infected upon ingesting $L_{3}$ larvae from pastures while grazing. After ingestion, $L_{3}$ larvae travel to the abomasum of the ruminant digestive tract. At this point, larvae go through a final larval stage where they begin to feed on blood. Haemonchus contortus possess a lancet, which is used to penetrate the abomasal wall, after which, worms are able to feed on blood passing by the mouth. Larvae further develop into the adult stage, in which they are able to sexually reproduce and the females will begin to shed eggs. Female $H$. contortus adults are capable of passing 5,000 eggs each day. Eggs are shed through the feces of the host and the cycle continues. Completion of the $H$. contortus life cycle takes $17-21$ days.

Haemonchus contortus are active during warm, humid summer months, in the northern hemisphere. The largest threat to $H$. contortus viability is desiccation. In climates experiencing winter months, $H$. contortus is capable of hypobiosis. During hypobiosis, larvae do not develop past the $L_{4}$ larval stage and may remain in the alimentary mucosa, while adults may remain in the abomasum (Herd et al., 1983). Larvae and adults remain in hypobiosis until triggered by environmental cues. Triggers for ending hyobiosis are not completely understood, however fecal egg count rises in the spring in areas with temperate climates. Fecal egg count is also observed to increase two weeks prior to parturition and is increased for as long as 8 week follow parturition, which is known as "periparturient rise" (Crofton, 1954).

The largest concern associated with $H$. contortus infection in sheep is blood loss. A well-established $H$. contortus infection may deplete a lamb of $1 / 5^{\text {th }}$ of its circulating 
erythrocytes each day and one tenth of erythrocytes in adult sheep (Georgi and Whitlock, 1967). As packed cell volume (PCV) decreases, body condition of the animal decreases and causes the condition known as "haemonchosis". Haemonchosis is characterized by anemia, edema, lack of growth, poor wool and body condition and poor quality of life. Death occurs when blood loss by $H$. contortus exceeds the hematopoietic regenerative capability of the animal. Lack of growth, increased nutrition requirements, poor wool quality and death of animals are each sources of economic loss as a result of haemonchosis.

\section{Haemonchus contortus in sheep}

Sheep are commonly parasitized by a variety of gastrointestinal nematodes, but the helminth of greatest concern is $H$. contortus. Most grazing sheep are parasitized by $H$. contortus, however young, recently weaned lambs which may succumb to infection if large worm burdens are present. $H$. contortus infection is found throughout the world and has been documented to be responsible for $75 \%-100 \%$ of established worms gastrointestinal nematode populations in sheep (Kaplan, 2004).

Haemonchus contortus is sensitive to cold temperatures and desiccation, therefore hypobiosis may be a way to survive winter conditions. Worms are triggered by environmental cues to emerge from hypobiosis. The complete mechanism of emergence from hybobiosis is not fully understood, but suggested cues include photoperiod and hormonal changes within the host (Fleming and Gamble, 1993). Increases in H. contortus eggs found in sheep feces (fecal egg count, FEC) are correlated with the onset of spring, which is commonly referred to as "spring rise", giving credibility to photoperiod as an environmental trigger. Additionally, FEC has also be documented increasing for a period 
of 8 weeks following parturition, a phenomenon known as "periparturient rise" (Crofton, 1954), which corroborates host hormonal changes as a hypobiosis emergence cue. Parturition is also associated with a depression of immunity, which may contribute to susceptibility to $H$. contortus infection (Beasley et al., 2012).

If parasitized by $H$. contortus, adult sheep may lose $1 / 10$ of their total circulating erythrocytes in a day, while parasitized lambs may lose 1/5 of their erythrocytes (Georgi and Whitlock, 1967). Symptoms associated with haemonchosis may include anemia, weakness, lack of growth, poor body and wool conditions and / or death, depending on the level of parasitism. Pathology associated with haemonchosis may be evaluated by packed cell volume (PCV), which is a measurement of percentage of circulating red blood cells or measurement of plasma proteins. As PCV decreases, plasma volume increases in compensation. Increased plasma volume leads to hypovolemia and subsequent edema. Anemia may be evaluated on site by observing the pallor of ocular membranes using a standardized scale known as FAMACHA scoring, whereby animals may be assigned a score ranging from 1 (optimal redness) to 5 (very pale). If blood depletion due to $H$. contortus infection exceeds hematopoietic capacity, animals will succumb to death. Edema can be visualized in highly parasitized animals in the lower extremeties, such as lower legs and also in the jaw, resulting in a condition known as "bottle jaw," which is commonly associated with haemonchosis. Animals most susceptible to haemochosis are those suffering from poor body conditions or stress such as weaning or malnutrition.

Adult $H$. contortus reproduce sexually during the patent stage of infection and may release between 5,000 and 10,000 fertilized eggs each day, which are passed onto pastures through feces (Bowman, 2009). Upon passage in feces, eggs develop into 
larvae, thus completing the $H$. contortus life cycle, which may be completed in 21 days during optimal warm, humid conditions.

\section{Anthelminthic Resistance in Haemonchus contortus}

Three classes of anthelminthic drugs have been developed to treat $H$. contortus infection: benzimadazoles, macrocyclic lactones and imidazothiazoles. Benzimidazole compounds consist of a benzene ring and an imidazole (Barker et al., 1960). Members of the benzimidazole family used for de-worming include albendazole, fenbendazole and thiabendazole. Benzimidazoles function by inhibiting nuclear synthesis via binding tubulin and preventing microtubule assembly (Davidse, 1986).

Macrocyclic lactones are naturally occurring compounds, which are produced as a result of fermentation the soil dwelling bacterium Streptomyces avermitilis. Anthelminthic drugs within this class include avermectins and milbimycins; the most widely used drug in this class being ivermectin. Avermectins enhance the function of gluatamate, which is essential in invertebrate-specific glutamate-gated chloride channels (Cully, 1994). As a result of glutamate enhancement, electrical transmission in invertebrate nerve and muscle cells is blocked, causing paralysis.

Finally, imidazothiazoles are compounds consisting of an imidazole ring and a thiazole ring. The most common anthelminthic drug in this class is Levamisole. Levamisole rapidly paralyzes nematodes, which eventually leads to their death (Coles, et al., 1975). Later, it was discovered that Levamisole is a nicotinic acetylcholine receptor agonist, causing the continued stimulation of muscles in nematodes (Robertson et al., 1993). 
Due to overuse, $H$. contortus has developed resistance to each class of anthelminthic. A thorough study in 2013 evaluated $H$. contortus resistance to benzimidazole by genetic assessment of eggs, Fecal Egg Count Reduction Test (FECRT) and larval development assay. The study, conducted on Canadian sheep flocks, found H. contortus to be $100 \%$ resistant to fenbendazole and $92 \%$ resistant to thiabendazole (Barrere et al., 2013). However, resistance to thiabendazole has been documented since as early as 1964 (Conway, 1964). Thiabendazole was released in 1961 and a study reporting resistance to thiabendazole was released in 1964 (Drudge, et al., 1964). Albendazole was released in 1979 and resistance was reported the same year (Gunawan et al., 1979). Moxidectin (cydectin) is one of the most widely used deworming drugs.

Haemonchus contortus has developed multiple mechanisms of resistance against avermectin drugs. Isolates of $H$. contortus from South Africa and Australia. Avermectins were found to have decreased ability to inhibit larval development and reduce $L_{3}$ motility (Gill et al., 1993). Haemonchus contortus did not develop resistance to macrocyclic lactones as quickly as benzimadazoles, however resistance has been reported in each drug. Ivermectin was released in 1981 and resistance was reported in 1987 (Carmichael et al., 1987). Abamectin was the slowest to develop resistance in the macrocyclic lactone class, lasting 16 years before reported resistance (Wooster et al., 2001).

Imidazothiazoles are the smallest class of deworming drugs, but have held sensitivity for the longest amount of time. Levamisole was released in 1965 and the earliest report of resistance was in 1981 (Green et al., 1981). However, a 2008 report of anthelminthic resistance on farms in the Southeastern United States showed only 4 of 46 sheep farms had $H$. contortus resistant to levamisole (Howell et al., 2008). The same 
study showed 43 of 46 farms had $H$. contortus resistant to benzimidazole. However, a study performed over three years in Australia, a major producer of sheep, found levamisole resistance to $H$. contortus in $75 \%$ of the 51 operations tested (Playford et al., 2014).

\section{St. Croix Resistance to Haemonchus contortus}

Despite widespread, global resistance to de-worming drugs, St. Croix hair sheep have the natural ability to resist $H$. contortus infection. St. Croix hair sheep originate from the Caribbean island of St. Croix. St. Croix has a hot, humid climate 12 months each year. As such, $H$. contortus is prevalent year-round, resulting in constant challenge to native sheep, creating a requirement for enhanced response to infection.

St. Croix's resistance to $H$. contortus was first documented by dramatically lowered fecal egg count (Courtney et al., 1985). In this study, St. Croix lambs were found to have significantly lower fecal egg count (FEC) than tracer lambs and other native breeds (Courtney et al., 1985). Since Courtney's study, St. Croix's resistance to $H$. contortus has been well documented. In addition to lower fecal egg counts, terminal studies show St. Croix have significantly lower worm burdens in the abomasum compared to Dorset lambs (Gamble and Zajac, 1992). Further, when parasite naïve St. Croix sheep are experimentally infected with $H$. contortus for the first time, they have the ability to reduce their FEC to 0 by 5 week of infection, whereas parasite susceptible Suffolk sheep still had an observable FEC (Jacobs, 2013). When the same lambs were challenge infected with H. contortus, St. Croix lambs did not generate a FEC at any time point while Suffolk lambs had an FEC peaking at 8,000 eggs per gram feces (EPG) (Jacobs, 2013). A terminal study demonstrated that challenge infected St. Croix lambs had an average of 16 larvae 
per abomasum compared to 530 larvae in Suffolk lambs 10 days after infection (Sommers, 2014).

\section{Parasite Resistance is Immune Mediated}

The importance of immunity in combating $H$. contortus infection was confirmed in a study suppressing immunity using dexamethasone. In this study, Gulf Coast Native lambs, which possess moderate parasite resistance, were treated with dexamethasone and subsequently infected with $H$. contortus. Fecal egg count and larval counts were significantly higher in lambs treated with dexamethasone (Peña et al., 2003), indicating the importance of immune response during $H$ contortus infection. Comparison of immune parameters between parasite resistant and susceptible breeds of sheep has resulted differences in both innate and adaptive responses.

\section{Innate Response to Haemonchus contortus}

Eosinophilia is classically associated with helminth infections and Th2 responses (Baston et al., 1970). Immunity to parasites has been strongly correlated with increased eosinophilia in several models, including sheep. Eosinophils are granulated cells including substances such as histamine, eosinophil peroxidase, ribonuclease, deoxyribonuclease, lipase and plasminogen; all of which are released during degranulation in the presence of parasites to assist in expulsion (Reinhardt et al., 2011). Eosinophil degranulation around the parasite damages the worm cuticle, which can result in death (Moqbel, 1980).

In mice, eosinophilia has been shown to coincide with clearance and resistance to Trichuris muris (Else and Grencis, 1991), Nippostrongylus brasiliensis (Zhou et al., 1996) and Heligmosomoides polygyrus (Zhong and Dobson, 1996), but are not required for 
parasite expulsion (Herndon and Kayes, 1992). Similar to murine models, eosinophilia is associated with $H$. contortus infections in sheep and are capable of killing $H$. contortus larvae upon emergence from granulomas in as little as 24 hours (Meeusen and Balic, 2000). Eosinophils and their contents such as histamine, eosinophil peroxidase, ribonuclease, deoxyribonuclease, lipase and plasminogen have been shown to have helminthicidal properties (Reinhardt et al., 2011). Culturing of Trichinella spiralis larvae with eosinophil derived peroxidase leads to death within 20 minutes (Buys et al., 1980). However, studies depleting IL-5, responsible for eosinophil recruitment, during helminth infection has yielded differential results. Interleukin-5 mediated eosinophil depletion has no effect on parasite burden or memory response in $T$. spiralis (Herndon and Kayes, 1991) or Schistosoma mansoni infection (Sher et al., 1990), however, clearance times are increased.

In addition, eosinophils are capable of contributing to granulomas, which encapsulate parasites such as $H$. contortus. Eosinophilic granulomas have been found in abomasa of sheep, which are postulated to lead to damage and death to $H$. contortus larvae (Balic et al., 2006). Circulating and abomasal eosinophils are found to be greater during $H$. contortus infection in the parasite resistant breed Gulf Coast Native sheep compared to Sufolk (Shakya et al., 2011). Eosinophils were also found to be significantly increased in the abomasum of St. Croix sheep compared to a wool composite breed three days after $H$. contortus infection (MacKinnon et al., 2010), thus are associated with parasite resistance in sheep.

Neutrophils, known to be a first responder to infection, are increased in St. Croix abomasal tissue compared to Suffolk tissue as early as 3 days after $H$. contortus infection 
(Bowdridge et al., 2015). Neutrophils phagocytose pathogens such as viruses and bacteria and rid the body of cellular debris caused by pathogenic invasion. Though multicellular organisms such as helminths cannot be phagocytosed, neutrophils remain a first responder to the site of infection and are able to have helminth inhibiting effects. Neutrophils have been shown to produce neutrophil extracellular traps (NET) during helminth infections such as Strongyloides stercoralis (Bonne-Annee et al., 2014) and helminth eggs (Chuah et al., 2014). Trapping of larvae prohibits movement and may impede larval development. It is not yet known if neutrophils or NETs have helminthicidal properties. Interestingly, neutrophil recruitment has been found to be inhibited when IL4R $\alpha$ signaling is prevented (Chen et al., 2012). Mice lacking the ability to signal through IL-4Ra had decreased neutrophil accumulation and increased pathologies in association with N. brasiliensis infection (Chen et al., 2012).

Mast cells have been implicated in clearance of gastrointestinal helminth larvae, preventing the establishment of adults. Mast cells contain histamine and heparin and reside in many tissues. The generation of mast cells in the mucosa (mucosal mast cells) requires IL-3 production by activated T cells (Koketsu et al., 2013). Thymectomized mice do not experience mastocytosis during T. spiralis infection (Coffman et a., 1989). Mastocytosis was markedly increased in mice observed to be resistant to $H$. polygyrus infection (Behnke et al., 2003). Mast cells display the high-affinity lgE receptor on their cell surface (Arinobu et al., 2005). Cross linking of the IgE receptor causes release of mediators such as histamine, leukotriene C4 and eosinophil chemotactic factor (Franco et al., 2010). As IgE is associated with parasitic infections, including in $H$. contortus 
infection in sheep (MacKinnon et al., 2008), mast cells are likely to play an important role in the inflammatory process.

Alternatively activated macrophages are associated with helminth infections and may be required for optimal clearances and are activated by Th2 cytokines IL-4 and IL13. In a study in which Src-homology region 2 domain-containing phosphatase-1 (SHP1) was depleted in monocytes after T. muris infection, classically activated macrophages were over produced and worm expulsion was reduced (Hadidi et al., 2012). Macrophage and neutrophil co-culture with Strongyloides stercoralis resulted in significantly increased worm death than neutrophil culture with peripheral blood mononuclear cells (PBMC), which was also dependent on complement (Bonne-Annee et al., 2013). Further, neutrophils cultured with classically activated macrophages did not result in death of $S$. stercoralis while neutrophil culture with alternatively activated macrophages resulted in death of $90 \%$ of larvae (Bonne-Annee et al., 2013). Alternatively activated macrophages have been observed at the host-parasite interface during $H$. polygyrus infection in mice (Anthony et al., 2006). Alternatively activated macrophages were found to be recruited in mice after injection with excretory / secretory product derived from the parasite Fasciola hepatica (Donnelly et a., 2005). Confirmation of alternatively activated macrophages in sheep during $H$. contortus infection has not yet been published, though their presence is likely based on the Th2 profile seen in sheep during haemonchosis. Differentiation from classically to alternatively activated macrophages requires IL-4 as IL-4-deficient mice are unable to produce alternatively activated macrophages while neutrophil infiltration was unchanged (Anthony et al., 2006). More work is required to elucidate their role in sheep during $H$. contortus infection. 
Innate cells typically recognize pathogens via pathogen associated molecular patterns (PAMPs) located on the surface of the pathogen. Molecular patterns that induce immune response have not been identified in the context of $H$. contortus infection. Evidence suggests $H$. contortus surface cuticular proteins are differential, depending on life stage, which may contribute to the worm's ability to evade immune targeting, but largely contain collagens (Cox et al., 1989). A study was conducted that used antibody secreting cell probes and cell culture supernatant probes to isolate protein antigens in a repeatable, $H$. contortus stage specific study (Bowles et al., 1995), however little has been accomplished to identity these proteins in the last 20 years.

Innate cells recognize PAMPs by pattern recognition receptors (PRR) on the surface of the immune cell. Several PRR have been implicated in various parasitic infections. Excretory/secretory product released by Acanthocheiloneum viteae has been found to stimulate dendritic cells (DC) to produce Th2 cytokines through the PRR toll-like receptor (TLR) 4 (Whelan et al., 2000). Additionally, schistosomes stimulate DC to produce IL-10 in a Th2-dependent manner which requires TLR2 (van der Kleij et al., 2002). Lectins have been shown to be associated with nematodes such as Toxocara canis (Page et al., 1992) and H. contortus eggs (Palmer and McCombe, 1996). Lectins are capable of being recognized by C-type lectin receptors (CLR) such as Dectin-1 and mannose receptor (MR / CD206), which are associated with alternatively activated macrophages (Fairweather and Cihakova, 2009).

Haemonchus contortus infection is associated with tissue damage as the parasite utilizes a stylet to puncture the tissue in order to take a blood meal (Albers and Le Jambre, 
1983) which may produce danger associated molecular patterns (DAMPs). Cytosolic components and ATP are each DAMPs, which may signal innate cells through PRRs.

Inflammasomes are large, protein oligomers with similar basic components. Mammals have genes for 23 NOD-like receptor (NLR) families (PRRs), which are the basis for forming inflammasomes (Guo et al., 2015). NLR proteins themselves consist of two domains: leucine rich repeats (LRR) and the nucleotide binding domain (NBD/NACHT) (Guo et al., 2015). The NBD region is important for oligomerization with other NLR proteins. Some NLRs contain a pyrin domain (PYD) at the N-terminus. The LRR, located at the C-terminus, is used as ligand recognition for other PRRs. NLR must recruit other proteins to form the inflammasome. Apoptosis-associated speck-like protein (ASC) consists of its own PYD domain, which interacts with the PYD domain of NLR as well as a Cardinal (CARD) domain. The CARD domain of ASC interacts with the CARD domain of pro-caspase- 1 , which allows cleavage of the CARD domain, creating active caspase- 1 , which in turn is able to cleave pro-IL-1 $\beta$ into active IL-1 $\beta$ or pro-IL-18 into its active form, which are both highly inflammatory cytokines. If PYD is absent, such as in NLRC4, a CARD domain is present at the N-terminus. CARD specifically recruits procaspase-1, eliminating the need to recruit ASC. NLRP proteins contain PYD domains and may or may not have CARD domains (Guo et al., 2015).

The role of the inflammasome is poorly studied in most helminth infections, but has been studied in some protozoan parasites. Inflammasome activation is known to occur in response to infection by protozoan parasites including Trypanosoma species and Leishmania species. NLRP3 is protective in Trypanosoma cruzi infection, which is the causative agent of Chaga's disease (Goncalves et a., 2013). Models using ASC and 
caspase-1 knockouts in whole mice or macrophages revealed increased parasite burdens during $T$. cruzi infection, revealing a critical protection conferred by the inflammasome (Silva et al, 2016). Macrophage NLRP3 knockout mice infected with T. cruzi showed an inability of macrophages to kill $T$. cruzi, however blocking IL-1 $1 \beta$ or IL-18 did not have the same effect, in that mice were still protected. The ability of macrophages to kill parasites was attributed to NO2 production as a result of inflammasome activation.

Activation of NLRP3 has been found in response to Leishmania amazonensis, however, there is debate as to its role. One study found limited $L$. amazonensis growth within macrophages associated with NLRP3 activation, while simultaneously reporting little caspase-1 cleavage of IL-1 (Gurung et al., 2015). Therefore, the mechanism of protection conferred by NLRP3 activation in L. amozonesis infection is unknown.

In the case of multicellular parasites, the role of the inflammasome is less known. Recent studies have shown the ability of NLRP3 to act as a transcription factor in T cells (Bruchard et a., 2015). NLRP3 translocates to the nucleus via importin and is able to transactivate transcription of IL-4 and other Th2 associated cytokines. The inflammasome is not formed in these T cells and associated proteins such as ASC and CARD are not required for resulting Th2 activation. Th17 activation also appears to be somewhat dependent on NLRP3 acting as a transcription factor (Bruchard et al., 2015). In these studies, absence of NLRP3 resulted in decreased ability for Th2 and Th17 activation. Inflammasome formation is unknown during $H$. contortus infection or if NLRP3 enhances early Th2 responses during haemonchosis. 


\section{Adaptive immune response to Haemonchus contortus}

Early innate responses to $H$. contortus direct T cell responses which occur soon after. Dexamethasone depletion in $H$. contortus immunized sheep causes significantly increased parasite burden in a timed fashion (Adams, 1982). If leukocytes are depleted intermittently during early infection, parasite load is significantly impacted. However, if depletion is constant and chronic, there is no impact on parasite burden (Adams, 1982). T cells, in particular are crucial to the ability to expel helminth parasites. CD4+ T cells were depleted in a timed fashion in mice during $H$. polygyrus infection using anti-CD4 antibody. In agreement with dexamethasome-mediated cell depletion in sheep, parasite burdens were significantly increased if CD4+ T cells were depleted during early $H$. polygyrus infection (Anthony et al., 2006). Depletion of CD4+ T cells during mid infection resulted in a marginal increase in parasite burden and depletion during late infection had no effect on parasite burden (Anthony et al., 2006), implicating the importance of early recognition and response to helminth infection.

The importance of CD4+ T cells has also been demonstrated in sheep during $H$. contortus infection. Infection by $H$. contortus results in increased $\mathrm{CD} 4^{+} \mathrm{T}$ cells and increased abomasal lymph nodes (ALN) by 3 days after experimental infection, which continued to increase to day 5 (Balic et al., 2000). Lymph node weight was also increased two-fold, which indicates an increase of cells presenting antigen in the lymph nodes as a result of $H$. contortus infection (Balic et al., 2000). Gulf Coast Native sheep were depleted of CD4+ T cells by anti-ovine CD4 monoclonal antibody, administered for three weeks. Fecal egg counts in CD4+ T cell depleted sheep were significantly higher days 21 and 28 after $H$. contortus infection indicating increased abomasal worm burden (Peña et al., 
2006). Adult worms were enumerated in the abomasum revealing animals treated with anti-CD4 antibody had greater worm load than controls (1743 \pm 356 vs. $698 \pm 308$, respectively) (Peña et al., 2006).

Parasite infections typically illicit a T helper type 2 (Th2) immune response by CD4+ T cells, which is vital to parasite clearance. $T$ helper type 2 responses are characterized by secretion of the cytokines IL-4, IL-13, IL-5 and IL-10. Differentiation to Th2 subset requires the transcription factor GATA-3. Up-regulation of GATA-3 is stimulated by IL-4 signaling, however full Th2 differentiation requires T cell receptor (TCR) signaling to increase the translation rate of GATA-3 (Cook and Miller, 2010). Increased GATA-3 translation through TCR stimulation utilizes the PI3K / rapamycin pathway and is therefore independent of cell activation or proliferation, but required for Th2 differentiation (Cook and Miller, 2010).

Many sources of early IL-4, critical for Th2 differentiation, have been implicated. Neutrophils are a first responder during parasitic infections, including $H$. contortus infection (Bowdridge et al., 2015). Depletion of neutrophils during Leishmania major infection in BALB/c mice inhibited the development of Th2 immunity, indicating the possibility for neutrophil driven IL-4 (Tacchini-Cottier et al., 2000). Human neutrophils have already been proven to generate IL-4 (Brandt et al., 2000), however IL-4 production by neutrophils during helminth infection, has not been patently proven.

Eosinophils, basophils and mast cells are commonly cited as sources of IL-4 during parasite infection (Coffman and Weid, 1997), however these cells must be stimulated to release IL-4. Stimulation may be accomplished through epithelial release of IL-25 (IL17E) (Fallon et al., 2006), which may also prime a population of innate lymphoid cells 
(ILC) to produce Th2 cytokines (Fallon et al., 2006). During N. brasiliensis infection, il251- mice were unable to clear the infection and had a significant decrease of type 2 cytokines IL-4, IL-5 and IL-13 (Fallon et al., 2006).

Parasite resistant St. Croix sheep have increased IL-4 mRNA in the abomasum 3 days after experimental $H$. contortus infection compared to Suffolk crossbred sheep and control St. Croix sheep (Jacobs et al., 2016 [Appendix II]). IL-4 mRNA is increased in these animals on days 5 and 7 after infection as well, while there is no detectable IL-4 mRNA in Suffolk abomasum at any of these time points (Jacobs et al., 2016). Significantly decreased larvae were found in the abomasum of St. Croix lambs at these time points (Jacobs et al., 2016), suggesting St. Croix sheep may induce Th2 profiles sooner during H. contortus infection, allowing more efficient and timely expulsion of larave. In addition to increased IL-4 mRNA at the site of infection, St. Croix sheep have increased circulating IL-4 during early $H$. contortus infection in association with lower fecal egg count (FEC) (Jacobs et al., 2015).

Naïve T cells may be stimulated to release IL-4 in the presence of IL-6, which would drive the Th2 differentiation of local T cells by autocrine and paracrine action (Rincon et al., 1997). Antigen presenting cells (APC) release IL-6, stimulating IL-4 production from naïve T cells (Rincon et al., 1997) or NKT cells (Yoshimoto and Paul, 1994) which both stimulates Th2 differentiation and antagonizes IL-12 mediated Th1 differentiation.

Each of these cells are possible sources of IL-4 during early parasite infection necessary for Th2 differentiation. It is likely each of these cells contribute in concert to Th2 differentiation crucial to parasite expulsion, however the exact order of events is not currently known. In order for Th2 differentiation to occur in the presence of IL-4, it must 
bind and ligate its receptor IL-4Ra. When IL-4 binds to IL-4Ra, Janus kinases (Jak) 1 and 3 are phosphorylated, which in turn phosphorylate signal transducer and activator of transcription 6 (STAT6) (Nelms et al., 1999). STAT6 dimerizes and translocates to the nucleus where it is able to up-regulate Th2 genes (Nelms et al., 1999). Interestingly, while naïve T cells over express IL-4Ra, ligation of the TCR in either IL-4 or IL-12 primed cells inhibits transduction of signal by IL-4Ra (Zhu et al., 2000). Subunits of thelL-13 receptor may also associate with IL-4R $\alpha$, in which case ligation by IL-13 causes phosphorylation of STAT3, which translocates to the nucleus (Wills-Karp and Finkelman, 2008), furthering the Th2 profile via GATA-3. IL-4R $\alpha$ is crucial to clearance of S. mansoni infection as I/4ra-/- mice were unable to clear infection (Dewals et al., 2009).

$B$ cells

In addition to activating Th2 profiles, CD4+ $\mathrm{T}$ lymphocytes activate B cells, which create specific antibodies to antigen. In the absence of $\mathrm{CD} 4^{+} \mathrm{T}$ cells, adaptive immunity is unable to develop, resulting in an amnestic response upon challenge. The role of $B$ cells in parasite expulsion is related to the life cycle of the parasite. B cells are most highly implicated in their ability to secrete antibody, however some findings suggest B cells enhance Th2 responses. One such study suggests that B cells provide the stimulus for $T$ cells to bring producing IL-4 in the B zone of local draining lymph nodes through their expression of OX40L (Linton et al., 2003). Additionally, when B cells are absent, T cell profiles can be observed shifting from Th2 to Th1 differentiation (Bradley et al., 2002), even during helminth exposure using S. mansoni eggs (Hernandez et al., 1997).

Studies show B cell presence is critical in expulsion of nematode parasites with strictly enteric life cycles such as $H$. polygyrus and $H$. contortus while parasites utilizing 
hepato-tracheal migration prior to enteric establishment, such as $N$. brasiliensis, are not B cell-dependent. B cell requirement for protection to enteric parasite infection indicatesa role for Peyer's patches, which are located in the gut (Liu et al., 2010). Peyer's patches are a form of organized Gut Associated Lymphoid Tissues (GALT), which contain specialized microfold cells ( $M$ cells) capable of sampling and presenting antigen to T cells in follicles within the Peyer's patch. Follicular $T$ helper $\left(T_{F H}\right)$ cells surround a large amount of B cells found in germinal centers of Peyer's patches and present antigen to them (Murphy, 2012). Mice deficient of B cells were unable to clear a challenge infection of $H$. polygyrus(Liu et al., 2010). Typically, H. polygrus primary inoculation results in a chronic infection, however if treated with anthelminthics and given a challenge dose of $H$. polygyrus, mice are able to expel the parasite within 2 weeks of challenge. Mice deficient in B cells were not able to expel adult worms in a challenge infection, however FEC was similar between B-cell deficient and primary infected wild-type mice, indicating there is no effect on parasite fecundity (Liu et al., 2010). The presence and accumulation of B cells both locally and in the draining lymph node during helminth infection indicate a role for these cells and consequently the antibody that B cells generate.

\section{Humoral responses to $\mathrm{H}$. contortus}

The primary function of $B$ cells in any immune response is production of antibody. During helminth infection, the presence of Th2 cytokines promotes antibody class switching in $B$ cells to immunoglobulin $E$ ( $\lg E$ ) and IgG2 (human) or lgG1 (mouse) through T and B cell interactions and IL-4Ra signaling. As previously mentioned, cross linkage of $\lg \mathrm{E}$ via FceR1 on the surface of mast cells promotes their degranulation. Despite this function, IgE does not contribute to the development of protective immunity in several 
helminth models including H. polygyrus (McCoy et al., 2008), N. brasiliensis (Watanabe et al., 1988) and S. mansoni (Ridi et al., 1998), though they do contribute to their clearance.

During $H$. contortus infection, $\lg G, \lg E$ and $\lg A$ are increased in parasite resistant sheep (Schallig, 2000). Antibodies can be produced during primary and challenge infections, with lgA typically produced in response to larvae and specific $\lg G 1$ and $\lg G 2$ in response to adults (Schallig et al., 1994). IgA responses during primary infection develop slowly, but develop more rapidly during challenge infection, indicating an anamnestic response being made to $H$. contortus in Texel sheep, which are thought to be somewhat resistant to $H$. contortus infection. Furthermore, it was determined that serum IgA production against $L_{3}$ larvae and serum $\lg G 1$ and $\lg G 2$ production against adult worms increased slowly during primary infections and quickly during early challenge infection. During the course of $H$. contortus infection, serum antibody titers were doubled during challenge infection compared to primary infection (Schallig et al., 1994). Antibody may also work in cooperation with complement to trap $H$. contortus larvae, inhibiting their movement and growth and leaving them susceptible to damage by immune cells (Garza et al., 2016)

Antibody production has been documented to play a crucial role in defense against $H$. contortus. $\lg A, \lg E$ and antigen specific $\lg G$ have been shown to be elevated in $H$. contortus infections (Kooyman et al., 1997; Lacroux et al., 2006; Meeusen et al., 2005). In fact, circulating levels of antigen specific IgG were found to decrease in parasite susceptible Suffolk sheep during $H$. contortus infection (Jacobs, 2013). Resistant breeds of sheep have been shown to generate greater antibody responses upon primary and 
challenge infection with $H$. contortus, as well as having more circulating IgA in noninfected animals (MacKinnon et al., 2010). No differences in circulating lgE levels were observed between parasite susceptible and parasite resistant breeds, however higher concentrations of $\lg E$ in lymph node extract was observed 27 days after infection (MacKinnon et al., 2010). Infected, resistant sheep had higher levels of IgA as early as 3 days and as late as 21 days after infection when compared to parasite susceptible sheep. These data indicate a role for antibodies in parasite clearance and the development of full protective immunity in parasite resistant sheep (MacKinnon et al., 2010).

In order for antibodies to be made, B cells must be present and activated by $\mathrm{T}$ cells. As previously mentioned, mice deficient in B cells were infected with $H$. polygyrus. As expected, B cell deficient mice were not able to produce antibody in response to a primary or secondary infection leading to inability to clear a challenge infection, as described above (Liu et al., 2010). These data indicate a role for antibody produced by B cells as an effector molecule contributing to parasite expulsion.

There is a clear role for humoral immunity in parasite resistant breeds of sheep. To illustrate this dexamethasone was used to suppress immunity. Lymphocyte count in dexamethasone treated sheep were significantly lower than control sheep and furthermore, antibodies to whole worm antigen were decreased in both dexamethasone treated age groups compared to controls (Peña et al., 2004). Reduction in lymphocyte and antibody responses resulted in higher worm burden of dexamethasone treated groups (Peña et al., 2004).

The mechanisms underlying early development to immune responses to parasite infections in general are poorly understood. As demonstrated, the exact timelines of 
innate cells response, mechanisms of parasite recognition, initiation of signaling pathways are still under investigation. It is clear the timing of these events greatly contribute to the ability of St. Croix sheep to expel and protect against $H$. contortus infection, though the critical requirements remain evasive. Therefore, a need exists to clarify responses of immune cells to $H$. contortus in both parasite susceptible and resistant breeds of sheep. As such, the goals of these experiments are to characterize the upregulation of immune associated genes in response to $H$. contortus antigens in peripheral blood mononuclear cells (PBMC) of primed, resistant St. Croix sheep and susceptible Suffolk sheep.

PBMC contain monocytes and lymphocytes including $T$ cells and $B$ cells. Monocytes are capable of presenting antigen to $\mathrm{T}$ cells and, in primed animals, a population of T cells within PBMC should be memory T cells, with TCR specific for $H$. contortus antigen. Using these cell populations in culture with $H$. contortus antigens and analyzing gene expression and IL-4 production may shed light on how immune responses are developed and controlled in parasite resistant and susceptible sheep when exposed to $H$. contortus. 


\section{Literature Cited}

Adams, D. 1982. Time of onset and target of immune reactions in sheep with acquired immunity against Haemonchus contortus. Int. J. Parasit. 12: 439-443.

Albers, G., and L. Le Jambre. 1983. Erythrocyte potassium concentration: a simple parameter for erythropoiesis in sheep infected with Haemonchus contortus. Res. Vet. Sci. 35: 273-276

Anthony, R., Urban, J., Alem, F., Hamed, H., Rozo, C., Boucher, JL., Van Rooijen, N., and W Gause. 2006. Memory $\mathrm{T}(\mathrm{H}) 2$ cells induce alternatively activated macrophages to mediate protection against nematode parasites. Nat. Med. 12: 955-960.

Arinobu, Y., Iwasaki H., Gurish, MF., Mizuno, S., Shigematsu, H., Ozawa, H., Tenen DG., Austen, KF., and K. Akashi. 2005. Developmental checkpoints of the basophils/mast cell lineages in adult murine hematopoiesis. PNAS. 102(50): 18105-18110.

Balic, A., V. Bowles, and E. Meeusen. 2000. Cellular profiles in the abomasal mucosa and lymph node during primary infection with Haemonchus contortus in sheep. Vet. Immunol. Immunopath. 75: 109-120.

Barker, HA., Smyth, RD., Weissbach, H., Toohey, JI., Ladd, NJ., and BE Volcani. 1960. Isolation and Properties of Crystalline Cobamide Coenzymes Containing Benzimidazole or 5,6-Dimethylbenzimidazole. J Biol Chem. 235(2): 480-488.

Barrere, V., Falzon, LC., Shakya, KP., Menzies, PI., Peregrine, AS., and RK Prichard. 2013. Assessment of benzimidazole resistance in Haemonchus contortus in sheep flocks in Ontario, Canada: comparison of detection methods for drug resistance. Vet Parasitol. 198(1-2): 159-65.

Behnke, JM., Lowe, A., Clifford S., and D Wakelin. 2003. Cellular and serological responses in resistant and susceptible mice exposed to repeated infection with Heligmosomoides polygyrus bakeri. Parasit. Immunol. 25(6): 333-340.

Bonne-Annee, S., Kerepesi, LA., Hess, JA., O'Connell, AE., Lok, JB., Nolan, TJ., and D Abraham. 2013. Human and mouse macrophages collaborate with neutrophils to kill larval Strongyloides stercoralis. Infec and Immunity. 81(9): 3346-3355.

Bonne-Annee, S., Kerepesi, LA., Wesolowski, J., Paumet, F., Lok, JB., Noal, TJ and D Abraham. 2014. Extracellular traps are associated with human and mouse neutrophil and macrophage mediated killing of larval Strongyloides stercoralis. Microbes Infec. 16(6): 502-11. 
Bowdridge, S., Mackinnon K., McCann J., Zajac, A., and D. Notter. 2013. Hair-type sheep generate an accelerated and longer-lived humoral immune response to Haemonchus contortus infection. Vet. Parasitol. 196: 172-178.

Bowdridge, SA., Zajac, AM., and DR Notter. 2015. St. Croix sheep produce a rapid and greater cellular immune response contributing to reduced establishment of Haemonchus contortus. Vet Parasitol. 208(3-4): 204-10.

Bowles, VM., Brandon, MR., and ENT Meeusen. 1995. Characterization of local antibody responses to the gastrointestinal parasite Haemonchus contortus. Immunology. 84(4): 669-674.

Bradley, LM., Herbertson, J., Biderman, E., Zhang, Y., Bradley SM., and PJ Linton. 2002. Availability of antigen-presenting cells can determine the extent of CCD4 effector expansion and priming for secretion of Th2 cytokines in vivo. Eur $\mathrm{J}$ Immunol. 32(8): 2338-2346.

Brandt E., Woerly, G., Younes, AB., Loiseau S., and Capron M. 1999. IL-4 production by human polymorphonuclear neutrophils. J Leukoc Biol. 68(1): 125-130.

Buys, J., Wever, R., van Stigt, R., and EJ Ruitenberg. 1981. The killing of newborn larvae of Trichinella spiralis by eosinophil peroxidase in vivo. Eur $\mathrm{J}$ Immunol. 11(10): 843-5.

Carmichael, I., Visser, R., Schneider, D., and M. Soll. 1987. Haemonchus contortus resistance to ivermectin. J S Afr Vet Assoc. 58(2): 93.

Chen, F., Z. Liu, W. Wu, C. Rozo, S. Bowdridge, A. Millman, N. Van Rooijen, J. Urban, T. Wynn, and W. Gause. 2012. An essential role for TH2-type responses in limiting acute tissue damage during experimental helminth infection. Nat. Med. 18: 260-266.

Chuah, C., Jones, MK., Burke, ML., McManus, DP., Owen, HC., and GN Gobert. 2014. Defining a pro-inflammatory neutrophil phenotype in response to schistosome eggs. Cell Microbiol. 16(11): 1666-77.

Coffman RL and T Weid. 1997. Multiple pathways for the initiation of Thelper 2 (Th2) responses. JEM. 185(3): 373-376.

Coffman, R., B. Seymour, S. Hudak, J. Jackson, and D. Rennick. 1989. Antibody to interleukin-5 inhibits helminth-induced eosinophilia in mice. Science 245: 308310.

Coles, GC., East, JM., and SN Jenkins. The mechanism of action of the anthelmintic levamisole. 1975. Gen Pharm Vas. 6(4): 309-313. 
Cook, KD and J Miller. 2010. T cell receptor-dependent translational control of GATA-3 enhances Th2 differentiation. J Immunol. 185(6): 3209-3216.

Conway, DP. 1964. Variance in the effectiveness of thiabendazole against Haemonchus contortus in sheep. Am J Vet Res. 25:844-6.

Courtney, C., C. Parker, K. McClure, and R. Herd. 1985. Resistance of nonlambing exotic and domestic ewes to naturally acquired gastrointestinal nematodes. Int. J. Parasit. 15: 239-243.

Cox, GN., Shamansky, LM., and RJ Boisvenue. 1989. Identification and preliminary characterization of cuticular surface proteins of Haemonchus contortus. Mol Biochem Parasitol. 36(3): 233-41.

Crofton, H. 1954. Nematode parasite populations in sheep on lowland farms. 1. Worm egg counts in ewes. Parasit. 44: 465-477.

Cully, DF., Vassilatis, DK., Liu, KK., Paress, PS., Van der Ploeg, LH., Schaerffer, JM., and JP Arena. 1994. Cloning of an avermectin-sensitive glutamate-gated chloride channel from Caenorhabditis elegans. Nature. 371(6499): 707-711.

Daniel, JA., and JE Held. 2006. Testing intervention strategies to reduce the prevalence of lung lesions in lambs. South Dakota Sheep Research Reports. 2006-2007.

Davidse LC. 1986. Benzimidazole fungicides: mechanism of action and biological impact. Ann Rev Phytopath. 24: 43-65.

Dewals, B., J. Hoving, M. Leeto, R. Marillier, U. Govender, A. Cutler, W. Horsnell, and F. Brombacher. 2009. IL-4Ralpha responsiveness of non-CD4 T cells contributes to resistance in Schistosoma mansoni infection in pan-T cell-specific IL-4Ralphadeficient mice. Am. J. Pathol. 175: 706-716.

Drudge, JH., Szanto, J., Wyant, ZN., and G Elam. 1964. Field studies on parasite control in sheep: comparison of thiabensazole, ruelene, and phenothiazine. Am J Vet Res. 25: 1512-1518.

Else, KJ., and Grencis, RK. 1991. Cellular immune responses to the murine nematode parasite Trichuris muris. Differential cytokine production during acute or chronic infection. Immunology. 72(4): 508-513.

Fairweather D and D Cihakova. 2010. Alternatively activated macrophages in infection and autoimmunity. J Autoimmun. 33(3-4): 222-230.

Fallon, PG., Ballantyne, SJ., Mangan NE., Barlow JL., Dasvarma, A., Hewett, DR., Mcllgorm, A., Jolin, HE., and McKenzie ANJ. 2006. Identification of an interleukin (IL)-25-dependent cell population that provides IL-4, IL-5, and IL-13 at the onset of helminth expulsion. JEM. 203(4): 1105-1116. 
Food and Agriculture Organization of the United Nations. 2015. Meat and meat products report.

Franco, CB., Chen, CC., Drukker, M., Wissman IL., and SJ Galli. 2010. Distinguishing mast cell and granulocyte differentiation at the singe cell level. Cell Stem Cell. 6(4): 361-368.

Gamble HR and AM Zajac. 1992. Resistance of St. Croix lambs to Haemonchus contortus in experimentally and naturally acquired infections. Vet Parasitol. 41(34): $211-225$.

Garza, J.J., S.P. Greiner, S.A. Bowdridge, 2016. Serum-mediated H. contortus larval aggregation differs by larval stage and is enhanced by complement. Parasit. Immunol. In revision.

Georgi, J., and J. Whitlock. 1967. Erythrocyte loss and restitution in ovine haemonchosis. Estimation of erythrocyte loss in lambs following natural exposure. Cornell Vet. 57: 43-53.

Gill, JH., Kerr CA., Shoop WL., and E Lacey. 1998. Evidence of multiple mechanisms of avermectin resistance in Haemonchus contortus-comparison of selection protocols. Int J Parasitol. 28(5): 783-9.

Goncalves, VM., Matteucci, KC., Buzzo CL., Miollo, BH., Ferrante, D., Torrechihas, AC., Rodrigues, MM., Alvarez, JM., and KR Bortoluci. 2013. NLRP3 controls Trpanosoma cruzi infection through Caspase-1-dependent IL-1R-Independent NO production. PLoS Negl Trop Dis. 7(10): e2479.

Green, PE., Forsyth, BA., Rowan, KJ., and G Payne. 1981. The isolation of a field strain of Haemonchus contortus in Queensland showing multiple anthelmintic resistance. Aust Vet J. 57(2): 79-84.

Gou, H., Callawa, JB., and JPY Ting. 2015. Inflammasomes: mechanisms of action, role in disease and therapeutics. Nat Med. 21(7): 677-687.

Gunawan, M., Sangster, NC., Kelly, JD., Griffin, D., and HV Whitlock. 1979. The efficacy of fendendazole and albendazole against immature and adult stages and benzimidazole-resistant sheep trichostrongylids. Res Vet Sci. 27(1): 111-115.

Gurung, P., Karki, R., Vogel, P., Watanabe, M., Bix, M., Lamkanfi, M., and Kanneganti, TD. 2015. An NLRP3 inflammasome-triggered Th2 biased adaptive immune response promotes leishmaniasis. J Clin Invest. 125(3): 1329-1338.

Hadidi S., Antignano F., Hughes MR., Wang, SK., Snyder, K., Sammis GM., Kerr WG., McNagny, KM and C Zaph. 2012. Myeloid cell-specific expression of Ship1 
regulates IL-12 production and immunity to helminth infection. Mucosal Immunol. 5(5): 535-543.

Herd, R., R. Streitel, K. McClure, and C. Parker. 1983. Control of periparturient rise in worm egg counts of lambing ewes. J. Am. Vet. Med. Assoc. 182: 375-379.

Herndon, FJ., and SG Kayes. 1992. Depletion of eosinophils by anti-IL-5 monoclonal antibody treatment of mice infected with Trichinella spiralis does not alter parasite burden of immunologic resistance to reinfection. J Immunol. 149(11): 3642-3647.

Howell, S., J. Burke, J. Miller, T. Terrill, E. Valencia, M. Williams, L. Williamson, A. Zajac, and R. Kaplan. 2008. Prevalence of anthelmintic resistance on sheep and goat farms in the southeastern United States. J. Am. Vet. Med. Assoc. 233: 1913-1919.

Jacobs, JR. 2013. Characterizing peripheral cellular and humoral immune responses to Haemonchus contortus in sheep. Retrieved from ProQuest. 1549753.

Jacobs, JR., Greiner, SP., and SA Bowdridge. 2015. Serum interleukin-4 (IL-4) production is associated with lower fecal egg count in parasite-resistant sheep. Vet Parasitol. 211(1-2): 102-5.

Jacobs, JR., Sommers, KN., Zajac, AM., Notter, DR., and SA Bowdridge. 2016. Early IL-4 gene expression in abomasum is associated with resistance to Haemonchus contortus in hair and wool sheep breeds. Parasit Immunol. 38(6): 333-339.

Kemp, J., Robinson, N., Meeusen, E., and D. Piedrafita. 2009. The relationship between the rapid rejection of Haemonchus contortus larvae with cells and mediators in abomasal tissues in immune sheep. Int. J. Parasit. 39: 1589-1594.

Koketsu, R., Yamaguchi, M., Suzukawa, M., Tanaka, Y., Tashimo, H., Arai, H., Nagase, H., Matsumoto, K., Saito, H., Ra, C., Yamamoto, K., and K. Ohta. 2013. Pretreatment with Low Levels of FcERI-Crosslinking Stimulation Enhances Basophil Mediator Release. Int. Arch. Aller. Imm. 161 Suppl 2: 23-31.

Kooyman, F., Van Kooten, P., Huntley, J., MacKellar, A., Cornelissen, A. and H. Shallig. 1997. Production of a monoclonal antibody specific for ovine immunoglobulin $E$ and its application to monitor serum IgE responses to Haemonchus contortus infection. Parasitol. 114(4): 395-406.

van der Kleij, D., Latz, E., Brouwers, JF., Kruize, YC., Schmitz, M., Kurt-Jones EA., Espevik T., de Jong, EC., Kaspenberg, ML., Golenbock, DR., Tielens, AG., and $M$ Yazdanbakhsh. 2002. A novel host-parasite lipid cross-talk. Schistosomal lysophosphatidylserine activates toll-like receptor 2 and affects immune polarization. J Biol Chem. 277:48122-48129. 
Lacroux, C., Nguyen, TH., Adreoletti, FP., Grisez, C., Bergeaud, JP., Gruner, F., Brunel, JC., Francois, D., Dorchies, P., and Jacquiet, P. 2006. Haemonchus contortus (Nematoda: Trichostrongylidae) infection in lambs elicits an unequivocal Th2 immune response. Vet Res. 37: 607-622.

Linton, PJ., Bautista, B., Biderman, E., Bradley, ES., Herbertson, J., Kondrack, RM., Padrick, RC., and LM Bradley. 2003. Costimulation via OX40L expressed by B cells is sufficient to determine the extent of primary CD4 expansion and Th2 cytokine secretion in vivo. J Exp Med. 197(7): 875-883.

Liu, Q., Kreider, T., Bowdridge, S., Liu, Z., Song, Y., Gaydo, A., Urban, J., and W. Gause. 2010. B cells have distinct roles in host protection against different nematode parasites. Am J Vet Res. 36:1459-1464.

MacKinnon, KM., Burton, JL., Zajac, AM., and DR Notter. 2009. Microarray analysis reveals difference in gene expression profiles of hair and wool sheep infected with Haemonchus contortus. Vet Immunol and Immunopathol. 130(3-4): 210-22.

MacKinnon, K., A. Zajac, F. Kooyman, and D. Notter. 2010. Differences in immune parameters are associated with resistance to Haemonchus contortus in Caribbean hair sheep. Parasit. Immunol. 32: 484-493.

McCoy, KD., Stoel, M., Stettler, R., Merky, P., Fink, K., Senn, BM., Schaer, C., Massacand, J., Odermatt, B., Oettgen, HC., Zinkernagel, RM., Bos, NA., Hengartner, H., Macpherson, AJ., and NL Harris. 2008. Polycolonal and specific antibodies mediate protective immunity against enteric helminth infection. Cell Host Microbe. 4(4): 362-373.

Meeusen ENT and A. Balic. 2000. Do eosinophils have a role in the killing of helminth parasites? Parasitol Today. 16(3): 95-101.

Min, B., Prout M., Hu-Li, J., Zhu, J., Jankovic, D., Morgan ES., Urban, JF Jr., Dvorak, AM., Finkelman, FD., LeGros G., and WE Paul. 2004. Basophils produce IL-4 and accumulate in tissues after infection with a Th2-inducing parasite. J Exp Med. 200(4): 507-517.

Moqbel, R. 1980. Histophatological changes following primary, secondary and repeated infections of rats with Strongyloides ratti, which special reference to tissue eosinophils. Parasit Immunol. 2(1): 11-27.

Nelms, K., Keegan, AD., Zamorano, J., Ryan JJ., and WE Paul. 1999. The IL-4 receptor: signaling mehcanisms and biologic functions. Ann Rev Immunol. 17: 701-738. 
Ockerman, HW., Emsen, H., Parker, CF., and CJ Pierson. 1982. Influence of type (wooled or hair) and breed on growth and carcass characteristics and sensory properties of lamb. J Food Sci. 47(4): 1365-1368.

Page, AP., Rudin, W., Fluri, E., Blaxter, ML., and RM Maizels. 1992. Toxocara canis: a labile antigenic surface coat overlying the epicuticle of infective larvae. Exp Parasitol. 75(1): 72-86.

Palmer, DG and IL McCombe. 1996. Lectin staining of trichostrongylid nematode eggs of sheep: rapid identification of Haemonchus contortus eggs with peanut agglutinin. Int J Parasitol. 26(4): 447-450.

Peña, M., Miller, J., and D. Horohov. 2004. Effect of dexamethasone treatment on the immune response of Gulf Coast Native lambs to Haemonchus contortus infection. Vet. Parasitol. 119: 223-235.

Peña, M., J. Miller, and D. Horohov. 2006. Effect of CD4+ T lymphocyte depletion on resistance of Gulf Coast Native lambs to Haemonchus contortus infection. Vet. Parasitol. 138: 240-246.

Playford, MC., Smith, AN., Love, S., Besier, RB., Kluver, P., and JN Bailey. 2014. Prevalence and severity of anthelmintic resistance in ovine gastrointestinal nematodes in Australia (2009-2012). Aust Vet J. 92(12): 464-471.

Reinhardt, S., Scott I., and H. Simpson. 2011. Neutrophil and eosinophil chemotactic factors in the excretory/secretory products of sheep abomasal nematode parasites: NCF and ECF in abomasal nematodes. Parasit. Res.109: 627-635.

Robertson, SJ and RJ Martin. 1993. Levamisole-activated single- channel currents from muscle of the nematode parasite Ascaris suum. Br J Pharmacol. 108: 170-178.

Roeber, F., A. Jex, and R. Gasser. 2013. Impact of gastrointestinal parasitic nematodes of sheep, and the role of advanced molecular tools for exploring epidemiology and drug resistance - an Australian perspective. Parasit. Vectors 6: 153.

Rincon, M., Anguita, J., Nakamura, T., Fikrig, E., and RA Flavell. 1997. Interleukin (IL)-6 directs the differentiation of IL-4-producing CD4+ T cells. J Exp Med. 185(3): 461-469.

Schallig, H., van Leeuwen, M., Bernadina, W., and W Hendrikx. 1994. Serum antibody responses of Texel sheep experimentally infected with Haemonchus contortus. Res Vet Sci. 57: 63-68.

Schallig, H. 2000. Immunological responses of sheep to Haemonchus contortus. Parasitol. 120 Suppl: 72. 
Shakya, K., J. Miller, L. Lomax, and D. Burnett. 2011. Evaluation of immune response to artificial infections of Haemonchus contortus in Gulf Coast Native compared with Suffolk lambs. Vet. Parasitol. 181: 239-247.

Silva, KS., Sesti, Costa, RS., Silveira, TN., Caetano, BC., Horta, CV., Gutierrez, FRS., Guedes, PMM., Andrade, WA., De Niz, M., Gazzinelli, RT., Zamboni, DS., and JS Silva. 2016. Apoptosis-associated speck-like protein containing a caspase recruitment domain inflammasomes mediate IL-1B response and host resistance to Trypanosoma cruzi infection. J Immunol. 1203293.

Sher, A., Coffman, RL., Hieny, S. and Sheever AW. 1990. Ablation of eosinophil and IgE responses with anti-IL-5 or anti-IL-4 antibodies fails to affect immunity against Schistosoma mansoni in the mouse. J Immunol. 45(11): 3911-3916.

Sommers, KN. 2014. Immune related gene expression of parasite-resistant sheep during a Haemonchus contortus infection. Retrieved by ProQuest. 1555016.

Tacchini-Cottlier, F., Sweifel, C., Belkaid, Y., Mukankundiye, C., Vasei, M., Launois, P., Milon, G., and JA Louis. 2000. An immunomodulatory function for neutrophils during the induction of a CD4+ Th2 response in BALB/c mice infected with Leishmania major. J Immunol. 165(5): 2628-2636.

USDA. 2014. Wool report.

USDA. 2001. Part II: Reference of sheep health in the United States. In: USDA-APHIS (ed.), Fort Collins, CO.

Watanabe, N., Katakura K., Kobayashi, A., Okumura, K., and Z. Ovary. 1988. Protective immunity and eosinophilia in IgE-deficient SJA/9 mice infected with Nippostrongylus brasiliensis and Trichinella spiralis. Proc Natl Acad Sci USA. 85(12): 4460-4462.

Whelan, M., Harnett, MM., Houston, KM., Patel, V., Harnett, W., and RP Rigley. 2000. A filarial nematode-secreted product signals dendritic cells to acquire a phenotype that drives development of Th2 cells. J Immunol. 164: 6453-6460.

Wills-Karp M and Finkelman FD. 2008. Untangling the complex web of IL-4 and IL-13 mediated signaling pathways. Sci Signal. 1(51): 55.

Wooster, MJ., Woodgate, RG., and BF Chick. 2001. Reducaed efficacy of ivermectin, abamectin and moxidectin against field isolates of Haemonchus contortus. Aust Vet J. 79(12): 840-842.

Yoshimoto T., and WE Paul. 1994. CD4+, NK1.1 cells promptly produce interleukin 4 in response to in vivo challenge with anti-CD3. J Exp Med. 179(4): 1285-1295. 
Zhu, J., Huang, H., Guo, L., Stonehouse, T., Watson, CJ., Hu-Li, J., and WE Paul. 2000. Transient inhibition of interleukin 4 signaling by $T$ cell receptor ligation. J Exp Med. 192(8): 1125-134. 


\section{Chapter 2: Effects of culturing ovine PBMC with Haemonchus contortus antigen on IL-4 production and gene expression}

\section{Abstract}

St. Croix sheep produce an early and robust T helper type 2 response, critical for resistance to Haemonchus contortus. The mechanism of Th2 development in St. Croix sheep is not known, but is thought to be dependent on IL-4 signaling. The purpose of these studies were to compare immune responses of peripheral blood mononuclear cells, derived from either primed parasite-resistant St. Croix or primed parasite-susceptible Suffolk sheep, exposed to $H$. contortus larval or adult antigen. St. Croix-derived PBMC produced nearly twice as much IL-4 as Suffolk PBMC (823.57 pg/ml vs. $454.28 \mathrm{pg} / \mathrm{ml}$; respectively $P<0.05$ ) when cultured with $H$. contortus larval antigen for 6 hours. Despite a vast difference in IL-4 protein production, PBMC from St. Croix and Suffolk sheep did not have significantly different $(P=0.62)$ amounts of IL-4 gene expression compared to media control ( 2.88 vs. 1.15 fold change; respectively) after 6 hours of culture with larval antigen. The high-affinity IL-4 receptor (IL4Ra) was upregulated above media control in St. Croix-derived PBMC after 6 hours of culture with CLA, but was undetectable in Suffolkderived PBMC. St. Croix-derived PBMC also had increased Th2 gene expression IL-13 ( $P<0.05)$, IL-5 $(P<0.05)$ and MRC1 $(P<0.05)$ while Suffolk PBMC had increased IL-17 mRNA $(P<0.05)$. Suffolk-derived PBMC cultured with CLA and IL-4 protein were unable to achieve upregulation of Th2 related genes, while inhibition of STAT6 in St. Croix PBMC depleted their expression of IL4Ra. These data demonstrate a timely initiation of Th2 response produced by St. Croix sheep in response to $H$. contortus. Delayed upregulation 
of Th2 genes in Suffolk primed effector cells may further explain their susceptibility to $H$. contortus.

\section{Introduction}

Parasitic nematode infections are known to elicit a T helper type 2 (Th2) response

from their hosts, which are characterized by the production of interleukin-4 (IL-4), IL-5 and IL-13 and require STAT6 and GATA3 (Anthony et al., 2007). This is true in the case of Haemonchus contortus infection in sheep (LaCroux et al., 2006) whereas an increase in IL-4 and IL-13 gene expression has been observed in abomasal lymph nodes and mucosa during $H$. contortus infection (LaCroux et al., 2006).

Murine models clearly demonstrate that early upregulation of Th2 genes in the enteric region is associated with clearance of Heligmosmoides polygyrus bakeri infection (Svetic et a., 1993). In keeping with this finding, St. Croix hair sheep have been found to have increased IL-4 mRNA in the abomasum as early as day 3 post infection and increasing to day 7 and lower larval burdens, while Suffolk sheep do not have any detectable IL-4 mRNA and significantly increased larval burden during early $H$. contortus infection (Jacobs et al., 2016). In addition, increased levels of IL-4 are found in circulation of St. Croix sheep during $H$. contortus infection in association with lower FEC compared to Suffolk sheep (Jacobs et al., 2015).

The mechanism by which Th2 immunity is initiated in response to $H$. contortus is not fully understood. As antigenic components of $H$. contortus are unknown, studies using TCR specific cells are not possible. Therefore, whole worm antigen and non-specific lymphocyte populations are used to observe immune development. Thus far, Th2 activation in an in vitro culture of ovine PBMC with $H$. contortus has not been described 
in the literature. Therefore, these studies sought both to validate a protocol for in vitro culture of ovine PBMC from both parasite resistant and susceptible sheep with $H$. contortus larval and adult antigens and to compare their effector response by cytokine production.

\section{Materials and Methods}

\section{Animals and experimental design}

Three primed, uninfected adult St. Croix and three primed, uninfected adult Suffolk sheep were used for blood collection. St. Croix and Suffolk animals used in these experiments were uninfected adults. All animals were born in an elevated barn with expanded metal flooring and were never on pasture or naturally infected with gastrointestinal trichostrongylid parasites. Each animal was previously orally administered more than three separate experimental monoinfections with $10,000 \mathrm{~L}_{3} H$. contortus infections. Animals were previously administered an oral dose of levamisole hydrochloride (AgriLabs, St, Joseph, MO) at a dosage of $8 \mathrm{mg} / \mathrm{kg}$ of body weight. At the time of experimentation, all sheep had an undetectable fecal egg count (FEC) as measured by the Modified McMaster's Technique (Whitlock, 1948). Whole blood was collected from each animal, PBMC were separated and cultured in 96 well round bottom cell culture plates at a concentration of 300,000 cells / well and 12 wells per treatment per animal. Treatments used were Crude Larval Antigen (CLA), Crude Worm Antigen (CWA), STAT6 inhibitor (STAT6inh) and complete media control (CM) and cells were cultured for $2,4,6,24,48$ or 72 hours. 


\section{Haemonchus contortus larval culture}

Larvae were obtained by fecal culture followed by the Baermann Technique (Zajac and Conboy. 2012). Feces containing $H$. contortus eggs were collected from chronically infected adult sheep housed in the elevated floor barn. Feces were mixed with sterile peat moss and activated charcoal, and the mixture was incubated for one week at $30^{\circ} \mathrm{C}$. Larvae were Baermannized and diluted to 1,000 L3 larvae / ml in PBS (pH 7.4). Each lamb was given an oral inoculum of $10 \mathrm{ml}$ of diluted $H$. contortus larvae.

\section{Antigen Preparation}

A one $\mathrm{mL}$ centrifuged pellet of $\mathrm{L}_{3} H$. contortus larvae was homogenized on ice using a tissue homogenizer. Larval lysate was centrifuged at $15,000 \times g$ at $4^{\circ} \mathrm{C}$ for $1 \mathrm{hr}$. Supernatant was removed and sterile filtered through a $0.22 \mu \mathrm{m}$ syringe filter. Sterilefiltered supernatant protein concentration was determined using micro-BCA assay (Pierce, Rockford, IL). After protein quantification, protease inhibitor cocktail (Sigma Aldrich, St. Louis, MO) was added at a rate of $1 \mu \mathrm{l}$ cocktail per $\mu \mathrm{g}$ of protein. Crude worm antigen (CWA) was prepared as described in Bowdridge et al., (2013). Lysate was centrifuged at $15,000 \times g$ at $4^{\circ} \mathrm{C}$ for $1 \mathrm{hr}$, supernatant was removed and sterile filtered through $0.22 \mu \mathrm{m}$ syringe filter. Sterile-filtered supernatant protein concentration was determined using micro-BCA assay (Thermo Fisher Scientific, Waltham, MA) . After protein quantification, protease inhibitor cocktail (Sigma Aldrich, St. Louis, MO) was added at a rate of $1 \mu \mathrm{l}$ of cocktail per $\mu \mathrm{g}$ of protein. Crude larval and worm antigen were aliquoted into $1.5 \mathrm{ml}$ microcentifuge tubes and stored at $-80^{\circ} \mathrm{C}$ until further use. 


\section{Peripheral blood mononuclear cell separation}

Whole blood was collected by jugular venipuncture and placed into EDTA-treated vacutainer tube. Whole blood was centrifuged at $700 \times g$ for 20 minutes at $R T$ to separate white blood cells. Buffy coat was isolated and mixed with $1 \mathrm{~mL}$ of sterile PBS (Corning, Manassas, VA). Red blood cells were lysed using $3 \mathrm{~mL}$ of ACK lysis buffer (Lonza, Alpharetta, GA) and re-suspended with sterile PBS. The solution was centrifuged at 112 $x g$ for 5 minutes at RT to pellet WBC. Cells were suspended in $3 \mathrm{~mL}$ of sterile PBS and layered over $5 \mathrm{~mL}$ of lymphocyte separation media (density $=1.077-1.080 \mathrm{~g} / \mathrm{ml}$ ) (Corning, Manassas, VA) and centrifuged at $400 \times g$ for 20 mins to separate peripheral blood mononuclear cells (PBMC). Cells from the transition layer were removed and resuspended in sterile PBS. Cells were microscopically verified to be $>99 \%$ PBMC using Wright stain (Camco, Ft. Lauderdale, FL) and quantified using a TC20 automated cell counter (Bio-Rad, Hercules, CA).

\section{In vitro cell culture}

Peripheral blood mononuclear cells were diluted to $5 \times 10^{6}$ in complete media consisting of RPMI 1640 (GE Healthcare, Marlborough, MA) with 0.1\% FBS (Corning, Manassas, VA) and penicillin/streptomycin/neomysin antibiotic mixture (Fisher Scientific, Waltham, MA). Cells were added to a 96 well round bottom cell culture plate (BD Biosciences, San Jose, CA) at a concentration of 300,000 cells / well. Twelve wells were used per animal per treatment (CLA, CWA) with cells in complete media (CM) as a control. Cells were incubated for indicated times at $37^{\circ} \mathrm{C}$ and $5 \% \mathrm{CO}_{2}$. Cells and supernatant were removed after incubation. Cells were immediately processed for RNA isolation and supernatant was stored at $-80^{\circ} \mathrm{C}$ for ELISA. 


\section{Cytokine ELISA}

All cytokine concentrations were determined per manufacturer's instructions (MyBioSource, San Diego, CA). All samples were analyzed in duplicate and absorbance was read at $450 \mathrm{~nm}$. Briefly, IL-4 was quantified by ovine-specific ELISA kit (MyBioSource, San Diego, CA). Undiluted serum was analyzed in duplicate for each animal and the assay was performed per manufacturer's protocol. Absorbance was read at $450 \mathrm{~nm}$ and raw absorbance values for samples and standards were adjusted for blank absorbance. Concentration of IL-4 was calculated using a standard curve with a detection range of $6.25-400 \mathrm{pg} / \mathrm{ml}$, coefficient of variation (CV) of inter and intra-assay was less than $10 \%$. Raw absorbance values for samples and standards were adjusted for blank absorbance.

\section{RNA isolation and cDNA preparation}

RNA was isolated using the illustra RNAspin kit (GE Healthcare, Marlborough, MA). All cells from each animal within treatment (12 wells) were pooled for RNA extraction. RNA quality and concentration was measured using Take3 microvolume plate (BioTek, Winooski, VT) and samples with a $260: 280$ ratio $\geq 1.8$ were accepted and diluted in $13 \mu \mathrm{L}$ of DEPC-treated water to a total concentration of $1.8 \mu \mathrm{g}$. Synthesis of cDNA was accomplished by creating a master mix including $2.5 \mu \mathrm{L}$ of $2.5 \mathrm{nM}$ dNTP (GE Illustra, Buckinghamshire, UK), 5.0 $\mathrm{L}$ 5X reverse transcriptase buffer (Life Technologies, Burlington, ONT Canada), 2.0 $\mathrm{LL}$ 0.01M DTT (Life Technologies, Burlington, ONT Canada), $0.5 \mu \mathrm{L}$ RNasin (Promega, Madison, $\mathrm{WI}$ ), and $2.0 \mu \mathrm{L}$ random hexamer primers (Life Technologies, Burlington, ONT). Master mix $(12 \mu \mathrm{L})$ was added to $13 \mu \mathrm{L}$ of RNA and samples were denatured at $70^{\circ} \mathrm{C}$ for 5 minutes then chilled at $4^{\circ} \mathrm{C}$ for 5 minutes using a 
T100 thermal cycler (Bio-Rad, Hercules, CA). Then $1 \mu \mathrm{L}$ of SuperScript ${ }^{\mathrm{TM}} \|$ reverse transcriptase (Life Technologies, Burlington, ONT Canada) was added to each sample finishing the reverse transcription reaction conditions of $37^{\circ} \mathrm{C}$ for 60 minutes, $90^{\circ} \mathrm{C}$ for 5 minutes, and then $4^{\circ} \mathrm{C}$ for 5 minutes. Final cDNA preparations were stored at $-20^{\circ} \mathrm{C}$.

\section{Primer design and efficiency}

Primer design was based on known mRNA sequences in the NCBI database. For each candidate gene, primers were selected using Primer-3 software (Rozen and Skaletsky, 2000). The following changes were applied to the default program parameters: product range 80-120 bp; primer $T_{\mathrm{m}} 59-61{ }^{\circ} \mathrm{C}$; primer $\mathrm{GC} \%$ 40-60; max selfcomplementarity 3; max 3' self-complementarity 1; max poly-x 3. Genes associated with GenBank accession numbers and sequence of primers used in qPCR are shown in Jacobs et al., 2016. With the exception of interleukin-5 (Robinson et al., 2011), original primers were used and were published (Jacobs et al., 2016). Efficiency was derived from the slope of the regression line fitted to a subset of baseline-corrected data points in the log-linear phase using LinRegPCR (Ramakers et al., 2003). Efficiency for each primer

was higher than $(1+E)=1.96$. Melting curve analysis resulted in only one well-defined peak per reaction indicating a sole PCR product being amplified. Melting temperature (Tm) of products were consistent with theoretical Tm of the expected PCR products. Only one band was visualized after agarose gel electrophoresis of all amplified products (data not shown).

\section{Quantitative PCR}

Samples were analyzed in triplicate using the CFX96 system (Bio-Rad, Hercules, CA). Reaction was carried out in a total volume of $20 \mu$, containing $10 \mu \mathrm{L}$ SYBR Select 
Master Mix (Life Technologies, Burlington, ONT Canada), $1.2 \mu \mathrm{L}$ of each forward and reverse primers, $2 \mu \mathrm{L} 10 \mathrm{ng} / \mu \mathrm{L}$ diluted cDNA template, and 5.6 $\mu \mathrm{L}$ DEPC-treated water. qPCR Reaction conditions were: $50^{\circ} \mathrm{C}$ for 10 minutes and an initial denaturation at $95^{\circ} \mathrm{C}$

for 5 minutes followed by 40 cycles of denaturation at $95^{\circ} \mathrm{C}$ for 10 seconds and extension for 30 seconds at $60^{\circ} \mathrm{C}$. The relative fold change in gene expression of candidate genes was done using the $2^{-\Delta \Delta C t}$ method (Livak and Schmittgen, 2001). The obtained Ct values were used to calculate $\Delta \mathrm{Ct}$ values for genes of interest [Ct (test) - Ct (reference)]. Reference gene used for normalization was GADPH.

\section{Statistical Analysis}

Data were analyzed using SigmaPlot (Systat Software, Inc., San Jose, CA). Statistical analysis for qPCR data was based on $\log _{2}(\Delta C t)$ values, but results were reported as fold-changes from the reference class, defined as the value for each breed type at day 0 . Preliminary analyses revealed that the blocking variable did not significantly affect expression. Data were thus analyzed using a two-way analysis of variance (ANOVA) with main effects of breed, time, and breed $x$ time interaction. Means were compared using a Bonferroni test statistic; differences with $P \leq 0.05$ were considered statically significant.

\section{Results}

\section{Sheep PBMC response to $\mathrm{H}$. contortus antigen in vitro}

Peripheral blood mononuclear cells from St. Croix (STC) and Suffolk (SUF) were cultured with $10 \mu \mathrm{g} / \mathrm{ml}$ of concanavalin A (CONA), crude larval antigen (CLA), crude worm antigen (CWA) and compared to complete media (CM) control for 6, 24, 48 or 72 hours and supernatant was analyzed for IL-4 protein by ELISA. PBMC from both STC 
and SUF were able to generate IL-4 when stimulated with CONA (Figure 1A). Data has been adjusted by subtracting complete media values. PBMC from STC generated a small amount of IL-4 $(5.13 \mathrm{pg} / \mathrm{ml})$ at 6 hours when cultured with CONA and did not generate appreciable IL-4 at any time point afterward (Figure 1A). PBMC from SUF did not produce detectable IL-4 until 72 hours of culture with CONA (Figure 1A) at which point, $17 \mathrm{pg} / \mathrm{ml}$ IL-4 was produced.

PBMC from STC sheep produced $17.2 \mathrm{pg} / \mathrm{ml} \mathrm{IL-4}$ after 6 hours of culture with $H$. contortus crude larval antigen (CLA) and produced no detectable IL-4 at 24,48 or 72 hours (Figure 1B). SUF PBMC did not generate IL-4 in response to CLA until 48 hours of culture, at which time $2.4 \mathrm{pg} / \mathrm{ml} \mathrm{IL-4}$ was generated, which increased to $5.7 \mathrm{pg} / \mathrm{ml}$ at 72 hours (Figure 1B), which indicates a delay in response to $H$. contortus larval antigen. Similarly, STC PBMC generated $13.78 \mathrm{pg} / \mathrm{ml}$ IL-4 in response to $H$. contortus crude worm antigen (CWA) at 6 hours of culture and did not produce detectable IL-4 at any other time point (Figure 1C). There was no detectable IL-4 produced by SUF PBMC in response to $H$ contortus CWA until 72 hours of culture, at which point, $11.28 \mathrm{pg} / \mathrm{ml} \mathrm{IL-4}$ was produced (Figure 1C).

When increasing CLA and CWA concentration to $20 \mu \mathrm{g} / \mathrm{ml}$, SUF PBMC produced $454.28 \mathrm{pg} / \mathrm{ml} \mathrm{IL-4} \mathrm{(Figure} \mathrm{2A).} \mathrm{IL-4} \mathrm{produced} \mathrm{by} \mathrm{STC} \mathrm{PBMC} \mathrm{at} 6$ hours was nearly double the amount of SUF at $823.57 \mathrm{pg} / \mathrm{ml}$ (Figure 2). Interestingly, neither STC or SUF produced any detectable IL-4 in response to culture with CWA (Figure 2). Again, this indicates a delay in response to $H$. contortus antigen in SUF PBMC. 


\section{Gene expression of sheep PBMC exposed to crude larval antigen}

When analyzed by qPCR, St. Croix and Suffolk PBMC upregulated similar amounts of II4 transcript at 2, 4 and 6 hours of culture with $H$. contortus CLA (Figure 3A). However, St. Croix PBMC had slightly increased I/4ra above complete media control at 6 hours of culture while Suffolk PBMC did not have detectable I/4ra at 2, 4 or 6 hours of culture (Figure 3B). St. Croix PBMC significantly up-regulated $I / 13(P<0.05$, Figure 3C), II5 $(P<0.05$, Figure 3D) and $\operatorname{Mrc1}(P<0.01$, Figure 3E) at 6 hours of culture with $H$. contortus larval antigen. Suffolk PBMC up-regulated $/ 117$ at 2, 4 and 6 hours of culture as compared to St. Croix PBMC $(P<0.05$, Figure 3F). Neither St. Croix or Suffolk PBMC had upregulated II12 at any time point (Figure 3G).

PBMC from naïve St. Croix and Suffolk lambs had similar amounts of I/4 upregulation as primed PBMC at 4 and 6 hours of culture with larval or adult $H$. contortus antigen (Figure 4A). However, naïve St. Croix PBMC showed no upregulation of II4ra to larval or adult $H$. contortus antigen at 4 or 6 hours of culture (Figure 4B), unlike their primed counterparts (Figure 3B). In fact, I/4ra from naive St. Croix PBMC was lower than media control baseline in response to CLA at 4 hours of culture and did not exceed baseline in response to larval or adult antigen (Figure 4B). Similarly, II4ra from naïve Suffolk PBMC did not rise significantly above baseline in response to larval or adult $H$. contortus antigen at either 4 or 6 hours of culture (Figure 4B).

IL-13 mRNA was not found to be upregulated above media control in either naïve St. Croix or Suffolk PBMC in response to either CLA or CWA at 4 or 6 hours of culture (Figure 4C). IL-5 mRNA in naïve St. Croix PBMC was increased slightly above media control after 4 hours of infection with CLA, but was decreased below control at 6 hours 
(Figure 4D). No other PBMC had increase $1 / 5$ in response to CLA or CWA at 4 or 6 hours (Figure 4D).

Naïve St. Croix PBMC showed slight upregulated of Mrc1 in response to CWA at 4 hours of culture, but not significantly (Figure 4E). Naïve St. Croix PBMC had no upregulation of Mrc1 at any time of culture to CLA or CWA (Figure 4E). Additionally, naïve Suffolk PBMC did not show upregulation of Mrc1 to either larval or adult antigen at 6 hours of infection (Figure 4E).

Interestingly, IL-17 mRNA was upregulated in naïve St. Croix PBMC in response to both larval and adult $H$. contortus antigen at 6 hours of culture (Figure 4F). Naïve St. Croix and Suffolk PBMC did not have increased I/17 in response to CLA or CWA at 4 hours of culture. In addition, Suffolk PBMC did not have increased I/17 in response to CLA or CWA at 6 hours of infection (Figure 4F), as opposed to their primed counterparts (Figure 3F).

Finally, naïve St. Croix PBMC had slightly increased I/12 above meda control in response to CLA and CWA at 4 hours of culture, while naïve Suffolk PBMC had decreased II12 (Figure 4G). At 6 hours of culture, neither naïve St. Croix or Suffolk PBMC had increased I/12 in response to CLA or CWA (Figure 4G).

\section{Exogenous supplementation of Suffolk PBMC with IL-4 protein}

Given the disparity of IL-4 protein produced by St. Croix and Suffolk PBMC exposed to $H$. contortus CLA (Figure 2) despite similar levels of IL-4 mRNA (Figure 3A), Suffolk PBMC were supplemented with undiluted IL-4-containing supernatant produced by St. Croix PBMC in the amount of $823.57 \mathrm{pg} / \mathrm{ml}$ (Figure 2). To determine if lack of Th2 activation by Suffolk PBMC was a function of lack of IL-4 protein signal, primed Suffolk 
PBMC were cultured with crude larval antigen, crude worm antigen or crude larval or worm antigen with supernatant from St. Croix PBMC containing measured IL-4 protein.

Supplementation of media with IL-4 did not increase IL-4 mRNA in Suffolk PBMC compared to PBMC cultured with only CLA or CWA at 4 or 6 hours (Figure 5A). Again, II4ra was not increased above media control in primed Suffolk PBMC cultured with CLA or CWA at 4 or 6 hours (Figure 5B). Additionally, IL-4 supplementation was not successful in causing the upregulation of IL4Ra mRNA in response to either CLA or CWA at either 4 or 6 hours of culture when compared to culture without IL-4 supplementation or media control (Figure 5B). Similarly, IL-4 supplementation was not successful in causing upregulated of any other tested Th2 related genes. IL-13 mRNA in primed Suffolk PBMC cultured with CLA, CWA or IL-4 supplemented CLA or CWA was not increased above media control at 4 or 6 hours (Figure 5C). IL-4 supplemented PBMC cultured with CLA and CWA had significantly down-regulated $I / 5$ at 6 hours of culture compared to PBMC cultured with non-supplemented CLA or CWA (Figure 5D).

Culture of PBMC with CWA and IL-4 supplementation resulted in decreased IL-17 mRNA at 4 hours, though was resolved at 6 hours of culture (Figure 5E). At 6 hours of infection, supplementation with IL-4 with CLA culture resulted in decreased IL-17 transcript in Suffolk PBMC (Figure 5E). Similarly, decrease in Mrc1 was observed during IL-4 supplemented CLA culture at 4 and 6 hours of culture (Figure 5F). Decrease in Mrc1 was also observed in IL-4 supplemented CWA culture at 6 hours compared to nonsupplemented CWA culture (Figure 5F). 


\section{Pharmacological inhibition of STAT6 in St. Croix PBMC cultured with $\mathrm{H}$. contortus crude larval antigen}

Signaling of IL-4 through IL4Ra results in the phosphorylation and dimerization of the transcription factor signal transducer and activator of signal 6 (STAT6) followed by its translocation to the nucleus (Hou et al., 1994). As such, STAT6 was inhibited pharmacologically (Axon, Groningen, Netherlands) St. Croix PBMC cultured with CLA to determine its effects on IL4Ra gene expression. Use of a STAT6 inhibitor in the amount of $100 \mathrm{nM}(\mathrm{S} 6 \mathrm{INH} 1)$ or $10 \mathrm{nM}(\mathrm{S} 6 \mathrm{INH} 2)$ successfully decreased IL-4 mRNA in St. Croix PBMC cultured with CLA at 6 hours (Figure 6). PBMC from one of three primed St. Croix animals did not produce any detectable IL-4 mRNA when cultured with 100 nM STAT6 inhibitor. In addition, the use of 100 nM STAT6 inhibitor significantly decreased the expression of IL4Ra in St. Croix PBMC cultured with CLA, decreasing it to the level of IL4Ra expression in Suffolk PBMC cultured with CLA $(P<0.05$, Figure 6$)$.

\section{Discussion}

Early response to parasite infection is critical to effective expulsion. Recognition, reaction and expulsion of larval prevents substantial establishment of adult worms, possibly leading to a more manageable level $H$. contortus infection. Studies with enteric helminth parasites in mice indicate that early response leads to expulsion of worms. Much like in our results, mice infected with $H$. polygyrus show upregulation of Th2 related genes IL-5 and IL-9 by 6 hours of infection in local secondary lymphoid tissues (Svetic, et al., 1993). Similarly, the immune response to $H$. contortus by parasite resistant St. Croix sheep indicates an early response in vivo. St. Croix sheep generate a greater cellular and 
humoral response to $H$. contortus infection, which is associated with lower fecal egg count (Bowdridge et al., 2013).

Data describing the response of PBMC to parasite antigens is sparce. In these studies, St. Croix PBMC respond in a Th2 manner earlier than Suffolk PBMC in response to both larval and adult antigen. The onset of IL-4 production by Suffolk PBMC was delayed by three days, which mimics in vivo findings of delayed immune response by Suffolk sheep in response to $H$. contortus. St. Croix sheep upregulate IL-4 mRNA in the abomasum as early as 3 days after experimental infection (Jacobs, 2016), while IL-4 mRNA is not detectable in Suffolk sheep.

When doubling the amount of antigen used, Suffolk PBMC were able to generate IL-4 after 6 hours of culture with CLA, while St. Croix PBMC generated double the amount of IL-4. This again illustrates a deficiency in the ability of Suffolk to respond to $H$. contortus as compared to St. Croix, which may indicate Suffolk sheep may be more easily overwhelmed by a large infection of $H$. contortus, possibly due to lack of immune response, especially as these cells were derived from animals that were previously primed and should have immunological memory.

Gene expression analysis of St. Croix and Suffolk PBMC cultured with CLA and CWA revealed that expression of il4 was not different, despite significant difference in IL4 protein produced by St. Croix and Suffolk PBMC,. However, Suffolk PBMC fail to upregulate IL-4Ra mRNA. In addition to upregulation of IL4Ra by St. Croix PBMC, IL-13 was also upregulated in response to CLA at 6 hours of culture. IL-13 is a cytokine responsible for smooth muscle contractility in the gut (Terez, et al., 2014) and has been implicated in its necessity for parasite expulsion, along with IL4R a and STAT6 (Urban et 
al., 1998). Lack of upregulation of IL-13 in Suffolk PBMC could contribute to the inability of Suffolk sheep to expel $H$. contortus larvae.

Eosinophilia is classically associated with helminth parasite infection (Behm and Ovington, 2000) and IL-5 acts as a chemoattractant and activator of eosinophils (Lopez et al., 1986). Attraction of eosinophils to the site of parasite infection aids in early helminth expulsion (Anthony, 2007) and greater eosinophilia is associated with $H$. contortus resistant sheep (Terefe et al., 2009). In addition to having increased eosinophils, parasite resistant sheep had decreased worm burdens, however differences in abomasal gene expression were not found (Terefe et al., 2009). Notably these data were not collected until 16 days of infection with $H$. contortus. IL-5 gene expression is detectable in the abomasum of St. Croix sheep on days 3, 5 and 7 of $H$. contortus infection, while not detectable on any of these days in Suffolk sheep (Jacobs et al., 2016). Similarly to in vivo data, these in vitro data show St. Croix PBMC upregulate IL-5 in response to CLA at 6 hours of culture.

Alternatively activated macrophages are associated with wound healing (Gratchev, et al., 2001). Parasite infections are typically associated with tissue damage, both from direct damage from the parasite and from increases in eosinophils, neutrophils, mast cells and basophils. Degranulation of these cells contribute to parasite expulsion as well as pathologic inflammation (Allen and Sutherland, 2014), as such alternatively activated macrophages are associated with tissue remodeling during helminth infection (Kreider et al., 2007). Mannose Receptor, C Type 1 (MRC1 / CD206) is a marker of alternatively activated macrophages, which was found to be upregulated in St. Croix PBMC in response to culture with $H$. contortus larval antigen at 6 hours. In combination 
with IL-13 gene expression suggests the presence of alternatively activated macrophage phenotype of cells in this culture system.

Lack of upregulation of Th2 genes by naïve St. Croix PBMC indicate the importance of immunology memory to $H$. contortus antigen. IL-4 mRNA is upregulated above media control in naïve St. Croix and Suffolk PBMC. Recent research has indicated that naïve T cells produce IL-4 in the absence of IFN- $\gamma$ and IL-12 (Noben-Trauth et al., 2016) and our data show no upregulation of IL-12.

Due to significantly different IL-4 protein production by St. Croix and Suffolk PBMC, Suffolk PBMC were supplemented with IL-4-containing supernatant from St. Croix PBMC. IL-4 supplementation of Suffolk PBMC was not sufficient to stimulate Th2 activation, indicating lack of Th2 activation is not the result of insufficient IL-4 protein. Therefore, we evaluated the function of STAT6 in activation of Th2 genes in St. Croix PBMC. Polymorphisms in STAT6 have been documented to vary in breeds of cattle (Rincon et al., 2009). Production of IL-4 is not solely dependent on STAT6, however activation of Th2 genes does require STAT6 (Kaplan et al., 1999). As Suffolk PBMC are able to generate IL-4, but not activate Th2, the possibility exists there may be polymorphisms in STAT6 in sheep. Inhibition of STAT6 reduced IL4Ra mRNA in St. Croix PBMC cultured with $H$. contortus larval antigen to the level observed in Suffolk PBMC. STAT6 genes in each breed should be sequenced to determine the presence of single nucleotide polymorphisms and their contribution to parasite resistance or susceptibility.

The development of the in vitro ovine PBMC culture system provides a new way to study immune development on the cellular level, which have not been previously studied in the context to $H$. contortus antigen. Use of this system, enabled discovery of 
deficiencies in Th2 development in a small population of cells derived from $\mathrm{H}$. contortus primed Suffolk animals. The development of this system will be useful in determining specific pathways activated in St. Croix sheep allowing the development of Th2 using gene analysis by $\mathrm{qPCR}$ and RNA-Seq. 


\section{Literature Cited}

Allen, JE and TE Sutherland. 2014. Host protective roles of type 2 immunity: parasite killing and tissue repair, flip sides of the same coin. Semin Immunol. 26(4): 329340.

Anthony, RM., Rutitzky, LI., Urban, JR., Stadecker, MJ., and WC Gause. 2007. Protective immune mechanisms in helminth infection. Nat Rev Immunol. 7(12): 975-987).

Behm, CA and KS Ovington. 2000. The role of eosinophils in parasitic helminth infections: insights from genetically modified mice. Trends Parasitol. 16(5): 202209).

Bowdridge, S., Mackinnon K., McCann J., Zajac, A., and D. Notter. 2013. Hair-type sheep generate an accelerated and longer-lived humoral immune response to Haemonchus contortus infection. Vet. Parasitol. 196: 172-178.

Gratchev, A., Guillot, P., Hakiy, N., Politz, O., Orfanos, CE., Schledzewski, K., and S. Goerdt. 2001. Alternatively activated macrophages differentially expression fibronectin and its splice variants and the extracellular matrix protein $\beta$ IG-H3. Scan J Immunol. 53(4): 386-392.

Hou, J., Schindler, U., Henzel, WJ., Ho, TC., Brasseur, M., and SL McKnight. 1994. An interleukin-4-induced transcription factor: IL-4 Stat. Science. 265(5179): 17011706.

Jacobs, JR., Greiner, SP., and SA Bowdridge. 2015. Serum interleukin-4 (IL-4) production is associated with lower fecal egg count in parasite-resistant sheep. Vet Parasitol. 211(1-2): 102-5.

Jacobs, JR., Sommers, KN., Zajac, AM., Notter, DR., and SA Bowdridge. 2016. Early IL-4 gene expression in abomasum is associated with resistance to Haemonchus contortus in hair and wool sheep breeds. Parasit Immunol. 38(6): 333-339.

Kaplan, MH., Wurster, AL., Smiley, ST., and MJ Grusby. 1999. Stat-6 dependent and independent pathways for IL-4 production. J Immunol. 163: 6536-6540.

Kreider, T., Anthony, RM., Urban, JF Jr., and WC Gause. 2007. Alternatively activated macrophages in helminth infections. Curr Op Immunol. 19(4): 448-453.

Lacroux, C., T. Nguyen, O. Andreoletti, F. Prevot, C. Grisez, J.-P. Bergeaud, L. Gruner, J.-C. Brunel, D. Francois, P. Dorchies, and P. Jacquiet. 2006. Haemonchus contortus (Nematoda: Trichostrongylidae) infection in lambs elicits an unequivocal Th2 immune response. Vet. Res. 37: 607-622. 
Lopez, AF., Begley CG., Williamson, DJ., Warren, DJ., Vadas, MA and CJ Sanderson. 1998. Muring eosinophil differentiation factor. An eosinophil-specific colonystimulating factor with activity for human cells. J Exp Med. 163(5): 1085-1099.

Noben-Trauth, N., Hu-Li, J., and WE Paul. 2016. Conventional, naïve CD4 ${ }^{+}$T cells provide an initial source of IL-4 during Th2 differentiation. J Immunol. 165(7): 36203625.

Rincon, G.,, Farber, EA., Farber, CR., Nkrumah, JD., and JF Medrano. 2009. Polymorphisms in the STAT6 gene and their association with carcass traits in feedlot cattle. Anim Genet. (40(6): 878-882.

Svetic, A., Madden, KB., Zhou, PL., Katona, IN., Finkelman, FD., Urban, JF and WC Gause. 1993. A primary intestinal helminthic infection rapidly induces a gutassociated elevation of Th2-associated cytokines and IL-3. J Immunol. 150(8 Pt 1): 3434-3441.

Terez, SD., Notari, L., Sun, R., and A Zhao. 2012. Mechanisms of smooth muscle responses to inflammation. Neurogastroenterol Motil. 29(9): 802-811.

Terefe, G., Lacroux, C., Prevot, F., Grisez, C., Bergeaud, JP., Dorchies, P., Foucras, G., and P. Jacquiet. 2009. Eosinophils in Haemonchus contortus-infected resistant and susceptible breeds of sheep: abomasal tissue recruitment and in vitro functional state. Vet Parasitol. 165(1-2): 161-164.

Urban, JF Jr., Noben-Trauth, N., Donaldson, DD., Madden, KB., Morris, SC., Collins, M., and FD Finkelman. 1998. IL-13, IL-4Ralpha, and Stat6 are required for the expulsion of the gastrointestinal nematode parasite Nippostrongylus brasiliensis. Immunity. 8(2): 255-264.

Whitlock, HV. 1948. Some modifications of the McMaster helminth egg-counting technique apparatus. J Counc Sci Ind Res. 21:177-180. 
Figures

Figure 1
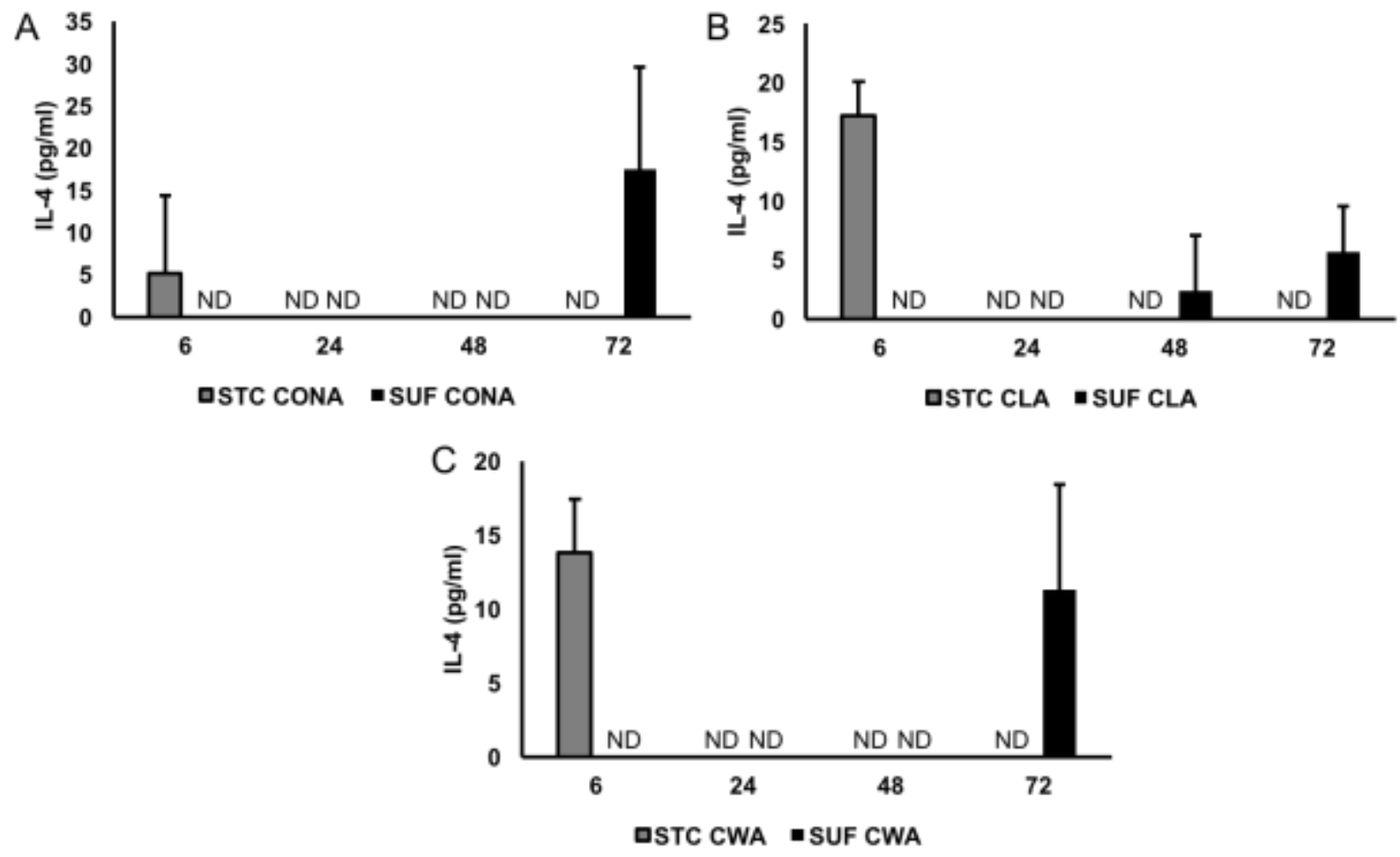

Figure 1: Sheep PBMC generate IL-4 in response to culture stimulants. St Croix (STC) and Suffolk (SUF) peripheral blood mononuclear cells (PBMC) were cultured with $10 \mu \mathrm{g} / \mathrm{ml}$ CONA (A), CLA (B) or CWA (C) for $6,24,48$ or 72 hours and IL-4 in cell supernatants were measured by ELISA. ND = no detection. Error bars $=$ standard error of the mean. 
Figure 2

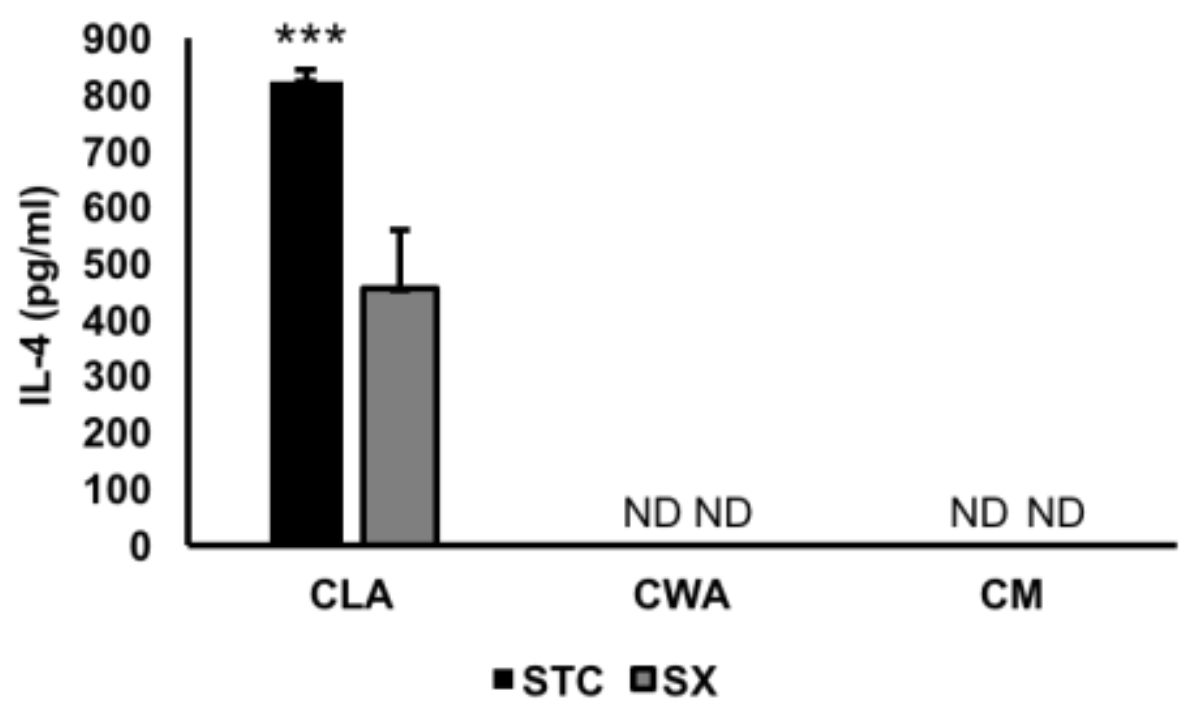

Figure 2: STC generate twice as much IL-4 in response to $20 \mu \mathrm{g} / \mathrm{ml} H$. contortus crude larval antigen after 6 hours of culture. STC and SUF PBMC were cultured with $20 \mu \mathrm{g} / \mathrm{ml}$ CLA, CWA or complete media control. IL-4 protein production was determined by ELISA. ND = no detection. Error bars $=$ standard error of the mean. ${ }^{* *} P<0.0001$. 
Figure 3
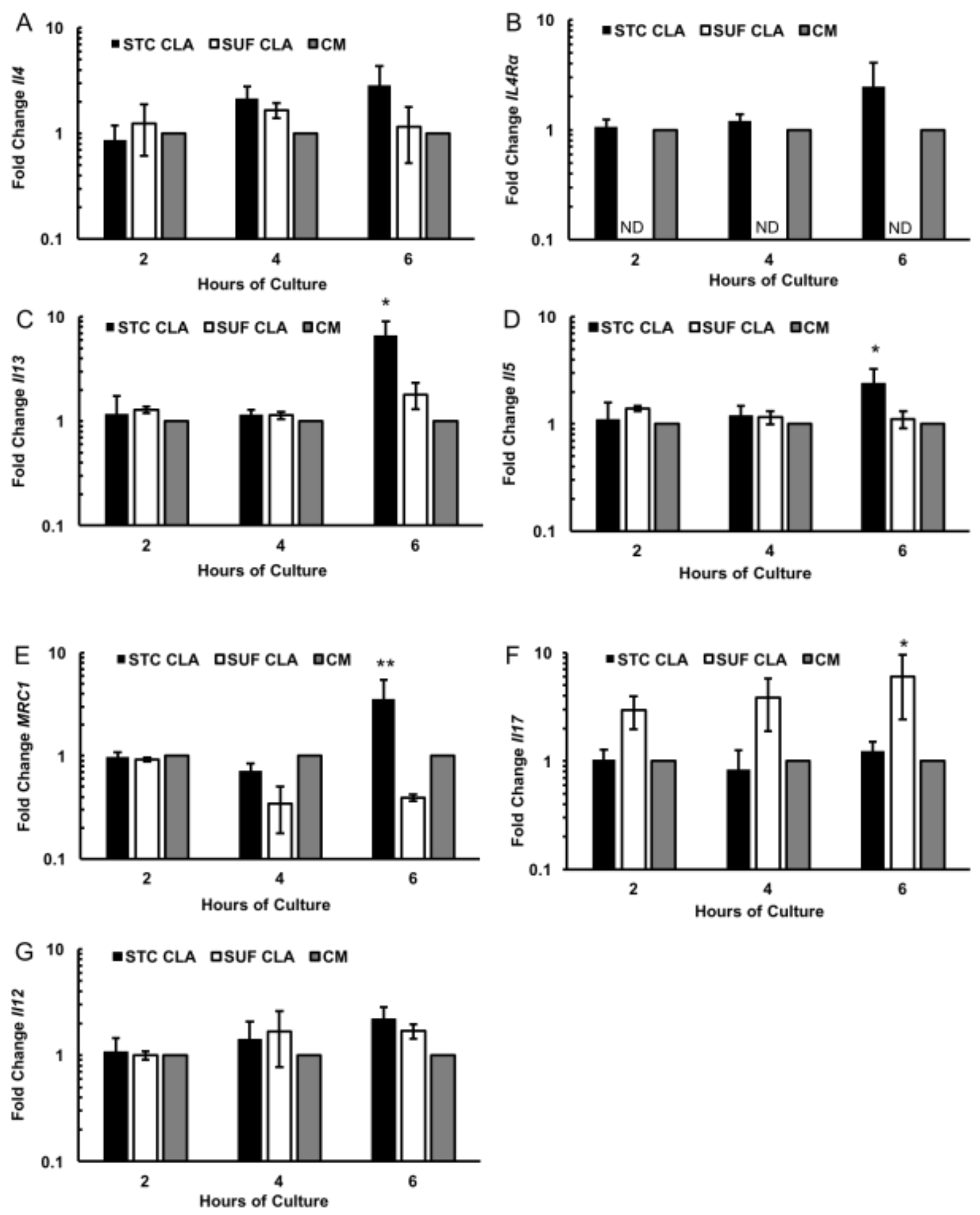
Figure 3: mRNA analysis of primed St. Croix and Suffolk PBMC by qPCR in reponse to culture with $\boldsymbol{H}$.

contortus crude larval antigen. PBMC from primed St. Croix and Suffolk PBMC incubated with $20 \mu \mathrm{l}$ crude larval antigen for 2, 4 or 6 hours and gene expression of II4 (A), I4ra (B), II13 (c), II5 (D), Mrc1 (E), II17 (F) or II12 (G) was performed by qPCR. Error bars $=$ SEM. ${ }^{*} P<0.05$; ${ }^{* *} P<0.001$. 
Figure 4
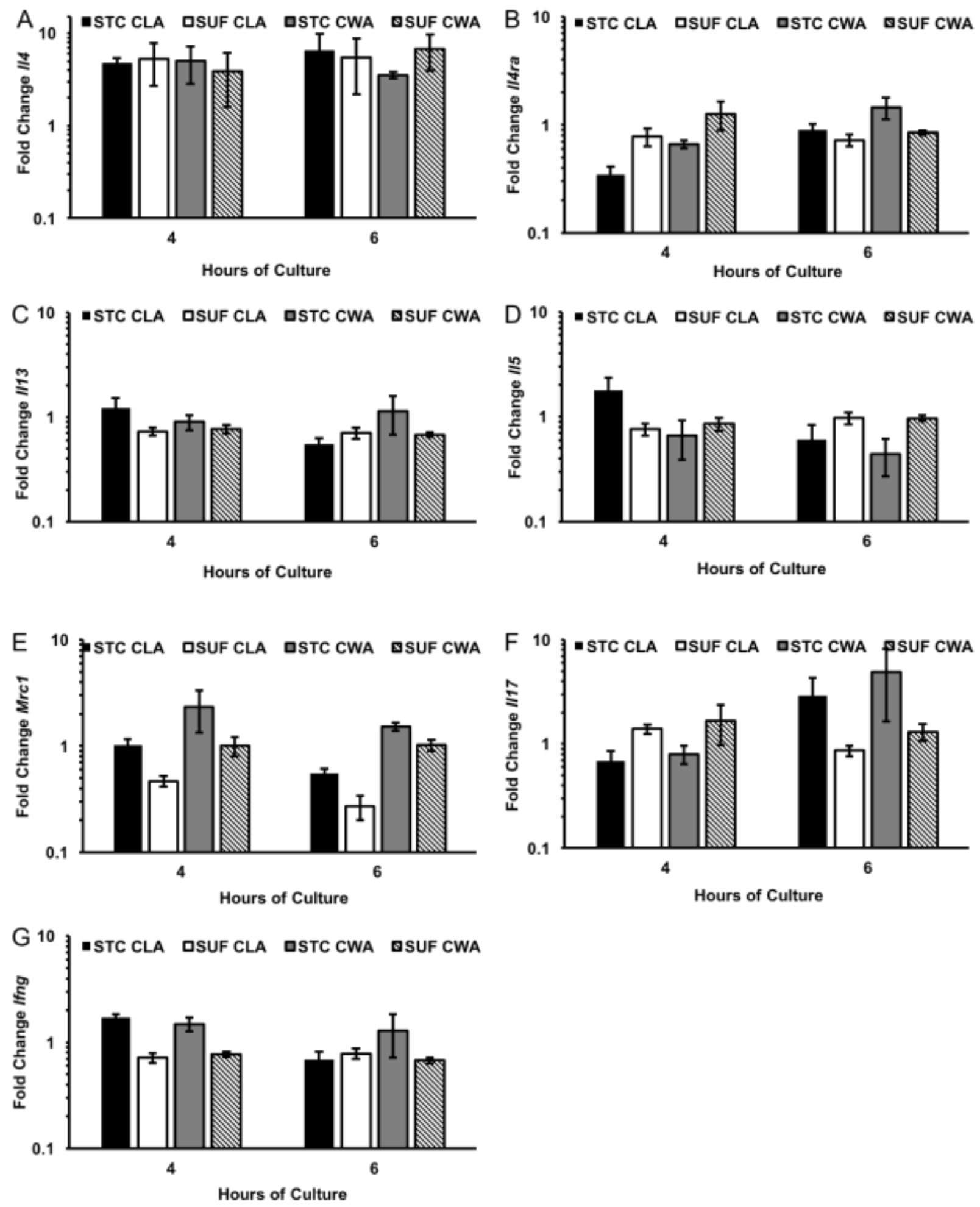
Figure 4: mRNA analysis of naive St. Croix and Suffolk PBMC by qPCR in reponse to culture with $\boldsymbol{H}$. contortus crude larval or worm antigen. PBMC from primed St. Croix and Suffolk PBMC incubated with $20 \mu \mathrm{l}$ crude larval or worm antigen for 2, 4 or 6 hours and gene expression of II4 (A), II4ra (B), II13 (c), II5 (D), Mrc1 (E), II17 $(F)$ or Ifng $(G)$ was performed by qPCR. Error bars = SEM.

Figure 5
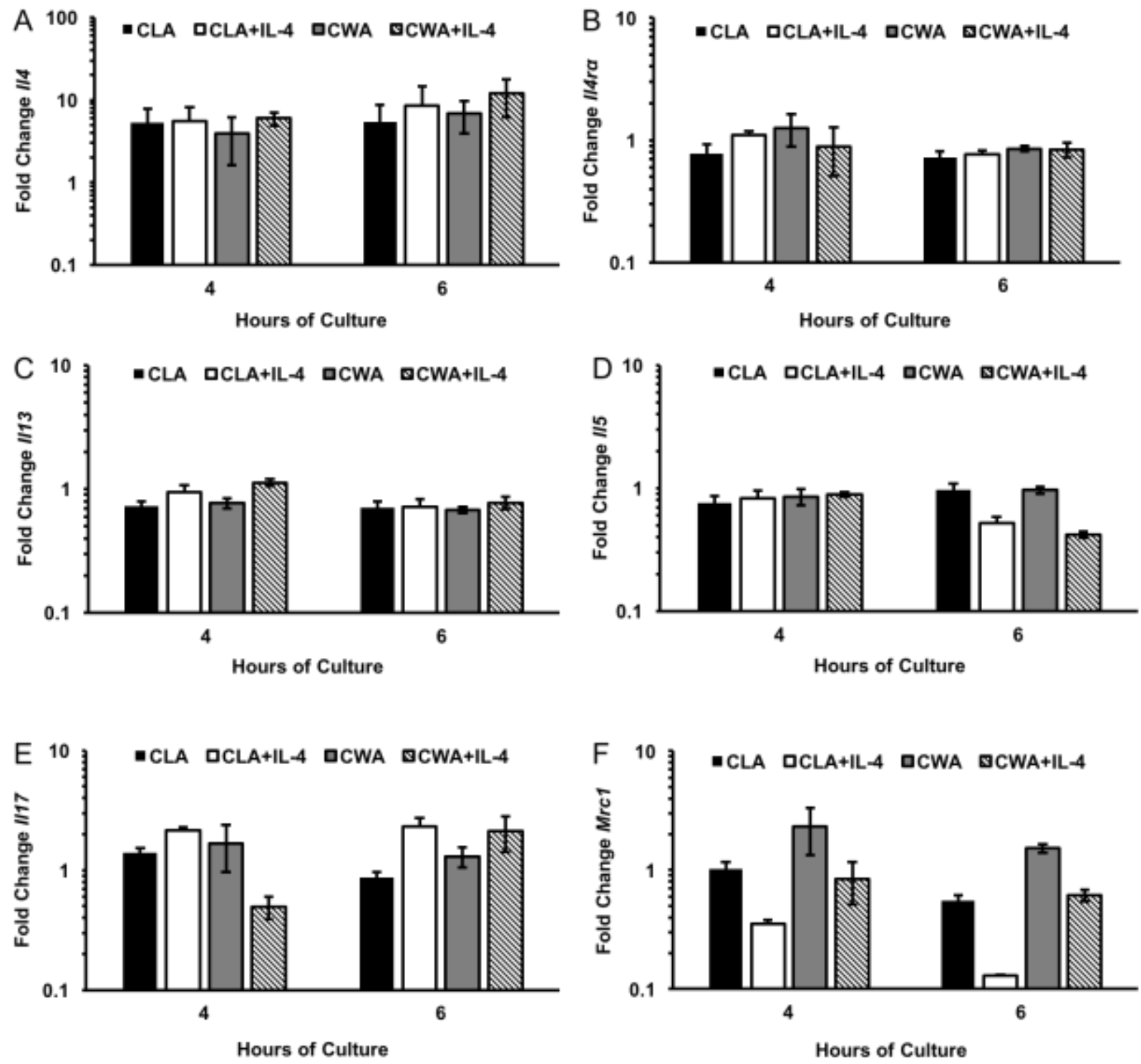
Figure 5: mRNA analysis of primed Suffolk PBMC by qPCR in reponse to culture with $\boldsymbol{H}$. contortus crude larval antigen with or without supplementation with IL-4. PBMC primed Suffolk PBMC incubated with $20 \mu \mathrm{crude}$ larval or worm antigen. +IL4 indicates an addition of supernatant from St. Croix PBMC containing $823.57 \mathrm{pg} / \mathrm{ml} \mathrm{IL-4.}$ PBMC were incubated for 2, 4 or 6 hours and gene expression of II4 (A), II4ra (B), II13 (c), II5 (D), Mrc1 (E), II17 (F) or Ifng $(\mathrm{G})$ was performed by qPCR. Error bars = SEM. 
Figure 6
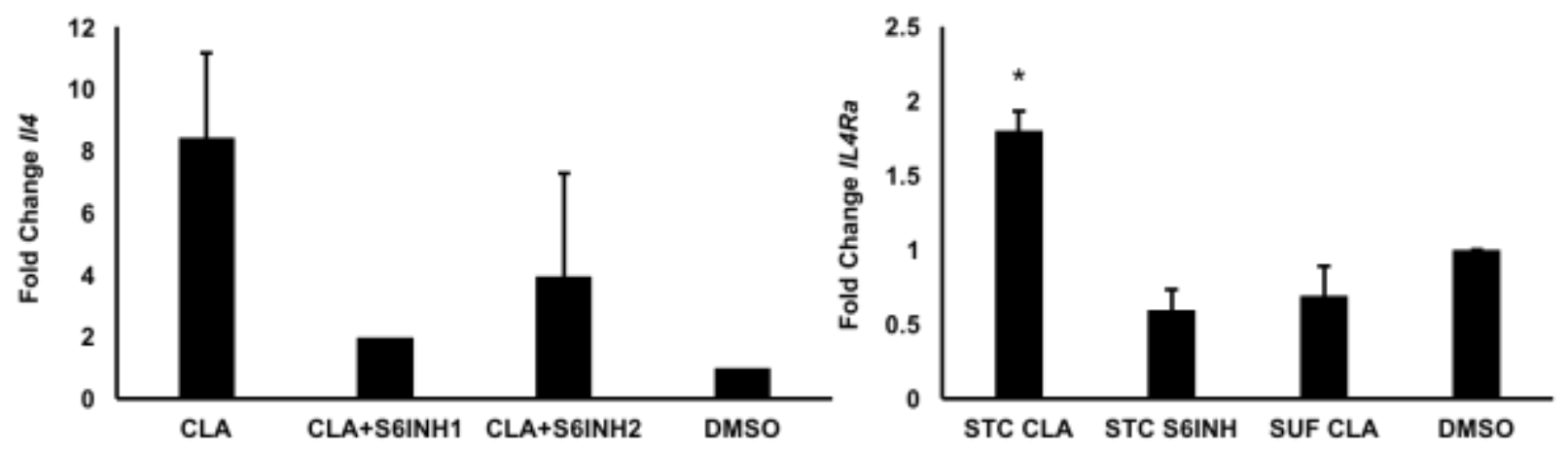

Figure 6: STAT6 inhibition of primed St. Croix PBMC. Primed St Croix PBMC were cultured for 6 hours with $H$. contortus crude larval antigen with or without STAT6 pharmacological inhibitor. STAT6INH1 $=100 \mathrm{~nm}$ inhibitor; STAT6INH2 $=10 \mathrm{~nm}$ inhibitor. mRNA of $\| 4$ and II4ra was analyzed by qPCR. 


\title{
Chapter 3: RNA-Sequencing of PBMC derived from parasite resistant and susceptible sheep reveal differential gene expression after exposure to $H$. contortus antigen
}

\begin{abstract}
Mechanisms of immune activation in immune effector cells during $H$. contortus infection in sheep are currently unknown. Microarray experiments have been performed on tissues of $H$. contortus infected sheep of various parasite resistance during early and late times points, but not in immune effector cells. The purpose of this study was to compare gene activation in peripheral blood mononuclear cells in parasite susceptible and resistant sheep in response to $H$. contortus larval antigen (CLA) at an early time point. PBMC were cultured for 6 hours with CLA and RNA-Sequencing was performed. St. Croix PBMC upregulated 499 unique genes in response to CLA while Suffolk PBMC upregulated 130 unique genes and 25 genes were shared between the two breeds. St. Croix PBMC had increased expression of genes associated with immune function, signal transduction, response to stress and others. In addition, while mechanisms of innate recognition of $H$. contortus is unknown, multiple pattern recognition receptors were found to be upregulated in St Croix PBMC cultured with CLA and none were found to be upregulated in Suffolk PBMC. These patterns of immune gene activation may comtribute to St. Croix's ability to resist $H$. contortus infection.
\end{abstract}

\section{Introduction}

Understanding mechanisms behind parasite resistance in sheep requires understanding immune activation in effector cells. Differences in immune related genes have already been identified in tissues of parasite resistant St. Croix and susceptible 
Suffolk sheep during Haemonchus contortus infection. St. Croix sheep exhibit increases in Th2 related genes in abomasal tissue during early $H$. contortus infection, which may contribute to their enhanced ability to resist $H$. contortus infection. Individual genes have been tested by qPCR in tissue during active $H$. contortus infection wherein St. Croix sheep were found to have detectable IL-4 gene expression as early as three days after infection (Jacobs et al., 2016) while Suffolk sheep do not have detectable IL-4 gene expression until 10 days after infection.

Lymph node cDNA transcripts of $H$. contortus resistant Caribbean hair sheep cross (St. Croix and Barbados Blackbelly) and a susceptible wool composite (Dorset, Rambouillet and Finnsheep mix) were compared using a bovine microarray at 3 and 27 days after $H$. contortus infection (MacKinnon et al., 2009). Genes associated with cellular infiltration and tissue repair were found to be upregulated in hair sheep 3 days after infection (MacKinnon et al., 2009). Genes associated with inflammatory cytokines, gut motility and cell proliferation were upregulated in the lymph nodes of hair sheep 27 days after infection (MacKinnon et al., 2009).

Canaria Hair Breed (CHB) is a $\mathrm{H}$. contortus resistant breed originating from the Canary Islands (Gonzalez et al., 2008). Comparative RNA-Sequencing (RNA-Seq) was performed on abomasal mucosa of resistant CHB sheep and compared to a susceptible breed, Canaria Sheep (CS) 20 days after H. contortus infection. Resistant CHB sheep were found to have 711 significantly upregulated genes after infection with $H$. contortus, while CS sheep had 50 (Guo et al., 2016). The authors concluded CHB resistant sheep induced inflammatory responses faster as well as had increased complement activation, increased cell proliferation, genes associated with tissue repair and immune activation 
directed toward loss of parasite fecundity; all which contribute to $H$. contortus resistance (Guo et al., 2016).

In these studies, we aim to analyze immune activation of peripheral blood mononuclear cells derived from primed parasite resistant St. Croix sheep and susceptible Suffolk sheep using RNA-Sequencing technology. Early immune events have proven to be paramount in parasite expulsion in both murine (Behnke et al., 2003) and ovine (Balic et al., 2000) models. Therefore, we have chosen to analyze gene expression in PBMC after 6 hours of culture with $H$. contortus crude larval antigen.

\section{Materials and Methods}

\section{Animals}

Three adult St. Croix and three adult Suffolk sheep were maintained at the WVU Veterinary Sciences farm on a raised, expanded metal floor barn. Each sheep was born in the elevated floor barn and never grazed on pasture. Six weeks after weaning, each sheep was given an experimental oral inoculation of 10,000 stage $3 \mathrm{H}$. contortus larvae (L3). Each animal was experimentally infected at least three times, however during the time of experimental blood collection, no animals were shedding $H$. contortus eggs in the feces.

\section{Haemonchus contortus larval culture}

Larvae were obtained by fecal culture followed by the Baerrman Technique (Zajac and Conboy. 2012). Feces containing $H$. contortus eggs were collected from chronically infected adult sheep housed in the elevated floor barn. Feces were mixed with sterile peat moss and activated charcoal and allowed to incubate for one week to allow eggs to develop to $L_{3}$ larvae. Larvae were then collected by the Baermann Technique and diluted 
to $1,000 \mathrm{H}$. contortus larvae per $\mathrm{ml}$ in PBS $(\mathrm{pH} 7.4)$. Each lamb was given an oral inoculum of $10 \mathrm{ml}$ of diluted $H$. contortus larvae.

\section{Antigen Preparation}

A one $\mathrm{mL}$ centrifuged pellet of $\mathrm{L}_{3} H$. contortus larvae was homogenized on ice using a tissue homogenizer. Larval lysate was centrifuged at $15,000 \times g$ at $4^{\circ} \mathrm{C}$ for $1 \mathrm{hr}$. Supernatant was removed and sterile filtered through a $0.22 \mu \mathrm{m}$ syringe filter. Sterilfiltered supernatant protein concentration was determined using micro-BCA assay (Pierce, Rockford, IL). After protein quantification, protease inhibitor cocktail (Sigma Aldrich, St. Louis, MO) was added at a rate of $1 \mu \mathrm{l}$ cocktail per $\mu \mathrm{g}$ of protein. Crude worm antigen (CWA) was prepared as described in Bowdridge et al., (2013). Lysate centrifuged at $15,000 \times g$ at $4^{\circ} \mathrm{C}$ for $1 \mathrm{hr}$. Supernatant was removed and sterile filtered through $0.22 \mu \mathrm{m}$ syringe filter. Sterile-filtered supernatant protein concentration was determined using micro-BCA assay. After protein quantification, protease inhibitor cocktail (Sigma Aldrich, St. Louis, MO) was added at a rate of $1 \mu \mathrm{l}$ of cocktail per $\mu \mathrm{g}$ of protein. Crude larval and worm antigen were aliquoted into $1.5 \mathrm{ml}$ microcentifuge tubes and stored at $-80^{\circ} \mathrm{C}$ until further use.

\section{Peripheral blood mononuclear cell separation}

Whole blood was collected by jugular venipuncture into EDTA treated vacutainer tube. Whole blood was centrifuged at $700 \times g$ for 20 minutes at RT with a brake of 6 to separate white blood cells. Buffy coat was removed by pipette and mixed with $1 \mathrm{~mL}$ sterile PBS (Corning, Manassas, VA). Red blood cells were removed with $3 \mathrm{~mL}$ ACK lysis buffer (Lonza, Alpharetta, GA) and re-suspended with sterile PBS. The solution was centrifuged at $112 \times g$ for 5 minutes at RT to pellet WBC. Cells were suspended in $3 \mathrm{~mL}$ sterile PBS 
and layered over $5 \mathrm{~mL}$ of lymphocyte separation media (Corning, Manassas, VA) and centrifuged at $400 \times g$ for 20 mins with a brake of 1 to separate peripheral blood mononuclear cells. PBMC were removed from the transition layer by pipette and resuspended in sterile PBS. Cells were verified to be $>99 \%$ PBMC by Wright stain (Camco, Ft. Lauderdale, FL) and quantified using a TC20 automated cell counter (BioRad, Hercules, CA).

\section{In vitro cell culture}

Peripheral blood mononuclear cells were diluted to $5 \times 10^{6}$ in complete media consisting of RPMI 1640 (GE Healthcare, Marlborough, MA) with $0.1 \%$ FBS (Corning, Manassas, VA) and penicillin/streptomycin/neomysin antibiotic mixture (Fisher Scientific, Waltham, MA). Cells were added to a 96 well round bottom cell culture plate (BD Biosciences, San Jose, CA) at a concentration of 300,000 cells / well. Twelve wells were used per animal per treatment (CLA, CWA) with cells in complete media (CM) as a control. Cells were incubated for indicated times at $37 \mathrm{C}$ and $5 \% \mathrm{CO}_{2}$. Cells and supernatant were removed after incubation. Cells were immediately processed for RNA isolation and supernatant was stored at $-80 \mathrm{C}$ for ELISA.

\section{RNA Isolation}

RNA was isolated using the illustra RNAspin kit (GE Healthcare, Marlborough, MA). All cells from each animal and treatment (12 wells) were pooled together for RNA extraction. RNA quality was assessed using Take3 microvolume plate (BioTek, Winooski, VT) and samples with a $260: 280$ ratio equal to or greater than 1.8 were accepted and diluted in $13 \mu \mathrm{L}$ of DEPC-treated water to a total concentration of $1.8 \mu \mathrm{g}$. 


\section{RNA-Sequencing Data Analysis}

RNA samples were submitted to the WVU Genomics Core of RNA-Sequencing for cDNA library build. FASTQ (raw sequence reads) were checked for quality control using FastQC and assigned a Phred Quality Score. Good quality reads were then aligned against the ovine reference genome Oar_v3.1 using STAR and unique reads were quantified. Data were normalized and statistical analyses were performed using DESeq2 (negative binomial distribution, outlier detection and correction). The Benjamini-Hochberg procedure was performed to obtain adjusted $P$ value with an padj (Benjamini-Hochberg adjusted $P$ value) significance cutoff of 0.05 .

\section{Results}

\section{CLA treatment changes genetic profile of PBMC in St. Croix and Suffolk sheep}

Treatment with crude larval antigen shifted the gene profile expressed by both St. Croix and Suffolk PBMC as can be viewed in Principal Component Analysis (PCA) clustering of treatment groups (Figure 1A). CLA treated samples can be seen shifted to the left while complete media controls cluster on the right. St. Croix and Suffolk CM samples can also be seen clustering together separately from one another, indicating dissimilarity from each other (Figure 1A). Heat mapping of $\mathrm{CM}$ genes indicates dissimilarity between untreated primed St. Croix and Suffolk PBMC seen in green to white while similarities are shown as dark blue (Figure 1B). Similarly, CLA treatment results in distinctly separate clustering in St. Croix and Suffolk PBMC while greater variance is observed between St. Croix samples, which are, as a whole, distinctly different than Suffolk samples, which are less varied (Figure 1C). Variance of gene distribution within St. Croix PBMC and between CLA treated St. Croix and Suffolk can be seen upon heat 
mapping (Figure 1D) wherein St. Croix genes are both dissimilar to each other and to Suffolk genes. Suffolk genes display less variance when compared to each other (Figure 1D).

St. Croix PBMC upregulate more genes in response to $\mathrm{H}$. contortus larval antigen culture

St. Croix PBMC upregulated 499 genes in response to culture with $H$. contortus larval antigen, while Suffolk PBMC upregulated 130 genes and 25 genes were upregulated by PBMC from both breeds (Figure 2). Generic Gene Ontology (GO) mapping indicates PBMC from St. Croix sheep activate more genes than PBMC from Suffolk in the categories of signal transduction (110 vs. 27 ), response to stress (80 vs. 17) and immune system processes (78 vs. 19) (Table 1, Figure 3).

St. Croix PBMC had upregulate of 50 genes associated with inflammation compared to 3 upregulated genes in Suffolk PBMC. NLRP3 was one of the most highly upregulated genes in St. Croix PBMC $(P=7.418 \mathrm{E}-05)$, which is associated with inflammation. St. Croix PBMC also had upregulated IL18R1 $(P=0.017)$, IL18RAP $(P=$ 0.011), IL1A $(P=9.625 \mathrm{E}-05)$, IL1B $(P=0.0004)$, IL1RAP $(P=5.120 \mathrm{E}-05)$, IL6 $(P=0.044)$, NFKB1 $(P=8.735 \mathrm{E}-05), \operatorname{NFKB} 2(P=0.0009)$, IFNGR1 $(P=0.027)$ and IFNGR2 $(P=$ $0.013)$.

Interestingly, 2 of the 10 most upregulated genes in Suffolk PBMC were CD4, costimulatory molecule CD28, T cell receptor alpha constant (TRAC) and lymphoid enhancer-binding factor-1 (LEF1); all associated with the T cell receptor (TCR) (Table 2). However, Suffolk PBMC also upregulate B and T Lymphocyte Attenuator (BTLA, $P=$ 0.037). St. Croix PBMC have upregulated IL36A and PTX3, which are associated with 
primary inflammation (Table 3). St. Croix PBMC also have highly upregulated VEGFA and HBEGF, which are associated with wound healing (Table 3).

St. Croix PBMC upregulated Neutrophil Cytosolic Factors (NCF) NCF2 $(P=0.011)$ and NCF4 $(P=0.014)$ as well as tyrosine phosphokinase HCK $(P=0.0005)$ which are all associated with neutrophil activation. Parasite infections elicit Th2 profiles which are associated with alternatively activated macrophages and would healing profiles. St. Croix PBMC had upregulated ARG2 $(P=0.0005)$, which is a marker of alternatively activated macrophages as well as Matrix Metalloproteinase Proteins (MMP) MMP1 $(P=0.0005)$, MMP2 $(P=0.01), \operatorname{MMP} 3(P=0.014)$ and MMP13 $(P=1.194 \mathrm{E}-06)$, which are associated with wound healing. No matrix metalloproteinases or genes associated with alternatively activated macrophages were found to be upregulated in Suffolk PBMC.

\section{St. Croix PBMC Upregulate Pattern Recognition Receptors}

St. Croix PBMC cultured with $H$. contortus crude larval antigen expressed highly upregulated Toll-Like Receptor 4 (TLR4, $P=8.76 \mathrm{E}-07)$, TLR2 $(P=0.007)$ and TLR6 $(P$ $=0.008$, Table 4). No Toll-Like receptors were found to be upregulated in Suffolk PBMC. In addition, St. Croix PBMC had upregulated C-Type Lectin Receptors (CLEC) CLEC4D $(P=0.0001), \operatorname{CLEC1A}(P=0.004), \operatorname{CLEC5A}(P=0.007), \operatorname{CLEC4E}(P=0.014)$ and CLEC12A $(P=0.02)$ (Table 4). No such C-type lectin receptors were found expressed in Suffolk PBMC.

\section{Discussion}

Genes associated with $H$. contortus infection have been documented, however immune activation of peripheral blood mononuclear cells. RNA-sequencing revealed differential expression of genes between St. Croix and Suffolk PBMC when cultured with 
$H$. contortus crude larval antigen. Gene profiles of PBMC from both primed St. Croix and Suffolk sheep cultured with CLA were distinctly different from media controls. In addition, St. Croix and Suffolk PBMC cultured with CLA were distinctly different from each other and individual St. Croix samples were more varied compared to one another than individual Suffolk samples.

St. Croix PBMC upregulated 499 genes in response to culture with CLA, while Suffolk PBMC upregulated 130. Similar results were found in vivo by RNA-Seq in the abomasal mucosa of parasite resistant Canaria Hair Breed (CHB) sheep compared to susceptible Canaria Sheep (CS) when infected with H. contortus (Guo et al., 2016). In this experiment, 711 genes were found to be upregulated by $\mathrm{CHB}$ sheep compared to 50 upregulated genes in CS (Guo et al., 2016). Also in agreement with Guo and authors' in vivo findings, resistant St. Croix sheep upregulated more genes associated with inflammation than susceptible sheep.

St. Croix PBMC cultured with CLA had high upregulation of NLRP3. NLRP3 is highly associated with the formation of the inflammasome in macrophages, which is capable of processing activating caspase-1, which in turn cleaves pro-IL-1 $\beta$ and pro-IL18 into active IL-1 $\beta$ and IL-18, respectively (Guo et al., 2015). IL-1 $\beta$ and IL-18 are both highly associated with inflammation (Lamkanfi et al., 2012). In addition to contributing to inflammation, recent studies show NLRP3 is able to translocate to the nucleus and transactivate Th2 profiles genes (Bruchard et al., 2015), though NLRP3's role in $H$. contortus infection is currently unknown. St. Croix PBMC also had upregulated of Maf, which has the ability to transactivate IL-4 (Ho et al., 1998). 
Suffolk PBMC showed upregulation of genes associated with the TCR, which would indicate activation of T cells. However, Suffolk PBMC also expressed highly upregulated, which is an inhibitor of B and T lymphocytes (Villen et al., 1997; Gavrieli et al., 2004). These combatting mechanisms may contribute to parasite susceptibility in Suffolk sheep.

Guo and others found a wound healing genes upregulated in parasite resistant sheep during $H$. contortus infection such as extracellular matrix, fibronectin and multiple collagen genes. Similarly, we found 5 matrix metalloproteinases to be upregulated in St. Croix PBMC in response to CLA. Interestingly, wound healing profiles are typically activated by damage signals (Joao and Jacinto, 2013), however MMP genes were still activated in in vitro culture. Macrophages may be alternatively activated by IL-4 (Varin et al., 2010) and are characterized by Arg2 expression (Troidl et al., 2009), which was found to be highly upregulated in St. Croix PBMC cultured with CLA.

Neutrophil infiltration to the abomasum has been observed to be increased in St. Croix sheep 3 days after infection with $H$. contortus (Bowdridge et al., 2013). In this experiment we found genes associated with the activation, degranulation and chemotaxis to be upregulated in CLA cultured PBMC from St. Croix sheep.

Peptide antigens recognized by memory T cells during $H$. contortus are not known. In addition, mechanisms of innate recognition of $H$. contortus are not known. In this study we found PBMC from primed St. Croix sheep to have upregulation of multiple pattern recognition receptors. TLR2, upregulated in St. Croix PBMC, has been implicated in parasite infection wherein TLR2 deficient mice have more severe symptoms associated with neurocysticercosis secondary to Mesocestoides corti helminth infection (Gundra et 
al., 2011). Similarly, TLR4 mediation of MyD88 signaling confers protection during Leishmania donovani infection (Paul et al., 2014). C-type lectin receptors have not yet been indicated in parasite infections, but are capable of affecting TLR signaling and regulating adaptive immune responses (Teunis et al., 2009).

The data collected in this experiment reflects published in vivo cellular and gene expression data as well as bears similarity to RNA-Seq data conducted in tissues of parasite resistant and susceptible sheep. Here we described a significant difference in the number of genes upregulated between PBMC from parasite resistant St. Croix and susceptible Suffolk sheep. St. Croix PBMC upregulation of increased numbers of inflammatory associated genes, pattern receptor recognition receptors and neutrophil activation in effector cells after only 6 hours of antigen culture may contribute to the ability of St. Croix sheep to resist $H$. contortus infection. 


\section{Literature Cited}

Balic, A., V. Bowles, and E. Meeusen. 2000. Cellular profiles in the abomasal mucosa and lymph node during primary infection with Haemonchus contortus in sheep. Vet. Immunol. Immunopath. 75: 109-120.

Behnke, JM., Lowe, A., Clifford S., and D Wakelin. 2003. Cellular and serological responses in resistant and susceptible mice exposed to repeated infection with Heligmosomoides polygyrus bakeri. Parasit. Immunol. 25(6): 333-340.

Bruchard, M., Rebe, C., Derangere, V., Togbe, D., Ryffel, B., Boidot, R., Humblin, E., Hamman, A., Chalmin, F., Berger, H., Chevriaux, A., Limagne, E., Apetoh, L., Vegran, F., and F. Ghiringhelli. 2015. The receptor NLRP3 is a transcriptional regulator of TH2 differentiation. Nat Immunol. 16(8): 859-870.

Bowdridge, S., Mackinnon K., McCann J., Zajac, A., and D. Notter. 2013. Hair-type sheep generate an accelerated and longer-lived humoral immune response to Haemonchus contortus infection. Vet. Parasitol. 196: 172-178.

Bowdridge, SA., Zajac AM., and DR Notter. 2013. St. Croix sheep produce a rapid and greater cellular immune response contributing to reduced establishment of Haemonchus contortus. Vet Parasitol. 208(3-4): 204-210.

Burke, JM., and JE Miller. 2002. Relative resistance of Dorper crossbred ewes to gastrointestinal nematode infection compared with St. Croix and Katahdin ewes in the southeastern United States. Vet Parasitol. 109(3-4): 265-275.

Gamble HR and AM Zajac. 1992. Resistance of St. Croix lambs to Haemonchus contortus in experimentally and naturally acquired infections. Vet Parasitol. 41(34): $211-225$.

Gavrieli, M., Watanabe, N., Loftin, SK., Murphy, TL., and KM Murphy. 2003. Characterization of phosphotyrosine binding motifs in the cytoplasmic domain and $B$ and $T$ lymphocyte attenuator required for association with protein tyrosine phosphatases SHP-1 and SHP-2. Biochem Biophys Res Commun. 312(4): 12361243.

Gonzalez, JF., Hernandez, A., Molina, JM., Fernandez, A., Raadsma, HW., Meeusen, EN., and D Piedrafita. 2008. Comparative experimental Haemonchus contortus infection of two sheep breeds native to the Canary Islands. Vet Parasitol. 153(34): 374-378.

Gundra, UM., Mishra, BB., Wong, K., and JM Teale. 2011. Increased disease severity of parasite-induced TLR2-/- mice is correlated with decreased central nervous system inflammation and reduced number of cells with alternatively activated 
macrophage phenotypes in a murine model of neurocysticercosis. Infec Immun. 79(7): 2586-2596.

Guo, H., Callaway, JB., and JPY, Ting. 2015. Inflammasomes: mechanism of action, role in disease, and therapeutics. Nat Med. 21(7): 677-687.

Guo, Z., Gonzalez, JF, Hernandez, JN, McNielly, TN., Crripio-Moyar, Y., Frew, D., Morrison, T., Yu, P., and RW Li. 2016. Possible mechanisms of host resistance to Haemonchus contortus infection in sheep breeds native to the Canary Islands. Sci Rep. 6:26200.

Ho, IC, Lo, D., and LH Glimcher. 1998. C-Maf promotes T helper cell type 2 (Th2) and attenuates Th1 differentiation by both interleukin-4-dependent and -independent mechanisms. J Exp Med. 188(10): 1859-1866.

Jacobs, JR., Sommers, KN., Zajac, AM., Notter, DR., and SA Bowdridge. 2016. Early IL-4 gene expression in abomasum is associated with resistance to Haemonchus contortus in hair and wool sheep breeds. Parasit Immunol. 38(6): 333-339.

Joao, V. and Antonio Jacinto. 2013. The role of transcription-independent damage signals in the initiation of epithelial wound healing. Nat Rev Molec Cell Bio. 14: 249-262.

Katakura, T., Miyazaki, M., Kobayashi, M., Herndon, DN., and F Suzuki. 2004. CCL17 and IL-10 as effectors that enable alternatively activated macrophages to inhibit the generation of classically activated macrophages. J Immunol. 172(3): 14071413.

Krummel, MF and JP Allison. 1994. CD28 and CTLA-4 have opposing effects on the response of T cells to stimulation. J Exp Med. 182(2): 459-465.

Lamkanfi, M and VM Dixit. 2012. Inflammasomes and their roles in health and disease. Annu Rev Cell Dev Biol. 28: 137-161.

MacKinnon, K., Bowdridge, SA., Kanevsky-Mullarky, I., Zajac, AM., and DR Notter. 2015. Gene expression profiles of hair and wool sheep reveal importance of Th2 immune mechanisms for increased resistance to Haemonchus contortus. J Anim Sci. 93(5): 2074-2082.

MacKinnon, K., Zajac, A., Kooyman, F., and D Notter. 2010. Differences in immune parameters are associated with resistance to Haemonchus contortus in Caribbean hair sheep. Parasit Immunol. 32: 484-493.

Mosser, DM., and JP Edwards. 2008. Exploring the full spectrum of macrophage activation. Nat Rev Immunol. 8(12): 958-969. 
Paul, J., Naskar, K., Chowdhury, S., Alam, MN., Chakraborti, T., and T. De. 2014. TLR4-mediated activation of MyD88 signaling induces protective immune response and IL-10 down-regulation in Leishmania donovani infection. Indian J Biochem Biophys. 51(6): 531-541.

Teunis, B., Geijtenbeek, H., and SI Gringhuis. 2009. Signalling through C-type lecting receptors: shaping immune responses. Nat Rev Immunol. 9: 465-479.

Troidl, C., Mollmann, H., Nef, H., Masseli, F., Voss, S., Szardien, S., Willmer, M., Rolf, A., Rixe, J., Troidle, K., Hamm, C., and A. Elsasser. 2009. Classically and alternatively activated macrophages contribute to tissue remodeling after myocardial infarction. J Cell Mol Med. 13(9b): 3485-3496.

Varin, A., Mukhopadhyay, S., Herbein, G., and S. Gordon. 2010. Alternative activation of macrophages by IL-4 impairs phagocytosis of pathogens but potentiates microbial-induced signaling and cytokine secretion. Blood. 115(2): 353-362.

Vilen, BJ., Famigletti, SJ., Carbone, AM., Kay, BK and JC Cambier. 1997. B cell antigen receptor desensitization: disruption of receptor coupling to tyrosine kinase activation. J Immunol. 59(1): 231-243. 


\section{Figures}

\section{Figure 1}

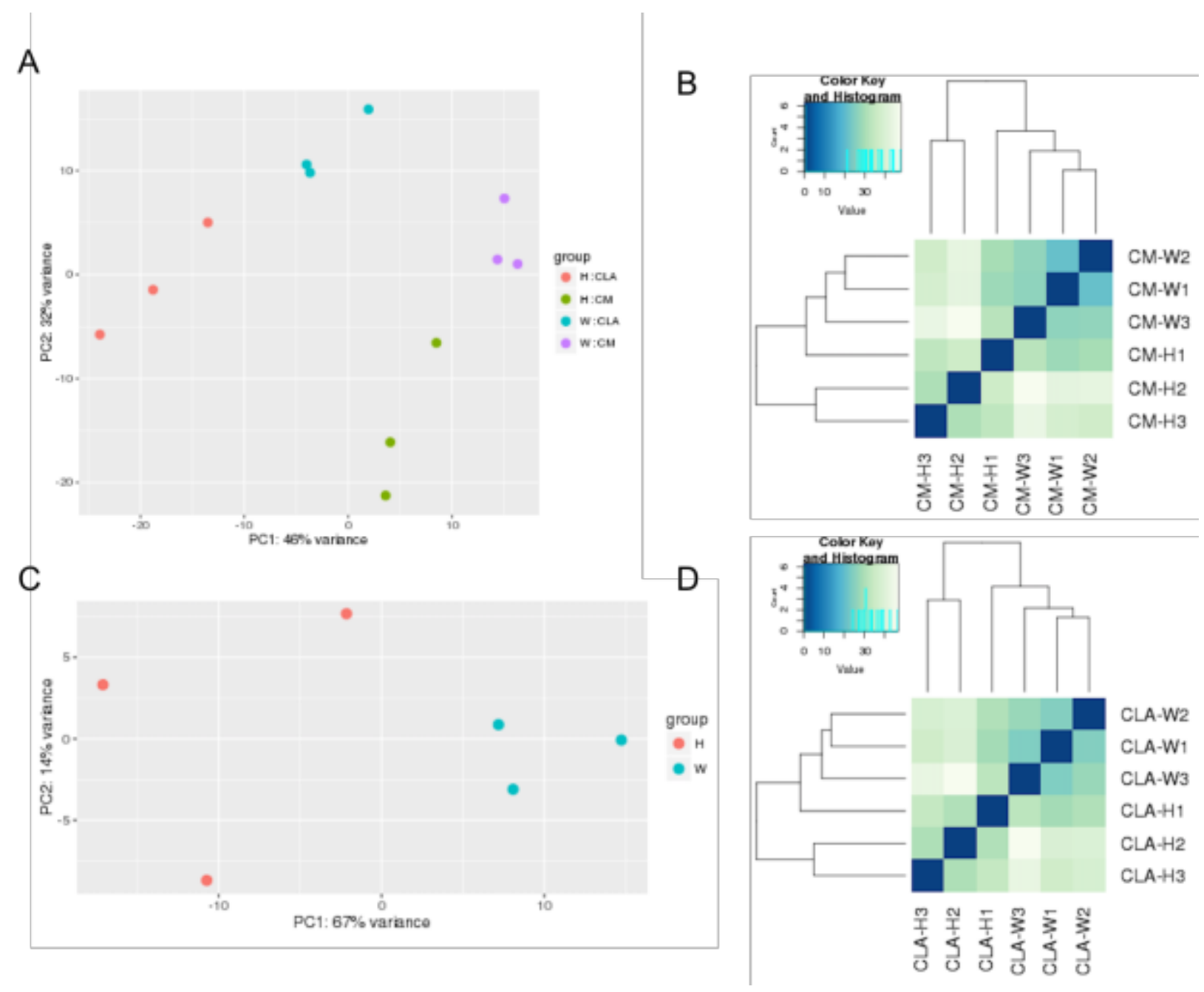

Figure 1: Differential gene profile in St. Croix and Suffolk PBMC after treatment with $\mathrm{H}$. contortus larval antigen. A. Principal component analysis (PCA) comparison of crude larval antigen (CLA) treated St. Croix ( $\mathrm{H}=$ Hair) PBMC (orange), St. Croix $(\mathrm{H})$ complete media control (CM) PBMC (green), CLA treated Suffolk (W = Wool) PBMC (blue), and CM control Suffolk (W) PBMC (purple). B. Heat map comparison of St. Croix $(\mathrm{H})$ and Suffolk $(W)$ untreated PBMC. C. PCA comparison of CLA treated St. Croix (H) PBMC (orange) and CLA treated Suffolk (W) PBMC (blue). D. Heat map comparison of CLA treated St Croix $(\mathrm{H})$ and Suffolk $(\mathrm{W})$ PBMC. 


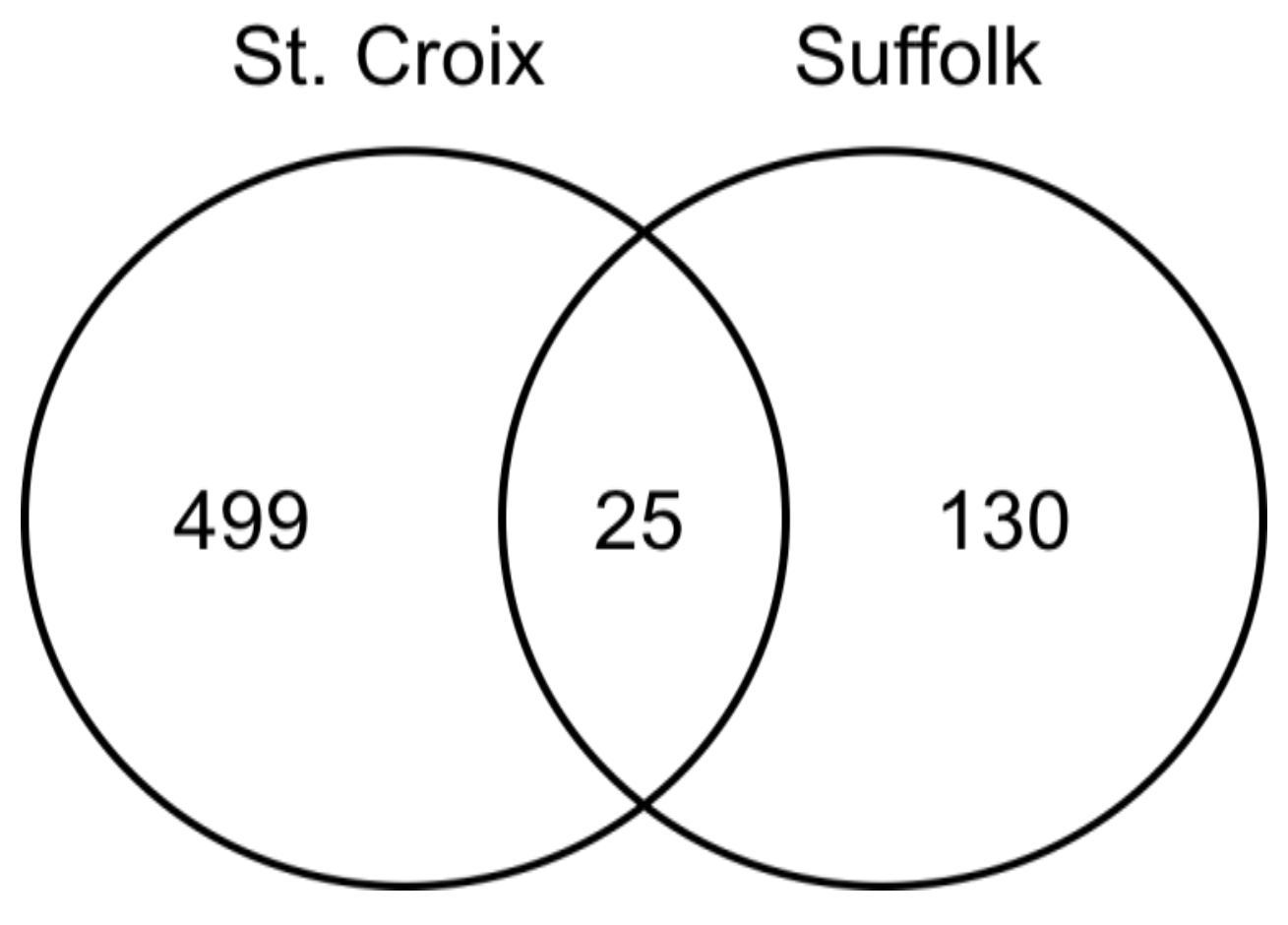

Figure 2: Comparison of gene upregulation in St. Croix and Suffolk PBMC resulting from CLA stimulation. Venn diagram illustrates St. Croix upregulate 499 unique genes in response to 6 hours of culture with CLA, Suffolk PBMC upregulate 130 unique genes and 25 genes were upregulated by both St. Croix and Suffolk PBMC. 


\section{Table 1}

Table 1: Ontological list of genes upregulated by breed type

\begin{tabular}{lcc}
\hline \hline & \multicolumn{2}{c}{ Breed } \\
\cline { 2 - 3 } GO Term & St. Croix & Suffolk \\
\hline Signal Transduction & 110 & 27 \\
Anatomical Structure Development & 94 & 2 \\
Response to Stress & 80 & 17 \\
Immune Sysytem Process & 78 & 19 \\
Biosynthetic Process & 77 & 15 \\
Cell Differentiation & 65 & 12 \\
Metabolic Process & 65 & 17 \\
Protein Modification Process & 64 & 0 \\
Transport & 61 & 8 \\
Cell Death & 45 & 11 \\
Locomotion & 42 & 5 \\
Cell Proliferation & 41 & 10 \\
Cell Motility & 37 & 4 \\
Cell Adhesion & 30 & 7 \\
Cell-Cell Signaling & 21 & 3 \\
\hline \hline
\end{tabular}


Figure 3
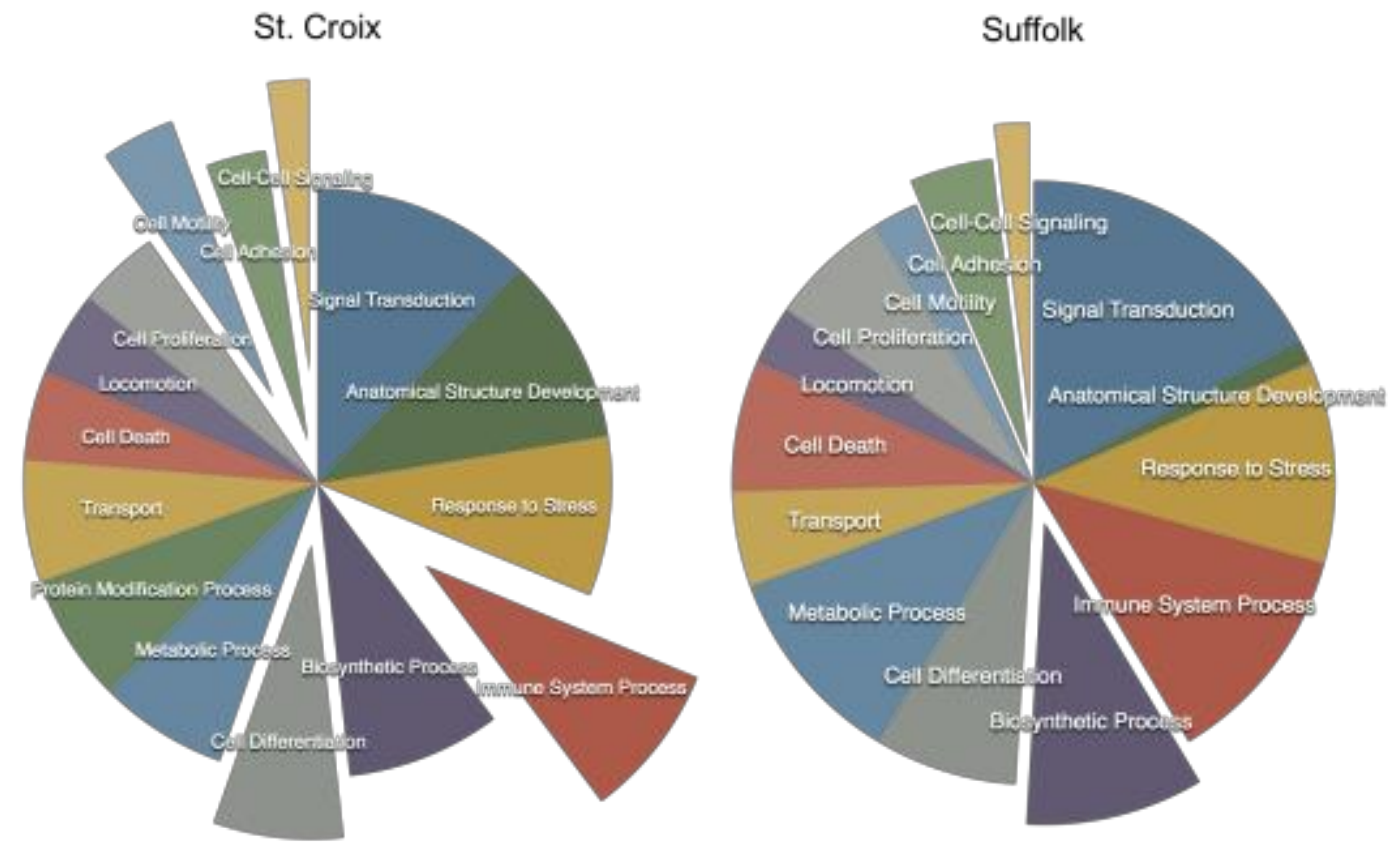

Figure 3: St. Croix PBMC upregulate more genes associated with signal transduction and immune processes. St. Croix PBMC upregulate more genes associated with a variety of biological processes than Suffolk PBMC after 6 hours of culture with CLA. 


\section{Table 2}

Table 2: 10 Most Highly Upregulated Genes in SUF PBMC

\begin{tabular}{lccc} 
Gene & Base Mean & Log2 FC & AdjP value \\
\hline CD20 & 288.149 & 2.498 & $6.44 \mathrm{E}-21$ \\
TRAC & 1496.413 & 1.364 & $4.48 \mathrm{E}-15$ \\
CD4 & 738.179 & 1.469 & $2.82 \mathrm{E}-10$ \\
LEF1 & 619.634 & 1.122 & $1.48 \mathrm{E}-09$ \\
ADD3 & 1335.62 & 1.205 & $3.87 \mathrm{E}-09$ \\
ACTN1 & 419.486 & 1.115 & $5.13 \mathrm{E}-08$ \\
CD28 & 166.454 & 1.241 & $8.57 \mathrm{E}-08$ \\
DGKA & 759.657 & 1.034 & $1.05 \mathrm{E}-07$ \\
TSHZ2 & 51.306 & 1.877 & $2.03 \mathrm{E}-07$ \\
PDK1 & 286.701 & 1.368 & $2.99 \mathrm{E}-07$ \\
\hline
\end{tabular}




\section{Table 3}

Table 3: 10 Most Highly Upregulated Genes in STC PBMC

\begin{tabular}{lccc} 
Gene & Base Mean & Log2 FC & Adj $\boldsymbol{P}$ value \\
\hline PTX3 & 1512.951 & -2.501 & $7.79 \mathrm{E}-14$ \\
RGS1 & 1228.35 & -1.718 & $5.60 \mathrm{E}-14$ \\
RGS16 & 169.947 & -2.145 & $1.92 \mathrm{E}-12$ \\
PTGS2 & 109.238 & -2.232 & $5.33 \mathrm{E}-12$ \\
IL36A & 82.328 & -1.899 & $2.82 \mathrm{E}-10$ \\
SLC1A5 & 728.542 & -1.659 & $1.12 \mathrm{E}-09$ \\
VEGFA & 439.69 & -2.323 & $3.67 \mathrm{E}-09$ \\
CD82 & 605.631 & -1.174 & $3.67 \mathrm{E}-09$ \\
HBEGF & 853.944 & -2.024 & $2.01 \mathrm{E}-08$ \\
MYOF & 115.206 & -2.093 & $3.12 \mathrm{E}-08$ \\
\hline
\end{tabular}


Table 4

Table 3: 10 PRR Genes Upregulated in STC PBMC

\begin{tabular}{lccc}
\hline \hline Gene & Base Mean & Log2 FC & AdjPvalue \\
\hline TLR4 & 1218.43 & -2.047 & $8.76 \mathrm{E}-07$ \\
TLR2 & 1015.2 & -1.098 & $7.00 \mathrm{E}-03$ \\
TLR6 & 302.48 & -1.078 & $8.00 \mathrm{E}-03$ \\
CLECL4D & 63.76 & -1.339 & $1.00 \mathrm{E}-04$ \\
CLEC1A & 19.83 & -1.477 & $4.00 \mathrm{E}-03$ \\
CLECL5A & 1573.81 & -1.551 & $7.00 \mathrm{E}-03$ \\
CLEC4E & 19.05 & -1.349 & $1.40 \mathrm{E}-02$ \\
CLEC12A & 119.67 & -1.036 & $2.00 \mathrm{E}-02$ \\
\hline
\end{tabular}


Figure 4

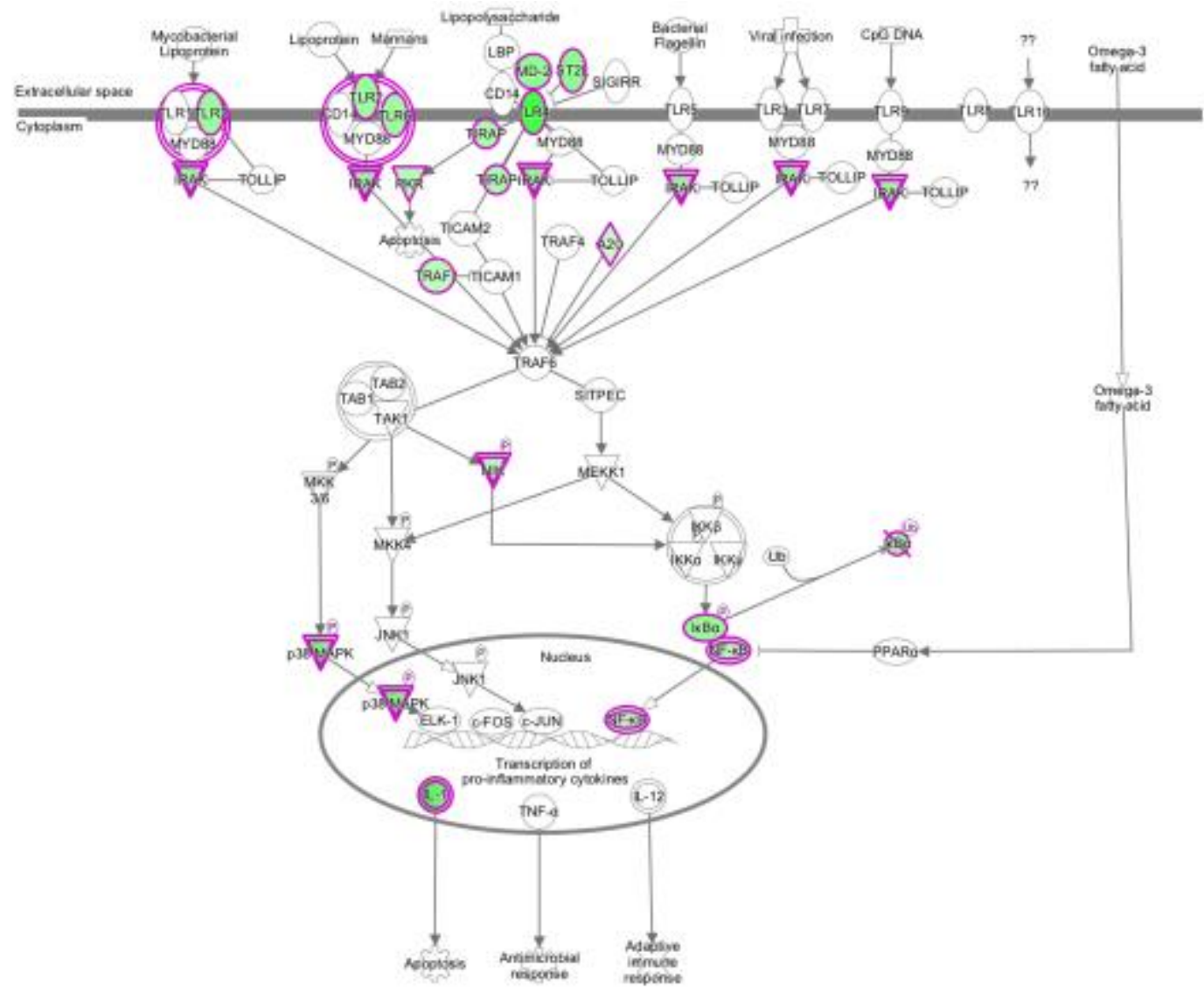

Figure 4: Toll-like receptor pathway activation in St. Croix PBMC. 
Figure 5

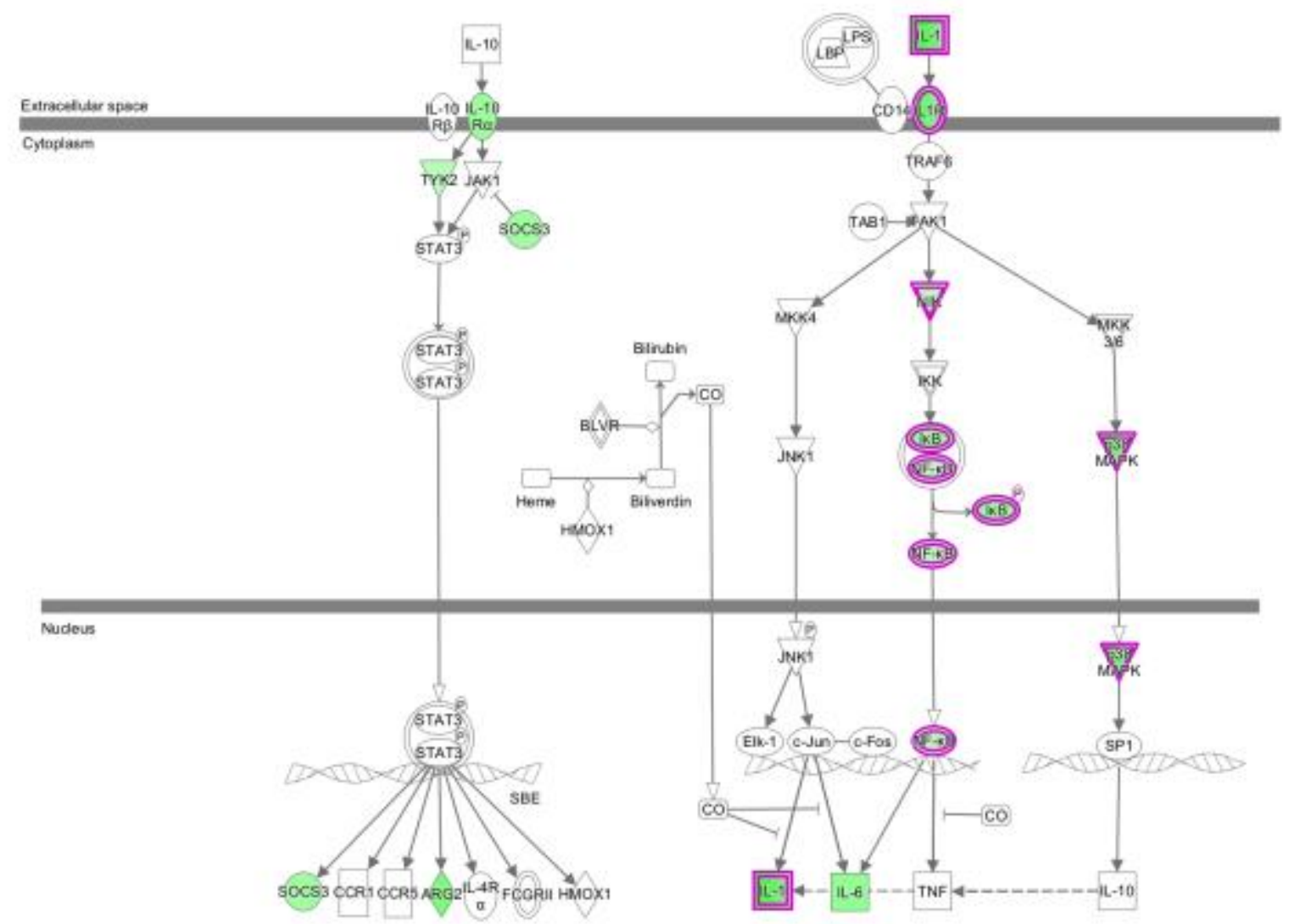

Figure 5: IL-10 pathway activation in St. Croix PBMC. 
Figure 6

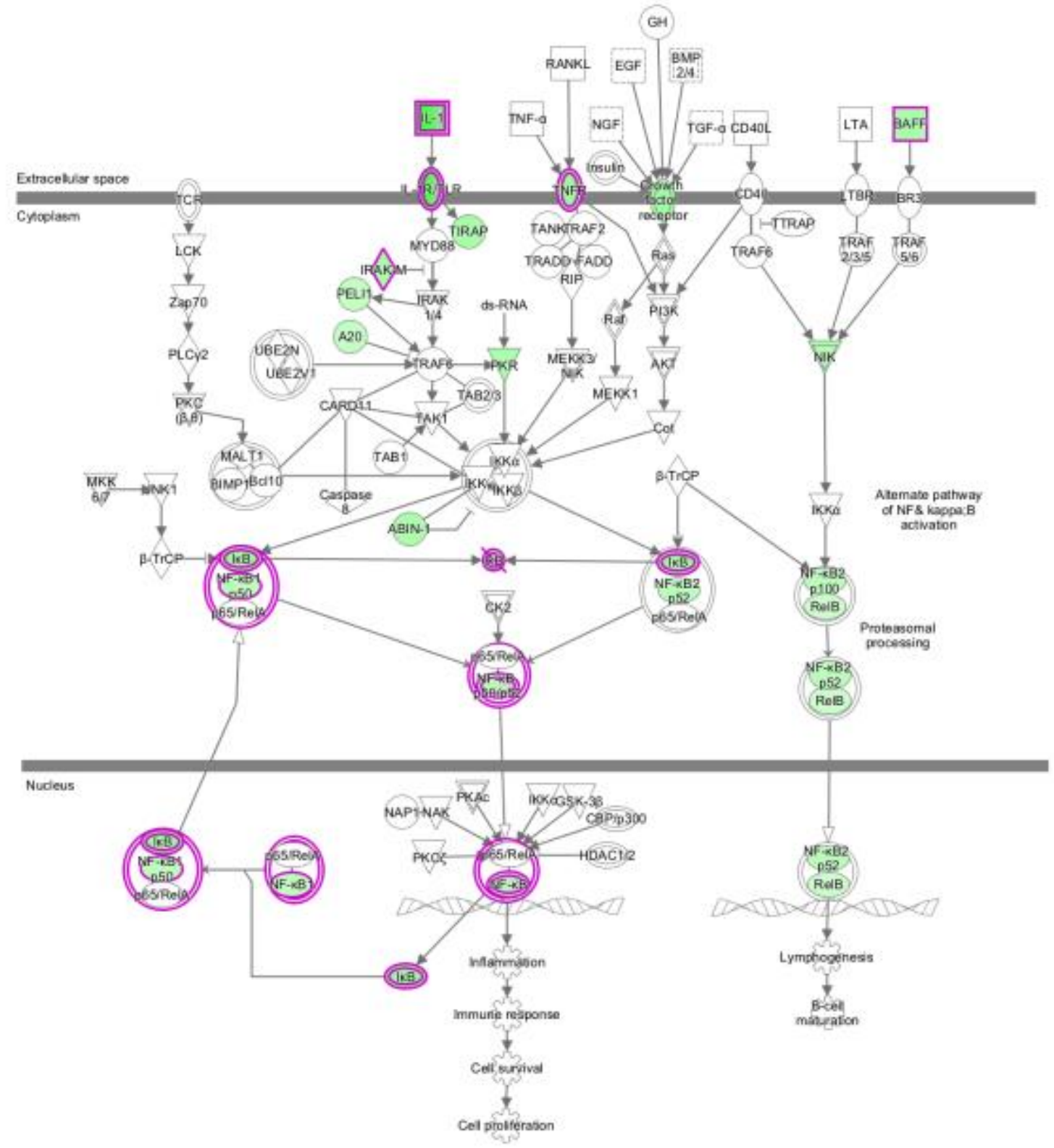

Figure 6: Monocyte function pathway in St. Croix PBMC. 
Figure 7

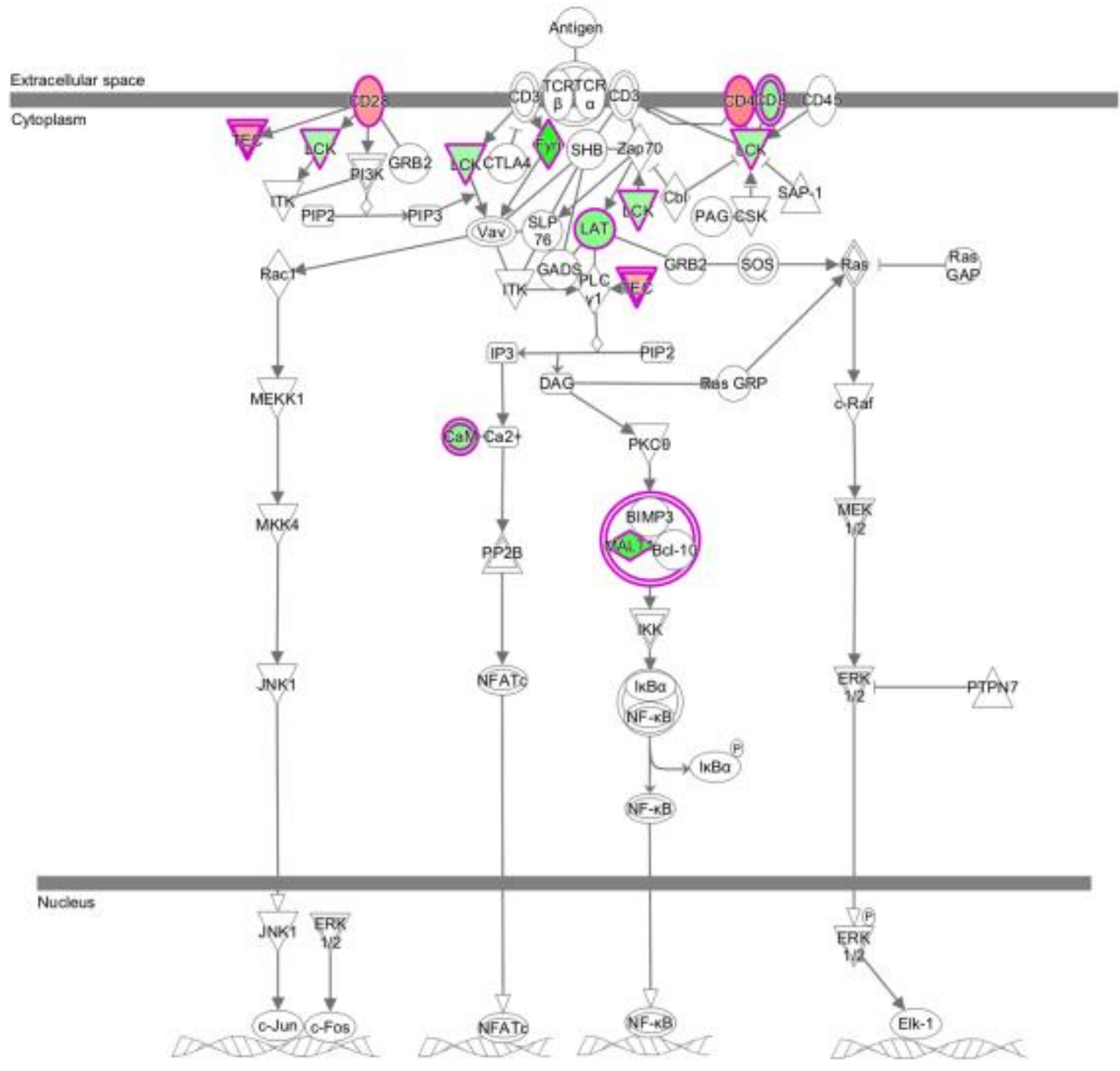

Figure 7: T cell function pathway activation in Suffolk PBMC. 
Figure 8

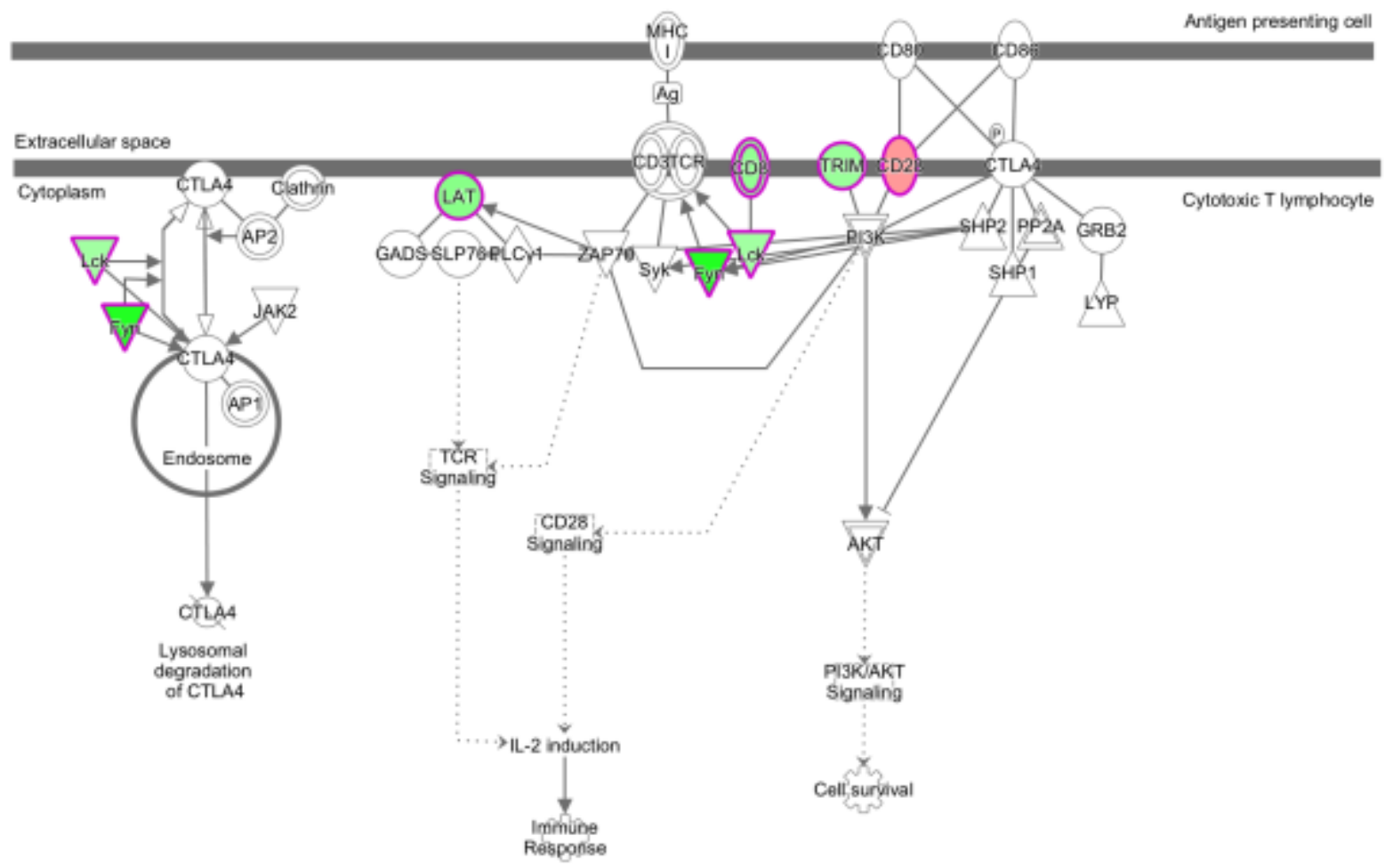

Figure 8: CTLA4 pathway activation in Suffolk PBMC. 


\section{Chapter 4: Discussion}

Haemonchus contortus has a devastating effect on the sheep industry which increases with time. Losses due to $H$. contortus in Australia, a global leader in sheep meat and wool production, has been estimated to be 1 billion in sheep and cattle a decade ago (McLeod, 1995; Sackett and Holmes, 2006). The global cost of $H$. contortus worldwide was estimated to be tens of billions in 2013 (Roeber et al., 2013). While St. Croix are an $H$. contortus breed of sheep, producers are reticent to incorporate the breed as they have undesirable carcass characteristics and lack wool (Burke et al., 2003). Though they are productively undesirable, St. Croix sheep provide an immunological model for $H$. contortus research.

Significantly reduced fecal egg count during $H$. contortus infection has been demonstrated in the literature multiple times since 1985 in naturally and experimentally acquired infections (Courtney et al., 1985; Gamble and Zajac, 1992; Jacobs et al., 2015) as well as lower worm burden upon sacrifice (LaCroux et al., 2006; Bowdridge et al., 2015). Lowered fecal egg count and abomasal worm burden in resistant sheep has been attributed to immune response (Pena et al., 2004) and Lacroux and others found $H$. contortus infection specifically elicits a T helper type 2 (Th2) response in sheep (Lacroux et al., 2006). However, the mechanism of Th2 development in parasite resistant sheep is not known.

In vitro culture of various ovine immune cells is described in the literature. Terefe and others evaluated effects of sheep eosinophils on whole, live third stage $H$. contortus in vitro (Terefe et al., 2007). Wang and others isolated a galectin protein from $H$. contortus and subsequently analyzed its immunomodulatory effects on goat $\mathrm{T}$ cells and 
macrophages (Wang et al., 2014). Extracellular trap production by eosinophils has been evaluated by in vitro culture with H. contortus larvae (Muñoz-Caro et al., 2015). However, evaluation and comparison of immune response by parasite resistant and susceptible peripheral blood mononuclear cells in response to $H$. contortus has not been described in the literature.

Interleukin-4 is the characteristic cytokine associated with priming Th2 responses (Zheng and Flavell, 1997). IL-4 mRNA in abomasal lymph nodes and abomasal fundic mucosa was found to be increased in INRA 401 lambs 3 days after $H$. contortus infection compared to naive lambs or lambs given a single, primary infection (Lacroux et al., 2006). Challenged lambs additionally had fewer $H$. contortus larvae present in the abomasum (Lacroux et al., 2004), indicating the ability to form protective immunity associated with the presence of IL-4 mRNA. Parasite resistant St. Croix sheep are found to have increased circulating IL-4 during $H$. contortus infection when compared to parasite resistant Suffolk sheep (Jacobs et al., 2015) as well as increased IL-4 gene expression in the abomasum during early infection (Jacobs et al., 2016). Suffolk sheep are unable to generate measurable IL-4 mRNA until 10 days of infection with $H$. contortus, at which time they had significantly greater worm burden in the abomasum (Sommers, 2014), which is a 7-day delay compared to St. Croix sheep.

In agreement with these data, we found primed St. Croix PBMC were able to produce more IL-4 protein in response to $H$. contortus larval antigen (CLA, $10 \mu \mathrm{g} / \mathrm{ml}$ ) than Suffolk PBMC after 6 hours of culture. Suffolk PBMC did not produce measurable IL-4 protein until 72 hours of culture; a nearly 3-day delay. Primed Suffolk PBMC were able to generate IL-4 protein at 6 hours in response to larval culture when the amount of 
CLA was doubled, however the protein concentration was nearly $50 \%$ less than St. Croix PBMC. This may indicate that Suffolk effector cells require increased amount of antigen exposure to generate a response to $H$. contortus and would therefore not respond to chronic, low level exposure to $H$. contortus. As early IL-4 production is correlated with lower fecal egg count and larval burden and high level exposure of antigen was still not sufficient to generate IL-4 production in Suffolk PBMC equal to St. Croix response, these data may explain why Suffolk sheep succumb to $H$. contortus infection.

Typically, T cell activation in response to specific antigen occurs in $72-96$ after antigen exposure (McLeod et al., 2010). In these experiments, we found St. Croix PBMC to produce IL-4 protein after 6 hours of culture with $H$. contortus antigen, indicating an alternative cellular source. Innate cells are able to respond to pathogens quickly and monocytes, an innate cell, are found in the PBMC mixture. No literature, as of yet, indicates monocytes / macrophages may be a source of IL-4 protein, however these data indicate the possibility of IL-4 production by these innate cells.

When further testing Th2 activation in St. Croix and Suffolk PBMC, we found a variety of important Th2 genes to be upregulated in St. Croix PBMC at an early time in response to culture with $H$. contortus larval antigen including the IL-4 receptor (IL4Ra), IL-13, IL-5 and mannose receptor, C type 1 (Mrc1). Urban and others found that IL4Ra, IL-13 and STAT6 were required for the expulsion of gastrointestinal nematode Nippostrongylus brasiliensis in mice (Urban et al., 1998). IL-5 is important for the recruitment of eosinophils (Terada et al., 1993), which are associated with parasite infection in mice (Else and Grencis, 1991) and increased eosinophilia in $H$. contortus infection in resistant sheep (Gill, 1998). Mrc1 is a marker of IL-4 dependent alternatively 
activated / wound healing macrophages (Loke et al., 2002), which have been associated with expulsion of parasites (Noel et al., 2004). PBMC from naïve sheep of either breed did not upregulate Th2 profile genes.

Activation of memory T cells by a combination of macrophage induced IL-4 and antigen presence may lead to faster induction of Th2 genes in St. Croix PBMC. As there is a clear difference in IL-4 production between breeds in cell culture supernatants and macrophages are a likely source, Suffolk macrophages may have a deficiency in function. Inability of Suffolk macrophages to recognize $H$. contortus antigen would result in an absence of IL-4 production. RNA-Seq evidence shown here indicates innate pathogen recognition receptors are not upregulated in St. Croix PBMC when cultured with $H$. contortus antigen, which is evidence of inability of innate cells with the PBMC mixture to recognize $H$. contortus antigen.

IL-4 protein was not completely absent in Suffolk cultures, highlighting Suffolk PBMC are capable of producing IL-4. The decreased amount of IL-4 protein in Suffolk PBMC cultures and PRR upregulation compared to St. Croix cultures may indicate a larger requirement for antigen quantity for recognition and activation by Suffolk PBMC. An increased requirement for antigen concentration for immune activation in Suffolk animals could be responsible for the documented delay in response to $H$. contortus by Suffolk animals. If Suffolk are unable to respond until large quantities of parasites, and therefore antigen is present, larvae may be allowed to develop to adults before immune activation occurs. At which point, parasite burden may be too high for susceptible animals to manage. 
Given alternative activation of macrophages is dependent on IL-4, the possibility existed Suffolk PBMC did not generate enough IL-4 to activate these cells. Additionally, we hypothesized IL-4 production from primed Suffolk PBMC was not sufficient to activate any Th2 related genes. Therefore, we supplemented Suffolk PBMC cultured with CLA with supernatant from St. Croix PBMC cultured with CLA, as it had a known amount of IL-4 protein double that of Suffolk. Increased IL-4 in addition to CLA challenge was not sufficient to cause upregulation of Mrc1 or any other Th2 associated genes tested in Suffolk PBMC. These data indicate lack of IL-4 protein availability is not the cause of lack of Th2 response in Suffolk PBMC as St. Croix PBMC were able to upregulate Th2 genes with the same concentration of IL-4.

While PBMC of each breed are able to produce IL-4 in response to CLA, the pathway by which IL-4 is produced may be different in the two breeds. Classically, Th2 activation in the presence of IL-4 is achieved through ligation of the IL-4 receptor, leading to phosphorylation and nuclear translocation of STAT6 and promotion of GATA3 and Th2 profile transcription (Takeda et al., 1996). Based on Th2 activation in St. Croix PBMC in response to $H$. contortus, the classical pathway is presumed, though none of the primers for ovine STAT6 or GATA3 designed and tested by us were successful. However, we were able to observe a consistent downregulation of IL4Ra by Suffolk PBMC. Presumably, in order for IL-4 mediated up-regulation of Th2 genes to occur, the presence of IL4Ra would be required as observed in St. Croix PBMC in response to CLA.

Because Suffolk PBMC were able to produce, but did not upregulate Th2 genes and STAT6 is known to be required for Th2 activation, but not IL-4 production (Kaplan et al., 1999), we evaluated the role of STAT6 in St. Croix PBMC genetic phenotype by 
subsequent expression of IL4Ra. Suffolk PBMC are able to generate IL-4, but show an apparent inability complete IL-4 signaling and lack of IL-4 receptor. We found if STAT6 is inhibited in St. Croix PBMC, expression of IL4Ra is reduced to a similar level observed in Suffolk PBMC after CLA exposure. STAT6 variants have been documented to be expressed in differing breeds of cattle wherein different carcass traits are observed (Rincon et al., 2009). As such, it may be possible for single nucleotide polymorphisms (SNP) to be present in sheep, as well, which could account for the lack of Th2 activation observed in Suffolk PBMC. An inactive or less functional variant of STAT6 in Suffolk sheep may be able to explain their ability to produce IL-4, but fail to further upregulate Th2 genes in the same time frame as St. Croix. These findings create the need for sequencing and comparison of STAT6 in St. Croix and Suffolk sheep.

Suffolk PBMC significantly upregulated IL-17A after 6 hours of culture with CLA. IL-17A and its receptor were found to be critical for defense against the intestinal protozoan parasite Giardia but promoting IgA production (Dann et al., 2015) and IgA is proposed to be important in resistance to adult $H$. contortus infection (Hernández et al., 2016). IL-17A is most indicated in association with inflammation during infection with extracellular bacteria or fungi as well as in inflammatory disease (Pappu et al., 2011) while IL-17E (IL-25) has been found to promote Th2 responses during infection with the helminth Trichuris (Owyang et al., 2006). IL-25 did not exceed complete media controls in Suffolk PBMC in response to CLA at 6 hours (data not shown). These data indicate an inappropriate activation of an IL-17 family member cytokine in response to $H$. contortus crude larval antigen. Design and testing of primers for Th17 transcription factors STAT3 
and RORyt (Bettelli et al., 2007) would be required to confirm activation of Th17 subset in response to $H$. contortus CLA by Suffolk PBMC.

RNA-Sequencing of St. Croix and Suffolk PBMC after 6 hours of culture with CLA revealed an immense amount of useful data. The staggering difference in number of genes upregulated in St. Croix PBMC compared to Suffolk PBMC (499 vs. 130), largely associated with inflammation, indicates increased activation of St. Croix PBMC. St. Croix PBMC were found to upregulate three toll-like receptors in response to CLA, which may implicate them in recognition of $H$. contortus antigen. None of these genes were found to be upregulated in Suffolk PBMC. In fact, when Suffolk PBMC cultured with CLA are compared to Suffolk complete media controls, all TLR genes are downregulated in CLA culture. In additional, St. Croix PBMC upregulated 5 c-type lectin receptors, another innate receptor. Early recognition of $H$. contortus by St. Croix PBMC may be the key to inducing fast production of IL-4 and activation of Th2 cells leading to decreased FEC and worm burden in St. Croix sheep.

Lack of TLR upregulation may be an an inability of Suffolk PBMC to recognize $H$. contortus antigen, as previously discussed, however it may also be parasite mediated. Parasites, including $H$. contortus, are known to secrete immunomodulators including immune suppressing proteins. However, in this study, cells were exposed to $H$. contortus antigen in the absence of excretory / secretory protein from $H$. contortus larvae and adults, further providing evidence to the inability of Suffolk innate cells to recognize $H$. contortus pathogen associated molecular patterns.

Surprisingly, RNA-Seq revealed CD4+ $T$ cell receptor associated genes upregulated in Suffolk PBMC, which would indicate an activation of T helper cells, though 
it is unclear which subset of T cells. St. Croix PBMC cultured with CLA had upregulated CD44 $(P=0.0005)$, indicating the presence of memory T cells (Curtsinger et al., 1998). While upregulating CD4 TCR, Suffolk PBMC simultaneously expression BTLA, which is an inhibitor of T and B cells (Villen et al., 1997; Gavrieli et al., 2004). Upregulation of BTLA could contribute to a lack of memory response observed in Suffolk sheep as primary and challenge $H$. contortus infections results in no statistical difference in FEC (Jacobs, 2013).

Combination of St. Croix PBMC increased IL-4 production, upregulation of Th2 genes (observed by qPCR), innate pattern recognition receptors, inflammatory genes, presence of memory $\mathrm{T}$ cells and increased activation at an early time are likely to all contribute to the breed's ability to combat $H$. contortus infection. It is unlikely that any single one of these factors alone is responsible for St. Croix's parasite resistance, but each are contributors to resistance. Conversely, inability of Suffolk PBMC to activate a Th2 phenotype, beginning with the IL-4 receptor, despite IL-4 production gives strong indication of dysregulation in the IL-4 signaling pathway. Prior to doubling the concentration of CLA, Suffolk PBMC generated no detectable IL4Ra.

Noticeably, the three most upregulated pathways in St. Croix PBMC (TLR signaling, IL-1 and IL-10, and monocyte signaling) cultured with CLA are associated with antigen presenting cell / macrophage function. While Suffolk PBMC upregulate genes associated with the TCR and TCR signaling is their most upregulated pathway, they simultaneously upregulate genes and pathways associated with lymphocyte suppression. These data make it unlikely Suffolk have a deficiency in lymphocyte activation, but perhaps an antigen recognition or presentation deficiency. 
All of these data taken together highlight several possible areas of deficiency in Suffolk PBMC that may contribute to their susceptibility to $H$. contortus. Suffolk PBMC show a lack of IL-4 receptor, genes for cytokines crucial to parasite expulsion, innate receptors which may be responsible for parasite recognition, and an increase in a gene associated with lymphocyte suppression at an early time point. Much like St. Croix, each of these findings taken together are likely to contribute to susceptibility. Perhaps one of these deficiencies could be overcome by some form of redundancy, which is often found in the immune system, but together they lead to catastrophic failure to respond to $H$ contortus infection. 


\section{Literature Cited}

Bettelli, E., Korn, T., and VK Kuchroo. 2007. Th17: the third member of the effector T cell trilogy. Curr Opin Immunol. 19(6): 652-657.

Burke, JM., Apple, JK., Roberts, WJ, Boger, CB, and EB Kegley. 2003. Effect of breedtype on performance and carcass traits of intensively managed hair sheep. Meat Sci 63(3): 309-315.

Bowdridge, SA., Zajac, AM., and DR Notter. 2015. St. Croix sheep produce a rapid and greater cellular immune response contributing to reduced establishment of Haemonchus contortus. Vet Parasitol. 208(3-4): 204-210.

Courtney, C., Parker, C., McClure, K., and R Herd. 1985. Resistance of nonlambing exotic and domestic ewes to naturally acquired gastrointestinal nematodes Int $\mathrm{J}$ Parasit. 15: 239-243.

Curtsinger, JM., Lins, DC., and MF Mescher. 1998. CD8+ memory T cells (CD44 high , Ly$6 C^{+}$) are more sensitive than naïve cells (CD44low, Ly-6C-) to TCR/CD8 signaling in response to antigen. J Immunol. 160: 3236-3243.

Dann, SM., Manthey, CF., Miyamoto, Y., Gima, L., Abrahim, A., Cao, AT., Hanson, EM., Kolls, JK., Raz, E., Cong, Y., and L Eckmann. 2015. IL-17A promotes protective $\lg \mathrm{A}$ responses and expression of other potential effectors against the lumendwelling enteric parasite Giardia. Exp Parasitol. 156: 68-78.

Else, KJ., and Grencis, RK. 1991. Cellular immune responses to the murine nematode parasite Trichuris muris. Differential cytokine production during acute or chronic infection. Immunology. 72(4): 508-513.

Gavrieli, M., Watanabe, N., Loftin, SK., Murphy, TL., and KM Murphy. 2003. Characterization of phosphotyrosine binding motifs in the cytoplasmic domain and $\mathrm{B}$ and $\mathrm{T}$ lymphocyte attenuator required for association with protein tyrosine phosphatases SHP-1 and SHP-2. Biochem Biophys Res Commun. 312(4): 12361243.

Gamble, H., and A Zajac. 1992. Resistance of St. Croix lambs to Haemonchus contortus in experimentally and naturally acquired infections. Vet Parasitol. 41: 211-225.

Gill, JH., Kerr CA., Shoop WL., and E Lacey. 1998. Evidence of multiple mechanisms of avermectin resistance in Haemonchus contortus-comparison of selection protocols. Int J Parasitol. 28(5): 783-9.

Hernández, JN., Hernández, A., Stear, MJ., Conde-Felipe, M., Rodríguez, E., Piedfrafita, D., and JF González. 2016. Potential role for mucosal lgA in 
modulating Haemonchus contortus adult worm infection in sheep. Vet Parasitol. 223: $153-158$.

Jacobs, JR. 2013. Characterizing peripheral cellular and humoral immune responses to Haemonchus contortus in sheep. Retrieved from ProQuest. 1549753.

Jacobs, JR., Greiner, SP., and SA Bowdridge. 2015. Serum interleukin-4 (IL-4) production is associated with lower fecal egg count in parasite-resistant sheep. Vet Parasitol. 211(1-2): 102-5.

Jacobs, JR., Sommers, KN., Zajac, AM., Notter, DR., and SA Bowdridge. 2016. Early IL-4 gene expression in abomasum is associated with resistance to Haemonchus contortus in hair and wool sheep breeds. Parasit Immunol. 38(6): 333-339.

Kaplan, MH., Wurster, AL., Smiley, ST., and MJ Grusby. 1999. Stat-6 dependent and independent pathways for IL-4 production. J Immunol. 163: 6536-6540.

Lacroux, C., Nguyen, TH., Andreoletti, O., Prevot, F., Grisez, C., Bergeaud, JP., Gruner, L., Brunel, JC., Francois, D., Dorchies, P., and P Jacquiet. 2006. Haemonchus contortus (Nematoda: Trichostrongylidae) infection in lambs elicits an unequivocal Th2 immune response. Vet Res. 37(4): 608-622.

Loke, P., Nair, MG., Parkinson, J., Guiliano, D., Blaxter, M., and JE Allen. 2002. IL-4 dependent alternatively-activated macrophages have a distinctive in vivo gene expression phenotype. BMC Immunol. 3: 7.

MacLeod, MKL., Knappler, JW. And P Marrack. 2010. Memory CD4 T cells: generation, reactivation and re-assignment. Immunol. 130 (1): 10-15.

McLeod, RS. 1995. Costs of major parasites to the Australian livestock industries. Int J Parasitol. 25(11): 1363-1367.

Muñoz-Caro, T., Rubio, MC, Ilva, LMR., Magdowski, G., Gärtner, U., McNielly, TN., Taubert, A., and C. Hermosilla. 2015. Leucocyte-derived extracellular trap formation significantly contributes to Haemonchus contortus larval entrapment.

Parasit Vectors. 8: 607.

Noel, W., Raes, G., Hassanzadeh, GG., De Baetselier, P., and A Beschin. 2004. Alternatively activated macrophages during parasite infection. Trends Parasitol. 20(3): 126-133.

Owyang, AM., Zaph, C., Wilson, EH., Guilt, KJ., McClanahan, T., Miller, HR., Cua, DJ., Goldschmidt, M., Hunter, CA., Kastelein, RA., and D. Artis. 2006. Interleukin 25 regulates type 2 cytokine-dependent immunity and limits chronic inflammation in the gastrointestinal tract. J Exp Med. 203(4): 843-849. 
Pappu, R., Ramirez-Carrozzi, V., and A. Sambandam. 2011. The interleukin-17 cytokine family: critical players in host defence and inflammatory diseases. Immunology. 134(1): 8-16.

Peña, M., Miller, J., and D Horohov. 2004. Effect of dexamethasone treatment on the immune response of Gulf Coast Native lambs to Haemonchus contortus infection. Vet Parsitol. 119: 223-235.

Rincon, G., Farber, EA., Farber, CR., Nkrumah, JD., and JF Medrano. 2009. Polymorphisms in the STAT6 gene and their association with carcass traits in feedlot cattle. Anim Genet. (40(6): 878-882.

Roeber, F., Jex, AR., and RB Gasser. 2013. Impact of gastrointestinal parasitic nematodes of sheep and the role of advanced molecular tools for exploring epidemiology and drug resistance - an Australian perspective. Parasit Vectors. 6:153.

Sackett, D., and P Holmes. Assessing the economic cost of endemic disease on the profitability of Australian beef cattle and sheep producers. Meat and Livestock (MLA) Limited: Sydney; 2006.

Sommers, KN. 2014. Immune related gene expression of parasite-resistant sheep during a Haemonchus contortus infection. Retrieved by ProQuest. 1555016.

Takeda, K., Tanaka, T., Shi, W., Matsumoto, M., Minami, M., Kashiwamura, S., Nakanishi, K., Yoshida, N., Kishimoto, T, and S. Akira. 1996. Essential role of Stat6 in IL-4 signaling. Nature. 18(380): 3894-3901.

Terada, N., Konno, A., Natori, T., Tada, H., and K Togawa. 1993. Interleukin-5 preferentially recruits eosinophils from vessels in nasal mucosa. Acta Otolaryngol Suppl. 506: 57-60.

Terefe, G., Grisez, C., Prevot, F., Bergeaud, JP., Dorchies, P., Brunel, JC., François, D., Fourquax, I., and P. Jacquiet. 2007. In vitro pre-exposure of Haemonchus contortus L3 to blood eosinophils reduces their establishment potential in sheep. Vet Res. 38: 647-654.

Urban, JF., Noben-Trauth, N., Donaldson, DD., Madden, KB., Morris, SC., Collins, M., and FD Finkelman. 1998. IL-13, IL-4Ra, and Stat6 are required for the expulsion of the gastrointestinal nematode parasite Nippostrongylus brasiliensis. Immunity. 8(2): $255-264$.

Vilen, BJ., Famigletti, SJ., Carbone, AM., Kay, BK and JC Cambier. 1997. B cell antigen receptor desensitization: disruption of receptor coupling to tyrosine kinase activation. J Immunol. 59(1): 231-243. 
Wang, W., Wang, S., Zhang, H., Yuan, C., Yan, R., Song, X., Xu, L., and X Li. 2014. Galectin Hco-gal-m from Haemonchus contortus modulates goat monocytes and T cell function in different patterns. Parasit Vectors. 7: 342.

Zheng, W., and RA Flavell. 1997. The transcription factor GATA-3 is necessary and sufficient for Th2 cytokine gene expression in CD4 T cells. Cell. 89(4): 587-596. 


\section{Appendix I}

Short Communication:

Serum interleukin-4 (IL-4) production is associated with lower fecal egg count in parasite-resistant sheep.

Jesica R. Jacobs ${ }^{\dagger}$, Scott P. Greiner ${ }^{\ddagger}$, and Scott A. Bowdridge ${ }^{\dagger, *}$

${ }^{\dagger}$ Division of Animal and Nutritional Sciences, West Virginia University, Morgantown, WV 26505

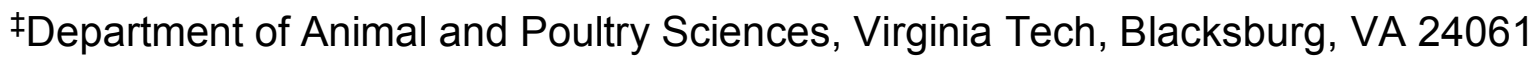

${ }^{*}$ Corresponding Author: Dr. Scott A. Bowdridge, Division of Animal and Nutritional

Sciences, Morgantown, WV 26505, USA, scott.bowdridge@mail.wvu.edu

Keywords: Haemonchus contortus; St. Croix sheep; Parasite resistance, IL-4 


\section{Abstract}

The objective of this experiment was to determine serum interleukin-4 (IL-4) concentration in response to Haemonchus contortus infection in parasite-resistant and -susceptible lambs. St. Croix (STC) (resistant) and Suffolk / Hampshire crossbred (SX) (susceptible) lambs were either not infected $(n=5 / b r e e d)$, given a primary inoculation $(n=5 / b r e e d)$ or challenged infected with $H$. contortus ( $n=5 / b r e e d)$. Each inoculum given consisted of 10,000 L 3 larvae. Blood was collected daily for 14 days and then weekly to day 49 . Feces were collected on day 0 and weekly until day 49. Challenged STC lambs generated significantly lower fecal egg count (FEC) (1520 eggs/g SX vs. $<50$ eggs/gram STC; $P<$ $0.001)$ and had higher PCV (34\% vs. $29 \%$; $P<0.001)$. Serum IL-4 concentrations of primary-infected STC and challenge-infected SX lambs were greater during early infection (days 0-7) than mid (days 14-28) and late (days 35-49) infection, but was significantly reduced $(P<0.001)$ by day 49 . Challenge-infected STC lambs incrementally increased serum IL-4 from early to late infection. Change in serum IL-4 concentration during early, mid and late infection indicated IL-4 concentration in challenge-infected STC lambs increased during mid and late infection. These data demonstrate that parasiteresistant St. Croix sheep generate a potent Th2-response, as measured by elevated serum IL-4 concentration, which is associated with a marked FEC reduction.

\section{Introduction}

Infection with Haemonchus contortus has been shown to elicit a T-helper cell type 2 (Th2) response in sheep, indicated by up-regulation of interleukin 4 (IL-4) and interleukin 13 (IL-13) gene expression (Lacroux et al., 2006, Mackinnon et al., 2015). Adaptive responses are observable by lymph node hypertrophy (Bowdridge et al., 2015), 
increases in $\mathrm{CD}^{+} \mathrm{T}$ cells and B cells (Balic et al., 2000) and increased circulating antibody (Schallig, 2000).

Primary and challenge infection of $H$. contortus in St. Croix sheep demonstrated reduced fecal egg count (FEC) during challenge infection (Courtney et al., 1985). Analysis of immune response during challenge $H$. contortus infection in parasite-resistant sheep was determined to be Th2-mediated (Alba-Hurtado and Muñoz-Guzmán, 2013), with IL4 being the hallmark cytokine. However, in previous studies of immune responses to $H$. contortus in sheep, naïve and single infection animals were not used.

The aim of this experiment was to measure serum IL-4 levels during primary and challenge infections with $H$. contortus in St. Croix and Suffolk crossbred lambs.

\section{Materials and Methods}

\subsection{Maintaining Haemonchus contortus-naïve lambs}

Pregnant St. Croix and Suffolk $x$ Hampshire ewes were housed in a barn constructed with a raised, expanded metal floor. Lambs were born and housed in this facility throughout the experiment. Naïve lambs had a strongylid FEC of $<50$ eggs/gram of feces as measured by modified McMasters technique (Whitlock, 1948) at weaning and throughout the experiment; validating lack of $H$. contortus exposure. All studies were approved by WVU Animal Care and Use Committee protocols 11-0505, 11-0308.

\subsection{Experimental Design}

Four weeks after weaning (approximately 12 weeks of age), naïve lambs of each breed were randomly assigned to one of three infection groups ( $n=5 /$ infection/breed): naïve (never infected), primary (infected once with $H$. contortus on day 0 ) or challenge 
(received a priming and secondary $H$. contortus infection). Three lambs were assigned to the naïve SX (Suffolk / Hampshire cross) treatment group due to limited stock. Additionally, one naive Suffolk-crossbred lamb died from natural causes between experimental days 21 and 28 resulting in only 2 lambs in that group.

To prepare challenge-infected lambs, prior to the experimental day 0 (day -77) infection, they were given a priming infection of $10,000 \mathrm{H}$. contortus $\mathrm{L}_{3}$ and were allowed to be infected for 5 weeks prior to de-worming. Fecal samples were collected weekly. Five weeks after priming infection, Haemonchus-primed lambs were orally administered moxidectin (Boehringer Ingelheim, Ridgefield, CT) at a rate of $0.2 \mathrm{mg} / \mathrm{kg}$ of body weight followed two weeks later with levamisole (AgriLabs, St. Joseph, MO) at a rate of $8 \mathrm{mg} / \mathrm{kg}$ of body weight. Haemonchus-primed lambs were rested for five-weeks prior to start of experiment (day 0 ) with weekly fecal sampling to verify FEC $<50$. On day 0 , lambs in the primary-infection group were given their first and only oral inoculation of $10,000 \mathrm{H}$. contortus $L_{3}$ and challenge-infection groups were given their second inoculation of 10,000 H. contortus $L_{3}$. All larvae administered to lambs were done so experimentally using cultured larvae (as described below) and not via natural infection.

\subsection{Sample Collection}

Blood and fecal samples were collected daily on days $0-14$ then weekly for an additional five weeks (days 21-49) for all experimental animals. Whole blood samples were obtained via jugular venipuncture and collected into a $10 \mathrm{ml}$ untreated vacutainer tube and a $4 \mathrm{ml}$ EDTA treated vacutainer tubes (Tyco, Mansfield, MA) per animal. Blood from untreated tubes was centrifuged $(700 \times g)$ at room temperature and serum collected and stored $\left(-20^{\circ} \mathrm{C}\right)$ for IL-4 analysis. 


\subsection{Parasitological Evaluation}

\subsubsection{Haemonchus contortus larval culture}

Gravid, adult $H$. contortus females were collected from the abomasum of sheep that had recently died of Haemonchosis, pulverized, and eggs were cultured for 7 days at $30^{\circ} \mathrm{C}$. Larvae were collected using a Baermann Apparatus and used to infect three wethers. Feces containing $H$. contortus eggs were collected from these persistently infected lambs. Feces were mixed with sterile peat moss and activated charcoal; then incubated for one week at $30^{\circ} \mathrm{C}$ to develop $\mathrm{L}_{3}$ stage larvae were separated using a Baermann Apparatus (Zajac and Conboy. 2006) and stored in Phosphate Buffered Saline (PBS, $\mathrm{pH} 7.4$ ) at $4^{\circ} \mathrm{C}$.

\subsubsection{Fecal Egg Count}

FEC were performed using the modified McMaster's technique (Whitlock, 1948). Briefly, $56 \mathrm{ml}$ of saturated salt solution was added to $4 \mathrm{~g}$ of feces, homogenized then strained through a double layer of cheese cloth. Strained solution was added to a McMaster's slide and eggs were counted in each grid. Egg count from both grids was multiplied by 50 yielding eggs/gram of feces.

\subsection{Blood and Serum Analysis}

\subsubsection{Packed cell volume}

Whole blood from EDTA treated tubes was added to heparin treated microhematocrit tubes (StatSpin, Westwood MA). Tubes were placed into a microcentrifuge (StatSpin, Westwood MA) and centrifuged for 3 min. Red blood cell percentage was determined by digital hematocrit reading (Stat Spin, Westwood MA). 


\subsubsection{IL-4 ELISA}

IL-4 was quantified by ovine-specific ELISA kit (MyBioSource, San Diego, CA). Undiluted serum was analyzed in duplicate for each animal and the assay was performed per manufacturer's protocol. Absorbance was read at $450 \mathrm{~nm}$ and raw absorbance values for samples and standards were adjusted for blank absorbance. Concentration of IL-4 was calculated using a standard curve with a detection range of $6.25-400 \mathrm{pg} / \mathrm{ml}$, coefficient of variation (CV) of inter and intra-assay was less than $10 \%$.

\subsection{Statistical Analysis}

FEC was normalized by using $\log _{10}(\mathrm{FEC}+25)$ and back transformed for means reporting. Statistical analysis used the General Linear Model (GLM) of SAS version 9.4 (Cary, NC) with fixed effects of infection, breed and time and all two- and three-way interactions were analyzed. Comparisons of least squares means (LSmeans) were performed using the Bonferroni procedure. Data from IL-4 ELISA were log-transformed using $\log _{10}(\mathrm{IL}-4+1)$ and were grouped by times of early (days 0,3 and 7 ), middle (days 14, 21 and 28) and late (days 35, 42 and 49) infection. IL-4 data were analyzed using the GLM procedure of SAS with fixed effects of period (early, mid and late), breed and infection. To calculate delta-IL-4, naïve lamb LSmeans of transformed IL-4 data were subtracted from IL-4 data of primary and challenge infected lambs at each time point. Delta-IL-4 data were analyzed using a one-way ANOVA. Significance was accepted when $P<0.05$. 


\section{Results}

\subsection{Fecal Egg Count}

Primary-infected STC lambs generated a peak FEC of 3210 eggs/gram feces on day 28 before reducing to $<50$ eggs/gram feces by day 35 and challenge-infected STC lambs generated a FEC of $<50$ eggs/gram (Fig. 1A). There was no significant FEC difference between primary and challenge-infected SX lambs (Fig. 1B). Naïve lambs of each breed remained at $<50$ eggs/gram for the duration of the experiment (data not shown).

\subsection{Packed Cell Volume}

Primary and challenge-infected STC lambs maintained a higher PCV than primary and challenge-infected SX lambs from day 28 to day $49(P<0.05$, Figure $1 \mathrm{C})$. On average, STC lambs had significantly higher PCV than SX lambs $(P<0.001)$. Within breeds, primary-infected STC lambs maintained higher PCV than challenge-infected STC lambs $(P<0.05)$. There were no significant differences between SX primary and challenge-infected lambs.

\subsection{Serum IL-4 ELISA}

Analysis of serum IL-4 revealed no significant concentration difference in naïve lambs over time (Fig 2A). Yet analysis of early infection (days $0-7$ ) indicated primaryinfected STC and challenge-infected SX lambs had significantly greater IL-4 concentration $(P<0.001)$ compared to later stages of infection within breed $(1.97$ and $2.44 \mathrm{pg} / \mathrm{ml}$ respectively). Primary-infected SX lambs had greater IL-4 concentration during early and late $(1.91$ and $1.51 \mathrm{pg} / \mathrm{ml})$ infection but decreased during mid-infection $(0.97 \mathrm{pg} / \mathrm{ml} ; P<0.001)$. There was no significant effect of time on IL-4 concentration in 
challenge-infected STC lambs, yet an evident trend was observed from beginning to late stage of infection. This prompted the comparison of primary and challenge infection IL-4 concentration to that of naïve lambs within breed. During early infection (Fig. 2B) challenge-infected SX had the greatest change from naïve lambs, whereas primaryinfected SX lambs were lowest. During mid (Fig. 2C) and late (Fig. 2D) infection only challenge-infected STC lambs had greater IL-4 concentration compared to naïve lambs $(P<0.001)$.

\section{Discussion}

Fecal egg count of STC lambs was reduced to $<50$ by 5 weeks after primary infection and challenge-infected STC lambs had a FEC of $<50$ throughout the experiment. These data confirm results indicating potent parasite-resistance in STC sheep (Courtney et. al., 1985). Additionally, primary and challenge-infected STC lambs had elevated PCV compared to primary and challenge-infected SX lambs consistent with a previous report indicating higher PCV of Caribbean hair sheep during H. contortus infection (Vanimisetti et al., 2004). Thus, greater baseline PCV is a potential physiological mechanism developed as a result of constant $H$. contortus challenge in STC lambs.

IL-4 is critical for the development of protective immunity to helminth infections in mice (Svetic et al., 1993). Depleting $\mathrm{CD}^{+}$cells, known to produce high levels of IL-4 (King and Mohrs, 2009), in Gulf Coast Native sheep resulted in greater establishment of H. contortus (Pena et al., 2006). Serum IL-4 has been measured in breeds resistant or susceptible to Echinococcus granulosus, and results indicated no difference in serum IL4 concentration (Li et al., 2011). Measurement of serum IL-4 during $H$. contortus infection has not been previously reported between resistant and susceptible breeds. 
Surprisingly, IL-4 serum concentration was greater in challenge-infected SX and primary-infected STC lambs during early $H$. contortus infection, but declined rapidly during mid and late-infection. IL-4 concentration increased during mid and late infection in challenge-infected STC lambs. These data differ somewhat from murine models in which immune challenged mice generate higher serum IL-4 concentration early and is sustained until the clearance of the parasite (Finkleman et al.,2000). The lack of early IL4 in challenge-infected STC lambs is interesting as reports of IL-4 gene expression was higher in lambs challenged with $H$. contortus early after infection (Meeusen et al., 2005). Thus, it may be reasonable to conclude that IL-4 is generated early at local site of infection and present later in serum in resistant-immunized sheep. These data indicate the change in IL-4 of challenge-infected STC lambs is associated with marked reduction in FEC.

\section{Conflict of Interest}

The authors declare no conflicts of interest.

\section{Acknowledgements}

This project funded through a grant from USDA-NIFA \#2011-02949. 


\section{References:}

Alba-Hurtado, F., and M. Muñoz-Guzmán. 2013. Immune responses associated with resistance to haemonchosis in sheep. BioMed Res. Int. 2013: 162158.

Balic, A., V. Bowles, and E.N. T. Meeusen. 2000. Cellular profiles in the abomasal mucosa and lymph node during primary infection with Haemonchus contortus in sheep. Vet. Immunol. Immunopath. 75: 109-120.

Bowdridge, S. A., A. M. Zajac and D. R. Notter. 2015. St. Croix sheep produce a rapid and greater cellular immune response contributing to reduced establishment of Haemonchus contortus. Vet. Parasitol. 208: 204-210.

Courtney, C., C. Parker, K. McClure, and R. Herd. 1985. Resistance of nonlambing exotic and domestic ewes to naturally acquired gastrointestinal nematodes. Int. J. Parasit. 15: 239-243.

Finkleman, F. D., S.C. Morris, T. Orehhova, M. Mori, D. Donaldson, S.L. Reiner, N.L. Reilly, L.Schopf and J.F. Urban, Jr. 2000. Stat6 regulation of in vivo IL-4 responses. J. Immunol. 164: 2303-2310.

King, I.L., M. Morhs. 2009. IL-4 producing CD4+T cells in reactive lymph nodes during helminth infection are T follicular helper cells. J. Exp. Med. 206: 1001-1007.

Lacroux, C., T. Nguyen, O. Andreoletti, F. Prevot, C. Grisez, J.-P. Bergeaud, L. Gruner, J.-C. Brunel, D. Francois, P. Dorchies, and P. Jacquiet. 2006. Haemonchus contortus (Nematoda: Trichostrongylidae) infection in lambs elicits an unequivocal Th2 immune response. Vet. Res. 37: 607-622.

Li, R., Q. Peng, B. Jia, G. Shi, Z. Zhao, H. Shen and H. Li. 2011. Anitbody and cytokine responses to hydatid in experimentally infected Kazakh sheep with hydatodosis resistant haplotype. Parasitol. Res. 108:1131-1137

Mackinnon, K.M., S. A. Bowdridge, I. Kanevsky-Mullarky, A.M. Zajac, and D.R. Notter. 2015. Gene expression profiles of hair and wool sheep reveal importance of Th2 immune mechanisms for increased resistance to Haemonchus contortus. J. Anim. Sci. In Press doi: 10.2527/jas2014-8652

Meeusen, E.N.T., A. Balic and V. Bowles. 2005. Cells, cytokines and other molecules associated with rejection of gastrointestinal nematode parasites. Vet. Immunol. Immunopathol. 108:121-125.

Pena, M.T., J. E. Miller, and D. W. Horohov. 2006. Effect of CD4+T lymphocyte depletion on resistance of Gulf Coast Native lambs to Haemonchus contortus. Vet. Parasitol. 138: 240-246. 
Schallig, H. 2000. Immunological responses of sheep to Haemonchus contortus. Parasitol. 120 Suppl: 63-72.

Svetic, A., K. B. Madden, X. D. Zhou, P. Lu, I. M. Katona, and F. D. Finkelman. 1993. A primary intestinal helminthic infection rapidly induces gut-associated elevation of Th2-associated cytokines and IL-3. J. Immunol. 150: 3434-3441.

Vanimisetti, H., S. Greiner, A. Zajac, and D. Notter. 2004. Performance of hair sheep composite breeds: resistance of lambs to Haemonchus contortus. J. Anim. Sci.82: 595-604.

Whitlock, H.V., 1948. Some modifications of the McMaster helminth egg-counting technique apparatus. J. Coun. Sci. Ind. Res. 21:177-180.

Zajac, A., and G. Conboy. 2006. Veterinary Clinical Parasitology. 8 ed. Wiley-Blackwell, Oxford, UK.

Figure 1

A

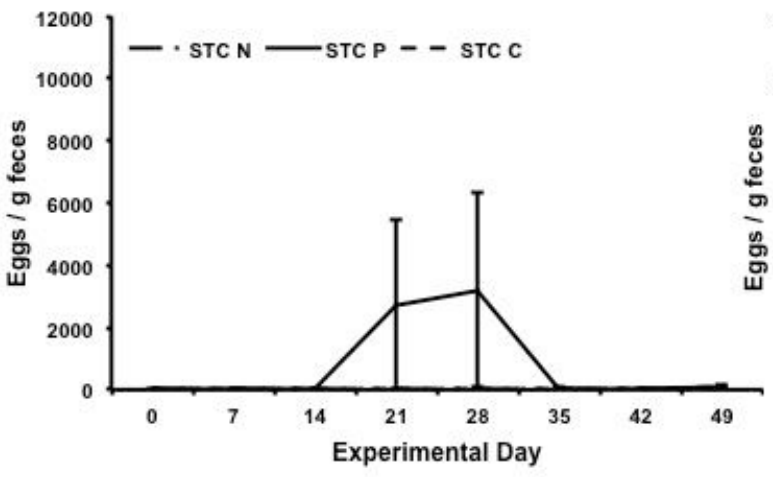

B

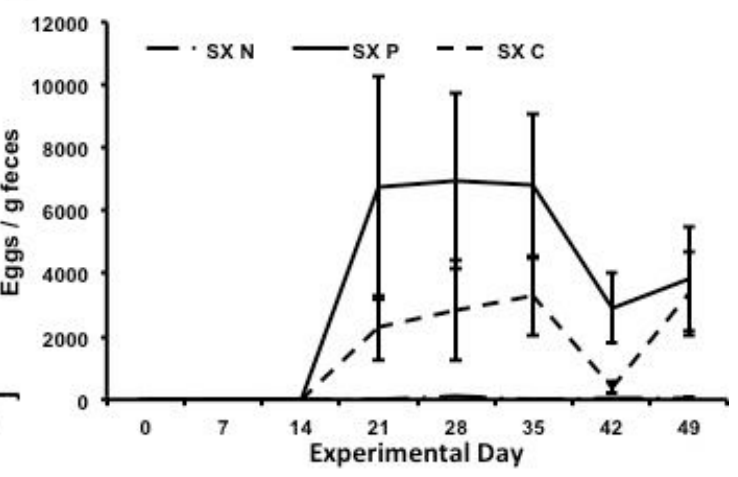

C

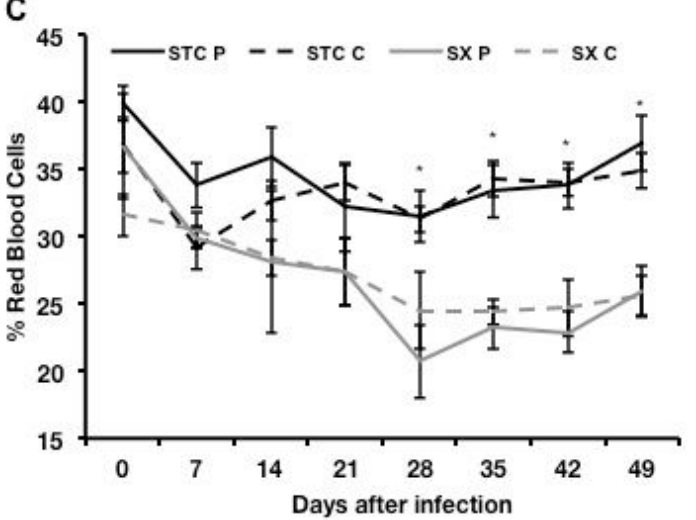


Figure 2
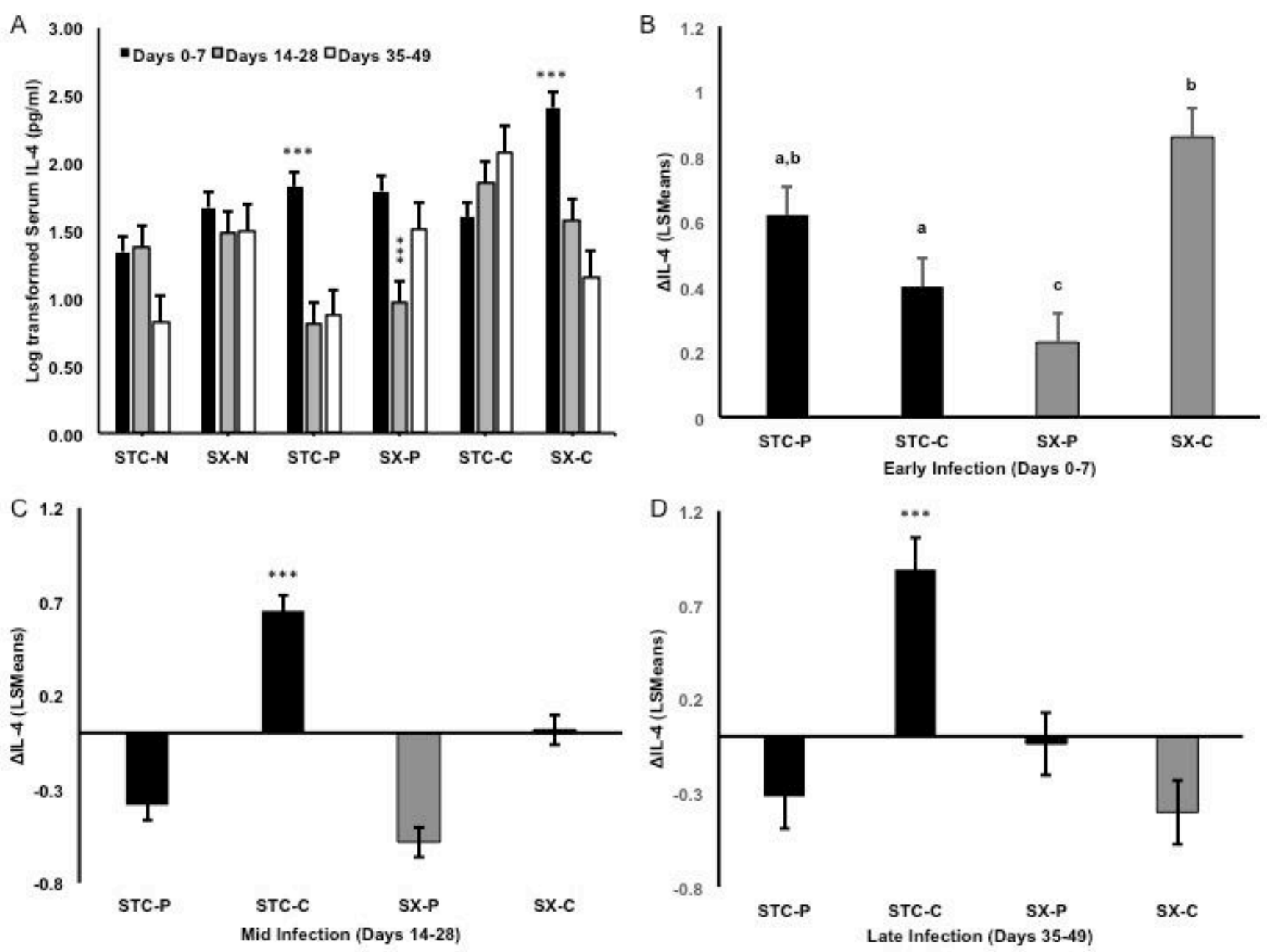


\section{Appendix II}

Early IL-4 gene expression in abomasum is associated with resistance to Haemonchus contortus in hair and wool sheep breeds.

Jesica R. Jacobs ${ }^{1}$, Karen N. Sommers ${ }^{1}$, Anne M. Zajac², David R. Notter ${ }^{3}$, Scott A. Bowdridge $^{1, *}$

${ }^{1}$ Division of Animal and Nutritional Sciences, West Virginia University, Morgantown, WV 26506, USA

2Department of Biomedical Sciences and Pathobiology, Virginia Tech, Blacksburg, VA 24061, USA

${ }^{3}$ Department of Animal and Poultry Sciences, Virginia Tech, Blacksburg, VA 24061, USA

* Corresponding author: Dr. Scott Bowdridge, G050 Agricultural Sciences BIdg, West Virginia University, Morgantown, WV 26506, USA; Scott.Bowdridge@mail.wvu.edu, (304)293-2003

DECLARATION: The authors declare no conflicts of interest.

Keywords: Haemonchus contortus, St. Croix sheep, Th2 immunity 


\section{Abstract}

Early immune events associated with reduced larval burden remain unclear in parasiteresistant breeds of sheep. Therefore, our objective was to determine breed differences in immune-related gene expression following infection with $H$. contortus. Gene expression in abomasal tissue and mucosa, and in abomasal lymph nodes (ALN) was measured in 24 St. Croix (hair) lambs and 24 Dorset x (Finn-Rambouillet) (wool) lambs at 0, 3, 5 and 7 days after infection with 10,000 L3 H. contortus larvae. Expression of IL-4 in abomasal mucosa was detected on day 3 and increased to day 7 in hair lambs, but was not detectable in wool lambs. Genes that recruit neutrophils (CXCL1) and macrophages (MCP1) were upregulated in abomasal mucosa of hair lambs. Genes associated with alternative macrophage activation (ARG-1) and eosinophil activation (Gal-14) were also upregulated in the abomasal mucosa of hair lambs. Tissue remodeling genes (MMP13) and (PDGF) in addition to tumor necrosis factor alpha (TNFo) and $M C P 1$ were upregulated in abomasal tissue of wool lambs; these lambs also had greater expression of forkhead box P3 in ALN. These data indicate a role for early IL-4 expression locally and demonstrate potential down-regulation of immunity in wool sheep that could facilitate establishment of $H$. contortus. 


\section{Introduction}

When compared to temperate wool sheep breeds, St. Croix hair sheep have consistently generated markedly lower fecal egg counts (FEC) during challenge infections with Haemonchus contortus $(1,2,3)$ and are generally considered resistant to gastrointestinal nematodes (GIN). Reduced FEC observed during challenge infection are likely a result of lower larval establishment (4). To determine immune mechanisms involved in enhanced resistance to GIN, it is therefore imperative to consider responses to infective larvae expressed in the first seven days following infection.

A comparison of immune responses to $H$. contortus infection in St. Croix hair and temperate wool lambs reported that IL-13 and FCERI were upregulated by day 3 after infection in draining lymph nodes and abomasal mucosa (5). Additionally, by 7 days after infection, St. Croix lambs had greater lymph-node hypertrophy, circulating and local neutrophil accumulation, white blood cell count, and serum IgA than GIN-susceptible wool lambs (4). St. Croix lambs had greater circulating serum IL-4 than Suffolk lambs after day 14 post-infection, and their IL-4 levels continued to increase to day 49 (3). Similarly, murine infection with Heligmosmoides polygyrus - bakeri, revealed that early upregulation of Th2-type cytokines in the enteric region (6) was associated with worm expulsion. Taken together these data present a strong argument that the initiation of a robust Th2type immune responses is a critical difference between GIN-resistant and susceptible sheep.

Microarray analyses have identified a multitude of genes that differ in expression between resistant and susceptible sheep types (7). However, these studies have not 
evaluated expression levels in the first few days after infection. Therefore, this study focused on gene expression in mesenteric lymph nodes and abomasal mucosa at 0, 3, 5 and 7 days after $H$. contortus infection in parasite-resistant St. Croix and parasitesusceptible Dorset x (Finnsheep-Rambouillet) crossbred sheep.

\section{Materials and Methods}

\section{Animals and Experimental Design}

Twenty-four spring-born St. Croix hair sheep (hair) and 24 composite wool lambs from the Virginia Tech Sheep Center were used for this experiment. Wool lambs (wool) were composed of $50 \%$ Dorset, 25\% Finnsheep and 25\% Rambouillet breeding and considered susceptible to $H$. contortus $(8,9)$. After weaning lambs grazed naturally infected pastures for approximately 30 days, and, to ensure that all lambs had been exposed to $H$. contortus, each lamb also received a weekly dose of $2,000 H$. contortus $L_{3}$ larvae for 4 weeks before the experiment began. Lambs were dewormed by oral administration of levamisole $(8 \mathrm{mg} / \mathrm{kg})$ and maintained in drylot. Fecal egg counts (FEC) were monitored for three consecutive weeks before starting the experiment to ensure that FEC were less than 50 eggs/g.

Lambs were randomly assigned to treatments within three blocks. Blocking was necessary because all lambs could not be euthanized on a single day. Lambs within each block were infected with $10,000 \mathrm{H}$. contortus L3 larvae and sacrificed at $0,3,5$, or 7 days after infection. Lambs were housed in elevated pens with expanded metal floors from 1 week before experimental infection until sacrifice and fed a $16 \%$ crude protein cornsoybean meal ration, grass hay and water ad libitum throughout the experiment. Lambs were humanely euthanized using captive bolt-gun stunning followed by exsanguination. 
All samples were collected at the Virginia Tech Meats Laboratory. The Virginia Tech Institutional Animal Care and Use Committee approved methods of infection, sample collection and euthanasia used in this study.

\section{Sample Collection}

On the day of sacrifice, all palpable lymph nodes were extracted from the lesser curvature of the abomasum and superficial fat was removed. The largest lymph node from each lamb was cut longitudinally, and a 4-mm slice was placed in RNAlater ${ }^{\text {TM }}$ (Invitrogen,

Burlington, ONT Canada) and stored at $-20^{\circ} \mathrm{C}$ until analysis. The abomasum was cut along the greater curvature and contents were removed and washed gently in PBS $\mathrm{pH}$ 7.4). A section of the fundic region of the abomasum including a fold and all associated connective tissue was removed, placed in RNAlater ${ }^{\mathrm{TM}}$, and stored at $-20^{\circ} \mathrm{C}$. Samples of abomasal mucosa were collected from the fundic region by scraping with a glass slide and stored in RNAlater ${ }^{\mathrm{TM}}$ at $-20^{\circ} \mathrm{C}$ until analysis.

\section{RNA Isolation and cDNA Preparation}

Total RNA was isolated from abomasal mucosa, abomasal lymph node, and abomasal fold tissues. Briefly, $100 \mathrm{mg}$ of tissue was homogenized in $1.5 \mathrm{~mL}$ of RNAzol-bee (TelTest, Friendswood, TX). Then $150 \mu \mathrm{L}$ of chloroform/isoamyl (Sigma-Aldrich, St. Louis, MO) was added to the homogenate and vortexed for 15 seconds, followed by incubation on ice for 5 minutes. Samples were centrifuged for 15 minutes at $14,000 \times g$ at $4^{\circ} \mathrm{C}$. The aqueous layer was retained and placed in a new tube. RNA was precipitated with an equal volume of isopropanol and incubated on ice for 15 minutes. Samples were then centrifuged for 15 minutes at $14,000 \times g$ at $4^{\circ} \mathrm{C}$, washed twice with $1 \mathrm{~mL}$ of $75 \%$ ice-cold ethanol, dried, and dissolved in 20 to $50 \mu$ l of DEPC-treated water. RNA quality was 
determined by NanoDrop ${ }^{\mathrm{TM}} 1000$ Spectrophotometer (Thermo Scientific, Wilmington, DE). Samples with an OD 260:280 ratio of $>1.8$ were diluted in $13 \mu \mathrm{L}$ of DEPC-treated water to a total concentration of $1.8 \mu \mathrm{g}$. Synthesis of cDNA was accomplished by creating a master mix including $2.5 \mu \mathrm{L}$ of $2.5 \mathrm{nM}$ dNTP (GE Illustra, Buckinghamshire, UK), $5.0 \mu \mathrm{L}$ $5 \mathrm{X}$ reverse transcriptase buffer (Life Technologies, Burlington, ONT Canada), 2.0 $\mathrm{L}$

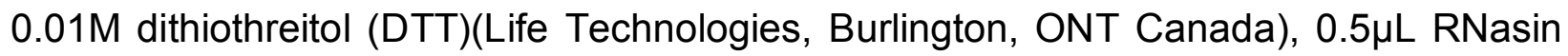
(Promega, Madison, WI), and 2.0 $\mu \mathrm{L}$ random hexamer primers (Life Technologies, Burlington, ONT). Master mix $(12 \mu \mathrm{L})$ was added to $13 \mu \mathrm{L}$ of RNA and samples were denatured at $70^{\circ} \mathrm{C}$ for 5 minutes and then chilled at $4^{\circ} \mathrm{C}$ for 5 minutes using a T100 thermal cycler (Bio-Rad, Hercules, CA). Then $1 \mu \mathrm{L}$ of SuperScript ${ }^{\mathrm{TM}}{ }^{\mathrm{II}}$ reverse transcriptase (Life Technologies, Burlington, ONT Canada) was added to each sample. The reverse transcription reaction was completed by heating to $37^{\circ} \mathrm{C}$ for 60 minutes, $90^{\circ} \mathrm{C}$ for 5 minutes, then cooling to $4^{\circ} \mathrm{C}$ for 5 minutes. Final cDNA preparations were stored at $-20^{\circ} \mathrm{C}$.

\section{Primer Design and Efficiency}

Primer design was based on known mRNA sequences stored in the $\mathrm{NCBI}$ database. For each candidate gene, primers were selected using Primer-3 software (10). The following changes were applied to the default program parameters: 1) product size ranged from 80 to $120 \mathrm{bp} ; 2$ ) primer melting temperatures were 59 to $61^{\circ} \mathrm{C}$; 3) primer GC\% was 40 to $60 \%$; 4) maximum self-complementarity was 3 ; 5) maximum 3' selfcomplementarity was 1 ; and 6) maximum consecutive mononucleotides (poly-x) was 3 . Genes associated with GenBank accession numbers and sequence of primers used for quantitative PCR (qPCR) are listed in Table 1. With the exception of interleukin-5 (11), 
original primers were used. Efficiency was derived from a regression line fitted to a subset of baseline-corrected data points in the log-linear phase of the reaction using LinRegPCR (12). Efficiency $(E)$ for each primer was greater than $(1+E)=1.96$. Melting curve analysis confirmed a single well-defined peak for each reaction, indicating amplification of a sole PCR product. Melting temperatures $(\mathrm{Tm})$ of products were consistent with theoretical Tm of the expected PCR products. Only one band was visualized after agarose gel electrophoresis for all amplified products (data not shown).

\section{Quantitative PCR}

Samples were analyzed in duplicate using the CFX96 system (Bio-Rad, Hercules, CA). Reaction was carried out in a total volume of $20 \mu$ l, containing $10 \mu \mathrm{L}$ (SYBR Green ${ }^{\mathrm{TM}}$ ) Select Master Mix (Life Technologies, Burlington, ONT Canada), $1.2 \mu \mathrm{L}$ of each forward and reverse primers, $2 \mu \mathrm{L} 10 \mathrm{ng} / \mu \mathrm{L}$ diluted cDNA template, and $5.6 \mu \mathrm{L}$ DEPC-treated water. The qPCR conditions were $50^{\circ} \mathrm{C}$ for 10 minutes followed by an initial denaturation at $95^{\circ} \mathrm{C}$ for 5 minutes, then 40 cycles of denaturation at $95^{\circ} \mathrm{C}$ for 10 seconds and extension for 30 seconds at $60^{\circ} \mathrm{C}$. Relative fold changes in expression of candidate genes were derived using the $2^{-\Delta \Delta C t}$ method (13). The Ct values were used to calculate $\Delta \mathrm{Ct}$ values for genes of interest [Ct (test) - Ct (reference)]. The reference gene used for normalization was GADPH. The $\triangle \Delta \mathrm{Ct}$ values were obtained in reference to the Day 0 animals. Graphical representation for each gene was based on fold change.

\section{IL-4 ELISA Assay}

Serum IL-4 was quantified using an ovine-specific ELISA kit (MyBioSource, San Diego, CA). Undiluted serum was analyzed in duplicate for each animal and the assay was performed per manufacturer's protocol. Absorbance was read at $450 \mathrm{~nm}$ and raw 
absorbance values for samples and standards were adjusted for blank absorbance. Concentrations of IL-4 were calculated using a standard curve with a detection range of 6.25 to $400 \mathrm{pg} / \mathrm{ml}$. Inter- and intra-assay coefficients of variation were less than $10 \%$.

\section{Statistical analysis}

Data were analyzed using SigmaPlot (Systat Software, Inc., San Jose, CA). Statistical analysis for $\mathrm{qPCR}$ data was based on $\log _{2}(\Delta \mathrm{Ct})$ values, but results were reported as foldchanges from the reference class, defined as the value for each breed type at day 0 . Preliminary analyses revealed that the blocking variable did not significantly affect expression. Data were thus analyzed using a two-way analysis of variance ( ANOVA) with main effects of breed, time, and breed $\mathrm{x}$ time interaction. Means were compared using a Bonferroni test statistic; differences with $P \leq 0.05$ were considered statically significant.

\section{Results}

\section{Gene expression in abomsal lymph nodes}

Table 1 lists the genes analyzed in the following experiments and associated gene acronyms will be used throughout the text. Of the genes that were analyzed (Table 1), only the FOXP3 transcription factor was differentially expressed between breeds in local lymph nodes. Wool lambs had greater expression of FOXP3 compared to hair lambs ( $P$ $<0.05$; Figure 1). The breed by time interaction was not significant.

\section{Gene expression in full-thickness abomasal tissue}

Analysis of abomasal tissue from the fundic region revealed differential expression of several genes between hair and wool lambs, but breed $\mathrm{x}$ time interaction was not significant for any gene. Across measurement times, wool lambs had greater expression 
of MMP13, MCP1, TNFa, and PDGF genes compared to hair lambs (Table 2). No genes were significantly upregulated in the abomasal tissue of hair sheep.

\section{Gene expression in abomasal mucosa}

Striking differences in Th2 cytokine gene expression in abomasal mucosa were observed between breed types. Expression of IL4 was not detectable in hair sheep until day 3 thus all comparisons of fold-changes were made relative to that time point. Expression of IL4 was up-regulated on days 3, 5 and 7 in St. Croix lambs (Figure 2A), but IL4 expression was not detected in abomasal mucosa of wool lambs at any measurement time. A significant breed effect was also observed for IL5, again with no detectable IL5 expression in wool lambs (Figure 2B). Compared to wool lambs, St. Croix hair lambs also had greater expression of $C X C L 1(P<0.05$, Figure $2 \mathrm{C})$ and $M C P 1(P<0.05$, Figure 2D) in abomasal mucosa. St. Croix lambs also displayed upregulation of $A R G 1(P<0.05)$ and GAL14 $(P<0.05)$ in abomasal mucosa (Table 3).

In comparison with hair lambs, wool lambs displayed upregulation of $A N X A 3, V E G F$, IL-3, IL-6, TNF- $\alpha, C X C R 3$, and $C 3$ (all $P<0.01)$ and of WC.1 and PPARY (both $P<0.05)$ across all time points in the mucosa of the absomasum (Table 3).

\section{Circulating serum IL-4}

A significant breed by time interaction was observed for circulating serum IL-4 ( $P=$ 0.002), indicating a breed effect on the pattern of change in IL-4 following infection. In both breed types, relatively high levels of IL-4 were observed in serum from uninfected lambs, and IL-4 levels declined by 3 days after infection (Table 4). Serum IL-4 then increased after day 3, with higher serum IL-4 in hair lambs by day $7(P<0.05)$. 


\section{Discussion}

Mechanisms controlling the development immunity to GIN between parasite-resistant and parasite-susceptible sheep are not well understood. Sheep typically respond to $H$. contortus infection with a T-helper type 2 immune response (14) and the timing of the response may be vital to worm expulsion. Our data revealed parasite-resistant St. Croix sheep upregulated expression of $I L-4$, an essential cytokine to Th2 development (15), by day 3 of infection. These data were consistent with our recent finding that circulating IL-4 increased in St. Croix sheep by day 7 of infection (3). St. Croix sheep also upregulated expression of $I L-5$, the cytokine that is largely responsible for eosinophil activation (16).

An increase in expression of $M C P 1$ and $A R G 1$ in hair lambs suggests differentiation of alternatively activated macrophages. Murine studies have shown that alternatively activated macrophages are an early source of IL-4 in parasite infections (17), and therefore may assist in Th2 differentiation. Greater expression in CXCL1 (18), in hair sheep was consistent with published findings of increased neutrophil recruitment in St. Croix sheep during $H$. contortus infection (4). Neutrophils have been found to produce IL4 during helminth parasite infections (19). Additionally, St. Croix sheep had greater expression of $G A L 14$, recognized to be a parasite-specific immune mediator in ruminants (20). These data indicate that St. Croix sheep initiate an early, local Th2 immune response during the first 7 days of $H$. contortus infection.

Genes that were preferentially expressed in wool lambs during the first 7 days of infection were those support innate cell signaling and a response to damage caused by invading parasites. Genes cited to play roles in angiogenesis include VEGF and PDFG (21), while $P P a R y$ is important in adipogenesis and MMP13 is expressed in remodeling 
tissues (22). The response to tissue damage in wool sheep is further intensified by increased expression of the inflammatory cytokines TNF $\alpha$ and IL6. Up-regulation of ANXA3 may also enhance inflammation, as it is associated with granule fusion and degranulation of immune cells (23). Additionally, the up-regulated expression of IL3, $M C P 1$, and $C 3$ further supports the involvement of innate cell signaling and innate immunity in the response to infection in wool lambs.

Marked lack of Th2 differentiation in wool lambs may be the result of increased FOXP3 expression in the local draining lymph node. FOXP3 is a transcription factor involved in regulation of T-cell differentiation (24). In addition to inducing an environment consistent

with immunoregulation, FOXP3 also inhibits expression of GATA3, the primary Th2 transcription factor (25).

Taken together, these data indicate important differences in the immune response in parasite-susceptible and resistant sheep. Resistant St. Croix sheep initiate an early Th2 immune profile which may lead to the development of adaptive immunity and be associated with their low larval and adult worm burdens and FEC (4). In contrast, wool sheep upregulate a regulatory profile, which could be the result of immunomodulation by the parasite itself $(26)$.

\section{Acknowledgements}

This project was supported by the following grants: USDA-NIFA 2011-02949, USDA-NIFA OREI 2012-51300-20320. 


\section{References}

[1] Courtney, C., C. Parker, K. McClure, and R. Herd. 1984. Resistance of nonlambing exotic and domestic ewes to naturally acquired gastrointestinal nematodes. Int. J. Parasit. 15(3):239-43.

[2] Gamble, H., and A. Jajac. 1992. Resistance of St. Croix lambs to Haemonchus contortus in experimentally and naturally acquired infection. Vet. Parasitol. Immunopath. 4(3-4):211-25.

[3] Jacobs, J. R. S. P. Greiner, and S. A. Bowdridge. 2015 Serum interleukin-4 (IL-4) is associated with lower fecal egg count in parasite-resistant sheep. Vet. Parasitol. 211(1-2):102-5.

[4] Bowdridge, S. A., Zajac, A. M., and D. R. Notter. 2015. St Croix sheep produce rapid and greater cellular immune response contributing to reduced establishment of Haemonchus contortus. Vet. Parasitol. 208(3-4):204-10.

[5] MacKinnon, K., A. Zajac, F. Kooyman, and D. Notter. 2010. Differences in immune parameters are assocaited with resistance to Haemonchus contortus in Caribbean hair sheep. Parasit. Immunol. 32(7): 484-93.

[6] Svetic, A., K. B. Madden, X. D. Zhou, P. Lu, I. N. Katona, F. D. Finkelman, J. F. Urban, and W. C. Gause. 1993. A primary intestinal helminthic infection rapidly induces a gut-associated elevation of Th2-associated cytokines and IL-3. J. Immunol. 150(8 Pt 1):3434-41.

[7] Rowe, A., C. Gondro, D. Emery, and N. Sangster. 2009. Sequential microarray to identify fiming of molecular responses to Haemonchus contortus infection in sheep. 161(1-2):76-87.

[8] Notter, D. R., Andrew, S. A., and Zajac, A. M. 2003. Responses of hair and wool sheep to a single fixed dose of infective larvae of Haemonchus contortus. Small Ruminant Res. 47:221-225.

[9] Vanimisetti, H. B., Greiner, S. P., Zajac, A. M., and Notter, D. R. 2004. Performance of hair sheep composite breeds: resistance of lambs to Haemonchus contortus. J. Anim. Sci. 82:595-604.

[10] Rozen, S. and H. Skaletsky. 2000. Primer3 on the WWW for general users and for biologist programmers. Methods Mol. Bio. 132:365-86.

[11] Robinson, N., J. Pleasance, D. Piedrafita, and E. N. Meeusen. 2011. The kinetics of local cytokine and galectin expression after challenge infection with the gastrointestinal nematode, Haemonchus contortus. Int. J. Parasitol. 41(5):487-93.

[12] Ramakers, C., J. Ruijter, R. Deprez, and A. Moorman. 2003. Assumption-free analysis of quantitative real-time polymerase chain reaction (PCR) data. Neurosci. Lett. 339(1):62-6.

[13] Livak, K.J., T.D. Schmittgen. 2001. Analysis of relative gene expression data using real-time quantitative PCR and the $2^{-\triangle \Delta C_{T}}$ method. Methods. 25:402-408.

[14] Lacroux, C., T. Nguyen, O. Andreoletti, F. Prevot, C. Grisez, J. P. Bergeaud, L. Gruner, J. C. Brunel, D. Francois, P. Dorchies, and P. Jacquiet. 2006. Haemonchus contortus (Nematoda: Trichostrongylidae) infection in lambs elicits an unequivocal Th2 immune response. Vet. Res. 37(4):607-22. 
[15] Boulay, J. L. and W. E. Paul. 1992. The interleukin-4 family of lymphokines. Curr. Opin. Immunol. 4(3): 294-98.

[16] Clutterbuck, E., J. G. Shields, J. Gordon, S. H. Smith, A. Boyd, R. E. Callard, H. D. Campbell, I. G. Young, and C. J. Sanderson. 1987. Recombinant human interleukin 5 is an eosinophil differentiation factor but has no activity in standard human B cell growth factor assays. Eur. J. Immunol. 17(12): 1743-50.

[17] La Flamme, A., M. Kharkrang, S. Stone, S. Mirmoeini, D. Chuluundorj, and R. Kyle. 2012. Type II-activated murine macrophages produce IL-4. PLoS One. 7(10):e46989.

[18] Schumacher, C., I. Clark-Lewis, M. Baggiolini, and B. Moser. 1992. High- and lowaffinity binding of GRP alpha and neutrophil-activating peptide 2 to interleukin 8 receptors on human neutrophils. Proc Natl Acad. Sci. U.S.A. 89(21):10542-6.

[19] Brandt, E., G. Woerly, A. B. Younes, S. Louiseau, and M. Capron, 2000. IL-4 production by human polymorphonuclear neutrophils. J. Leukoc. Biol. 68(1): 12530.

[20] Preston, S., J. Dunphy, T. Beddoe, E. Meeusen, and A. Young. 2015. Evaluation of the role of galectins in parasite immunology. Methods Mol. Biol. 1207:371-95

[21] Benjamin, L., I. Hemo, and E. Keshet. 1998. A plasticity window for blood vessel remodelling is defined by pericyte coverage of the preformed endothelial network and is regulated by PDGF-B and VEGF. Development (Cambridge, England) 125: 1591-1598.

[22] Toriseva, M. M. Laato, O. Carpen, S. T. Ruohonen, E. Savontaus, M. Inada, S. M. Krane, and V. M. Kahari. 2012. MMP-13 regulates growth of wound granulation tissue and modulates gene expression signatures involved in inflammation, proteolysis, and cell viability. PLoS One. 7(8): e42596.

[23] Le Cabec, V. and I. Maridonneau-Parini. 1994. Annexin 3 is associated with cytoplasmic granules in neutrophils and monocytes and translocates to the plasma membrane in activated cells. Biochem. J. 303(Pt 2): 481-7.

[24] Fontenot, J. D., J. P. Rasmussen, L. M. Williams, J. L. Dooley, A. G. Farr, and A. Y. Rudensky. 2005. Regulatory $T$ cell lineage specification by the forkhead transcription factor foxp3. Immunity. 22(3):329-41.

[25] Rudra, D., P. deRoos, A. Chaudhry., R. E. Niec, A. Arvey, R. M. Samstein, C. Leslie, S. A. Shaffer, D. R. Goodlett, and A. Y. Rudensky. 2012. Transcription factor Foxp3 and its protein partners form a complex regulatory network. Nat. Immunol. 13(10):1010-9.

[26] Maizels, R. M. and M. Yazdanbakshs. 2003. Immune regulation by helminth parasites: cellular and molecular mechanisms. Nat. Rev. Immunol. 3(9):733-44. 
Figures

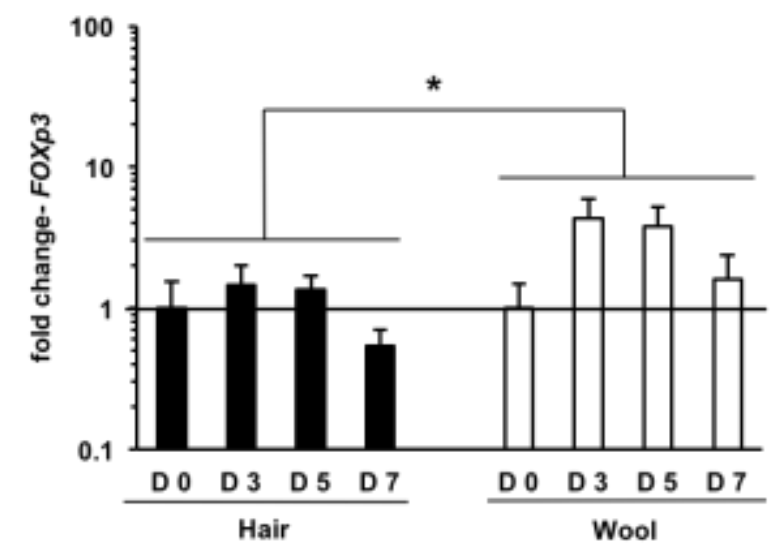

Figure 1. Expression of Forkhead Box P3 (FOXP3) in abomasal lymph nodes of lambs after $\boldsymbol{H}$. contortus infection.

Differential expression of FOXP3 in abomasal lymph nodes at $0,3,5$, and 7 days after infection in hair and wool lambs. Statistical analyses were based on log 2 of $\Delta \mathrm{Ct}$ values. Values in the figure were expressed as fold-changes relative to day 0 lambs of each breed. * denotes breed differences in $\Delta \mathrm{Ct}$ at $\mathrm{P}<0.05$. 

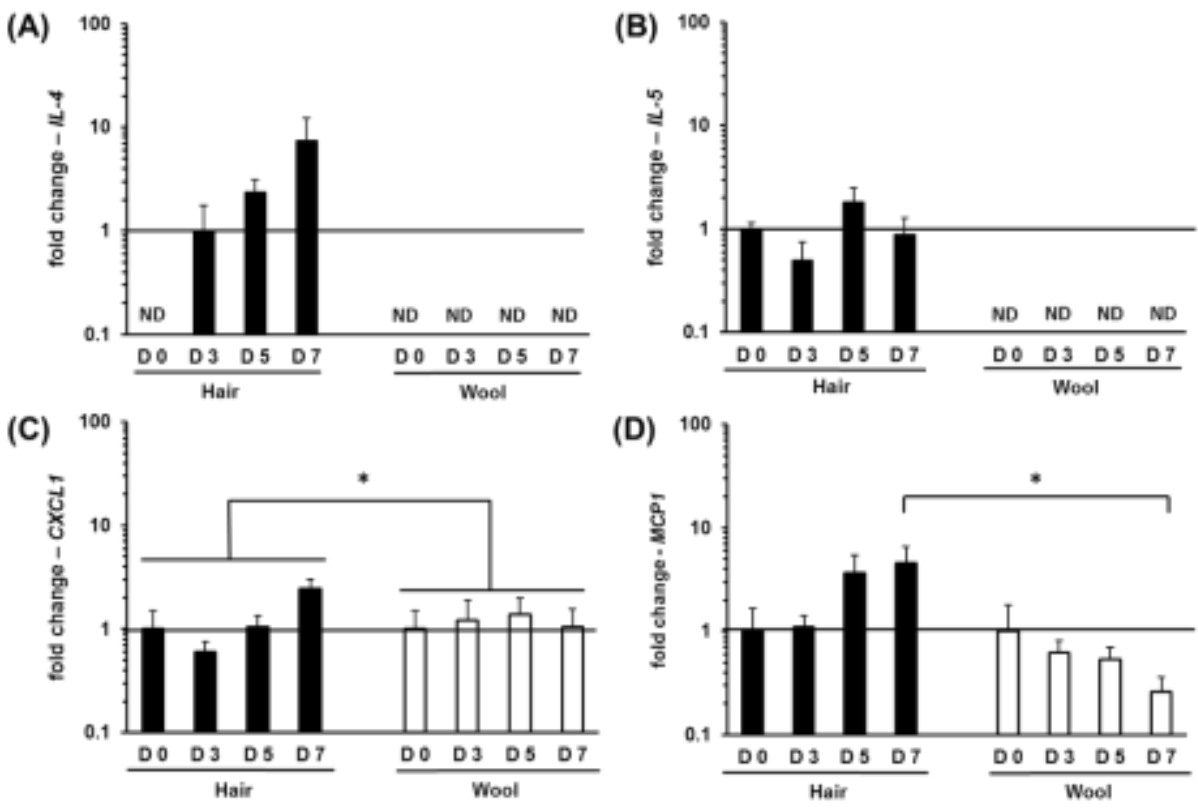

Figure 2. Analysis of gene expression in abomasal mucosa of lambs after infection with $H$. contortus.

Differential gene expression of IL-4 (A), IL-5 (B), CXCL1 (C), and MCP1 (D) in abomasal mucosa at $0,3,5$, and 7 days after infection in hair and wool lambs. Statistical analyses were based on log 2 of $\Delta \mathrm{Ct}$ values. Values in the figure were expressed as fold-changes relative to day 0 lambs of each breed. * denotes breed differences in $\Delta \mathrm{Ct}$ at $\mathrm{P}<0, .05$. ND indicates no detectable expression. 


\section{Tables}

Table 1: Primer sequences of candidate genes

\begin{tabular}{|c|c|c|c|c|c|c|}
\hline Gene Name & Abbr & Forward Primer $\left(5^{\prime}-3^{\prime}\right)$ & Reverse Primer $\left(5^{\prime}-3^{\prime}\right)$ & (bp) & Accession $\mathrm{H}$ & $\begin{array}{c}\mathrm{T}_{M} \\
\left({ }^{\circ} \mathrm{C}\right)\end{array}$ \\
\hline Annexin 3 & ANXA3 & ACAGAAACATCAGCCAGAGG & TCCTCGCACAACGAACTATG & 90 & XM_004009934.1 & 79 \\
\hline Arginase 1 & ARG1 & GTGAAGGAAGTGGAAAAGTAAGTGA & TGTAAGTTGGAGGAAAGGGAAA & 82 & BC105497 & 75 \\
\hline Chemokine Ligand 1 & $\mathrm{CXCl} 1$ & CCAGGCTAGTGCCAACTGAT & TGGGAGCCATTTGTTTCTCT & 102 & XM_004010090.1 & 78 \\
\hline Chemokine Receptor 3 & CXCR3 & GATGTGGGTGCTACTCATGC & TCTCGGACCAGGATGAATCT & 107 & XM_004022179.1 & 87 \\
\hline Complement protein 3 & $\mathrm{C} 3$ & GCACTGTCCACCAACCTCA & ATCAGGCTTCTGCTTCTCCA & 87 & XM_004022821.1 & 82 \\
\hline Forkhead Box P3 & FOXP3 & GAAACAGCACATTCCCAGAGT & GGATGAGGGTGGCATAGGT & 90 & FJ491732.1 & 80.5 \\
\hline Galectin 14 & GAL14 & CGGAGGAGAAGAAGATGCAG & CCTTGAACGAGGAGCTGTCT & 84 & NM_001009251.1 & 79 \\
\hline $\begin{array}{l}\text { Glyceraldehyde } 3 \text { - } \\
\text { phosphate } \\
\text { dehydrogenase }\end{array}$ & GAPDH & CAGGAGCACGAGAGGAAGAG & AATGTATGGAGGTCGGGAGA & 91 & HM043737 & 83 \\
\hline Interleukin 3 & IL-3 & GACACGACTTAGCAGCAGCA & GCTTCAGAGAGGGAACTAGGC & 94 & EU293838 & 78 \\
\hline Interleukin 4 & IL -4 & GCTGAACATCCTCACATCGAG & TTCTCAGTTGCGTTCTTTGG & 87 & AF172168.1 & 80 \\
\hline Interleukin 5 & IL-5 & CACTGCTCTCCACGCATCAA & TCATCAAGTTCCCATCACCTATCA & 50 & Ref (8) & 75 \\
\hline Interleukin 6 & IL-6 & TAACCACTCCAGCCACACAC & GATAACCTTTGCGTTCTTTACCC & 80 & NM_001009392.1 & 80 \\
\hline $\begin{array}{l}\text { Matrix } \\
\text { Metalloproteinase } 13\end{array}$ & MMP13 & TATGCTTCCTGACGATGACG & GGCGTTITCGGATGTTTAGA & 87 & GO221063.1 & 79 \\
\hline $\begin{array}{l}\text { Monocyte } \\
\text { Chemoattractant } \\
\text { Protein }\end{array}$ & MCP1 & GACAAACTACAGGAGGTGAATCTTG & TATCTGCGTGATGGGGATG & 87 & NM_001009472 & 76 \\
\hline $\begin{array}{l}\text { Peroxisome } \\
\text { Proliferator-Activated } \\
\text { Receptor } y\end{array}$ & PPARY & CTTGACGGGAAAGACGACA & GCTGATGTGCTTGAACTTGATT & 97 & NM_001100921.1 & 76 \\
\hline $\begin{array}{l}\text { Platelet-Derived } \\
\text { Growth Factor }\end{array}$ & PDGF & GACCACTCCATCCGTTCCT & TCCAATTCAGCTCCGTCTTC & 80 & NM_001009471.1 & 80 \\
\hline $\begin{array}{l}\text { Tumor Necrosis Factor } \\
\text { alpha }\end{array}$ & TNFa & GCCTTGGCTCAGATGTGTTT & MAGCAMAGGAGGCACAAAG & 90 & NM_001024860 & 81 \\
\hline $\begin{array}{l}\text { Vascular Endothelial } \\
\text { Growth Factor }\end{array}$ & VEGF & CGAAAGTCTGGAGTGTGTGC & TATGTGCTGGCTTTGGTGAG & 85 & AF071015.1 & 79 \\
\hline $\begin{array}{l}\text { Gamma-Delta T cell } \\
\text { Marker }\end{array}$ & WC.1 & ACAGCGGAAGTCTCAACACC & TCCAAGGGTCAGAAGGACAC & 120 & XM_004017139.1 & 82 \\
\hline
\end{tabular}


Table 2: Breed effect on gene expression in abomasal tissue

\begin{tabular}{|c|c|c|}
\hline Gene Name & Hair & Wool \\
\hline MCP1 & & ++ \\
\hline MMP13 & & +++ \\
\hline PDGF & & + \\
\hline TNFa & & ++ \\
\hline
\end{tabular}


Table 3: Breed effect on gene expression in abomasal mucosa

\begin{tabular}{l|c|c}
\hline Gene Name & Hair & Wool \\
\hline ANXA3 & & ++ \\
ARG1 & + & \\
GAL14 & + & \\
PPARY & & + \\
VEGF & & ++ \\
IL-3 & & ++ \\
IL-6 & & ++ \\
TNF $\alpha$ & & ++ \\
CXCR3 & & ++ \\
WC.1 & + \\
C3 & ++ \\
\hline \multicolumn{2}{l|}{$P<0.05 ;++P<0.01 ;+++P<0.001$}
\end{tabular}


Table 4: LS Means for serum IL-4 (pg/mL) production after $\boldsymbol{H}$. contortus infection

\begin{tabular}{lcccc}
\hline & \multicolumn{4}{c}{ Day After Infection } \\
\cline { 2 - 5 } & $\mathbf{0}$ & $\mathbf{3}$ & $\mathbf{5}$ & $\mathbf{7}$ \\
\hline Hair & $171.3^{\mathrm{A}}$ & $77.7^{\mathrm{B}}$ & $88.2^{\mathrm{B}}$ & $164.4^{\mathrm{A}}$ \\
Wool & $185.7^{\mathrm{A}}$ & $94.7^{\mathrm{C}}$ & $112.9^{\mathrm{B}, \mathrm{C}}$ & $129.2^{\mathrm{B}}$ \\
\hline $\begin{array}{l}P \text {-value } \\
\text { breed*day }\end{array}$ & 0.155 & 0.097 & $\mathbf{0 . 0 2 1}$ & $\mathbf{0 . 0 0 2}$ \\
\hline
\end{tabular}

SEM of LS means $=6.8 \mathrm{pg} / \mathrm{ml}$

LS means within a row with different superscripts differ $(P<0.05)$ 